\title{
Trends in Worker Displacement Penalties in Japan: 1991-2005
}

\author{
Michael Bognanno* and Ryo Kambayashi**
}

Draft: May 2009

\begin{abstract}
We examine the period from 1991 to 2005 to document the effects of a changing Japanese labor market on trends in the cost of job change. During this period, job change penalties and the extent to which they were age related grew. Evidence is also found of a diminishing specificity in human capital in industry for job changers in the Japanese labor market. While penalties from changing industries were diminishing, career change penalties grew.
\end{abstract}

Theme: Microeconomics of unemployment

Keywords: Displacement

JEL Classification: J31, J41, J63, J6

*Temple University - Department of Economics; IZA

869 Ritter Annex (004-00), 1301 Cecil B. Moore Ave., Philadelphia, PA 19122, USA

E-mail: bognanno@temple.edu

**Institute of Economic Research, Hitotsubashi University

2-1 Naka, Kunitachi, Tokyo, 186-8603, JAPAN

E-mail: kambayas@,ier.hit-u.ac.jp 


\section{Introduction}

The labor market adjustment to the economic stagnation in Japan during the 1990s included a clear trend towards more involuntary separations in the labor market, erosion in the earnings of newly hired workers relative to incumbent workers and job change costs that became more severe with age. This paper documents the trends in the cost of job change in Japan between 1991 and 2005 using data from the Employment Trend Survey micro-survey conducted by the Ministry of Health, Labor and Welfare. The findings may be insightful for other countries with strong internal labor markets facing a long period of economic stagnation.

Computed from publically available data, the reasons for involuntary job separation during the period are provided in figure $1 .{ }^{1}$ The turnover rate is defined by the annual number of separations for each reason divided by the number of employees at the beginning of the year. The calculation is only for regular workers, defined as those who have been on the job at least a month or have an open-ended employment contract. The involuntary turnover rate, the sum of the reasons for separation in the table, peaked at $6.3 \%$ in 2002 , nearly double its rate in 1991. This peak coincided with the peak in unemployment of 5.5\%. The primary source of involuntary job separation growth was layoffs due to management convenience (from $0.7 \%$ in 1991 to $2.0 \%$ in 2002). Increasing trends in contract expiration and dismissals as a source of involuntary separation are also evident.

\footnotetext{
${ }^{1}$ The statistics presented in figure 1 are not tabulated from the inflow supplement of Employment Trend Survey data. They come from a government website that classifies the reasons for job separation differently. (Source: http://wwwdbtk.mhlw.go.jp/toukei/kouhyo/data-rou14/jikei/kd-jikeiretu-13.xls)
} 
Figure 1: The Turnover Rate by Reasons of Involuntary Separation (1991-2005)

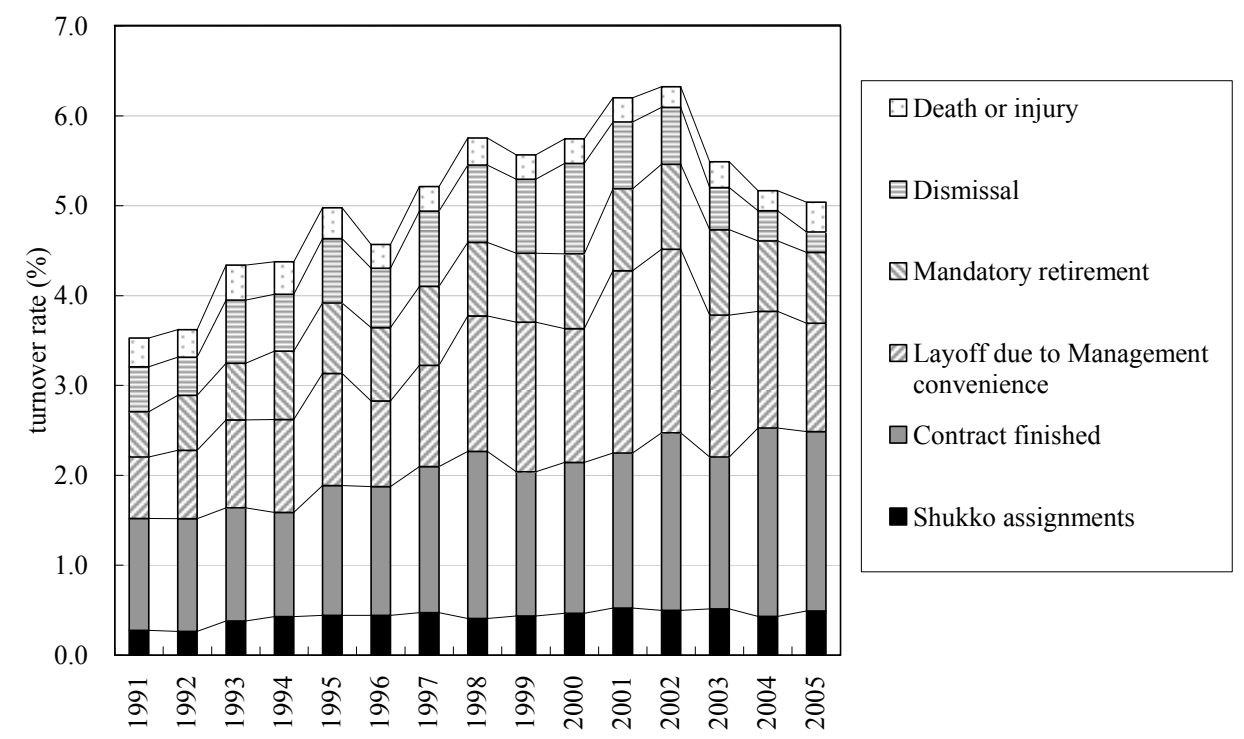

The labor market adjustment to economic conditions occurred not only in the quantity of labor demanded but also in the price. Figure 2 displays the mean of wages changes by the year and reason for job separation, as well as the unemployment rate. ${ }^{2}$ As expected, involuntary job separations carried the largest wage cost and voluntary the least. It is also evident that the wage outcomes for all three sources of job separation were worsening during the 1990s. For involuntary job separation, the wage loss grew from 3.3\% in 1991 to $8.1 \%$ in 1999 . The wage change for voluntary separation fell from $3.9 \%$ in 1991 to $-0.4 \%$ in 1999 . The two series are highly correlated (0.91) despite their level difference during this period. It is interesting to note that the trend towards larger wage losses ended while unemployment was still rising. From 1991

\footnotetext{
${ }^{2}$ Source: Calculated from the Employment Trend Survey Micro Data. In these data, wages are a categorical variable. In computing tables 2 and 3, we assign the following values to the categories: wage declines of $30 \%$ or more are assign $-30 \%$, wage declines of 10 to $30 \%$ are assigned $-15 \%$, wage changes of $+10 \%$ to $-10 \%$ are assign $0 \%$, wage increases of 10 to $30 \%$ are assigned $+15 \%$, and wage increases over $30 \%$ are assigned $+30 \%$. This assignment follows the work of Abe et al.
} 
to 1999 , both voluntary and involuntary wage changes series were highly correlated with the unemployment, -0.97 and -0.94 respectively. After 2000, while the correlation remains high, it loses statistical significance.

Figure 2: Mean of Wage Change by Year (1991-2005)

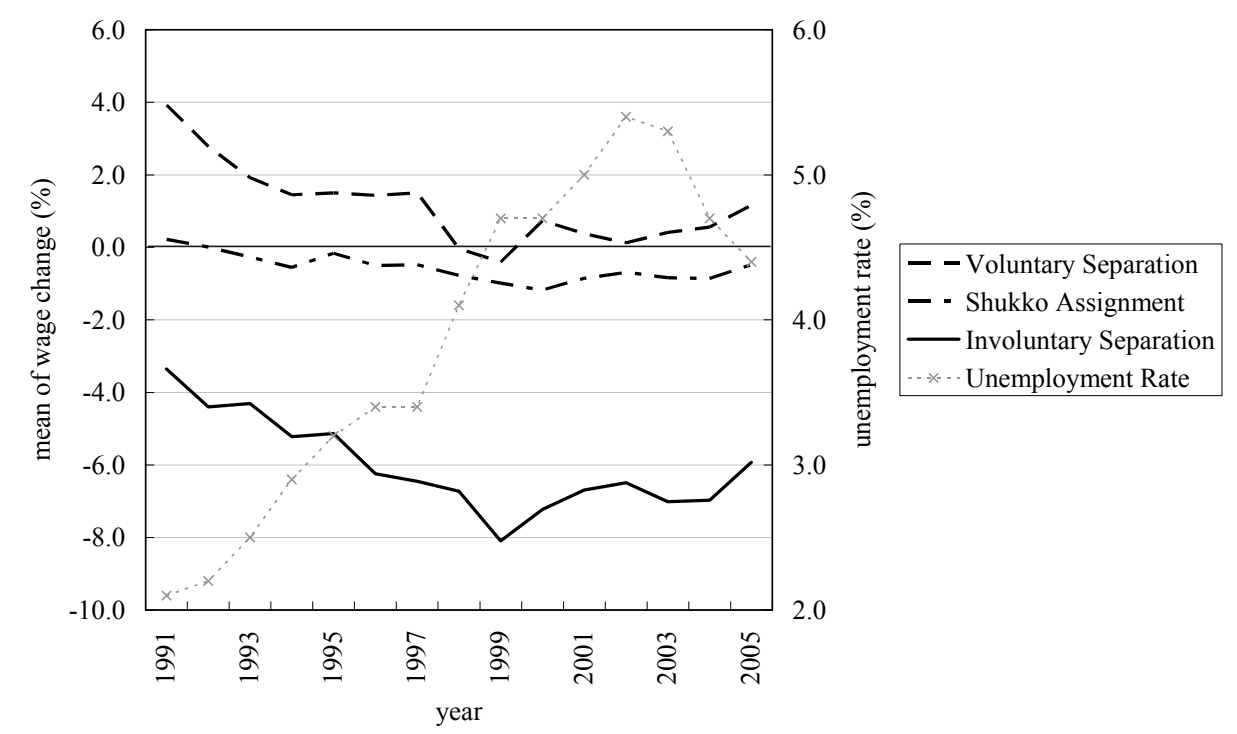

Section 2 of the paper introduces the literature on job displacement penalties and

Section 3 describes the data and classifies job changes into voluntary and involuntary. Section 4 provides estimates of an ordered logit model to examine multiple factors influencing job change penalties and more clearly identify trends. Section 5 considers possible explanations for increasing job change penalties and the diminishing return to age in the labor market for workers finding new employment. Section 6 provides a comparison between job change penalties in Japan and the U.S. during the 1990s. Conclusions follow in section 7.

\section{Studies on Job Displacement Penalties}

Numerous studies have investigated job displacement penalties in the US labor market. Surveys of this literature were conducted by Hamermesh (1989), Fallick (1996) and Farber (1997). 
Estimates of US job displacement penalties are in the range of 15 to $40 \%$ (Topel 1993). Larger penalties are associated with more firm and labor market experience, periods of higher unemployment and changing industry upon re-employment. Both Ruhm (1991) and Jacobsen, LaLonde and Sullivan (1993) found evidence of earnings reductions for displaced workers that persisted years after job separation. Jacobsen at al. also found that the earning loses from job displacement for workers leaving distressed firms began prior to job separation and were little influenced by changes in firm size, industry, local labor market conditions, gender or age. Though finding that age had little influence on earnings losses, large losses existed for high tenure workers.

Studies of job change penalties in the Japanese labor market are scarce. Since the comprehensive study by Abe, Higuchi, Nakamura, Kuhn and Sweetman (2002) using Employment Trend Survey data from 1995, there has been no research with nationally representative data to establish how changes taking place in the Japanese labor market have affected the wage implications of job change. Abe et al. studied the effects of job change on wages during a period of moderate GDP growth (2.4\%) and unemployment (3.2\%) and find that, when all sources of job separation both voluntary and involuntary are grouped together, on average male and female workers benefited slightly from job change. For both genders, the consequence of job change was an increase in income of about $2.2 \%$. When only involuntary job changes are considered and those transferred temporarily to other companies are excluded (the practice of shukko), the average male lost $4.3 \%{ }^{3}$ The mean loss for men results from the losses

\footnotetext{
${ }^{3}$ Using data from 2000 through 2003, Bognanno and Delgado (2005) find much larger job displacement penalties in Japan than Abe et al. They also find evidence of job displacement penalties that are strongly age-related, suggesting severe consequences for older workers losing jobs in the primary sector. However, their data includes only workers successfully re-employed through the services of a job placement firm. Because of the specialized sample, the generality of their results is unknown. A study with nationally representative data is necessary to substantiate
} 
of men 45 and over more than offsetting the gains of younger men. Nearly $28 \%$ of men 45 and over suffered wage losses of more than $30 \%$. Abe at al. attribute the large losses for men over 55 to the traditional practice of mandatory retirement in Japan, followed by low paid or part-time work after mandatory retirement. Large wage reductions for older female job changers are much less frequent. This is suggested by Abe et al. to result because females are less often subject to mandatory retirement.

For greater job displacement penalties for older workers theory offers several explanations. Four potential sources of job displacement penalties include the loss of specific human capital, the loss of a superior job match, the loss of possible union or industry wage premiums, and the loss of seniority (Fallick 1996). If specific human capital, job match quality and wage premiums are increasing in job tenure, older workers should have greater losses upon job displacement. Regarding specific human capital, Koike (1988) has stressed the significance of on the job training in Japan and Rebick (2005) notes that, in contrast to formal education, on the job training is harder for employees to convey to a new employer, thus making employment change more costly.

Another explanation for greater job displacement penalties for older workers follows Lazear's (1979) model of delayed payment contracts. It offers both an explanation of the institution of mandatory retirement and of why mandatory retirement might be followed by large wage losses for older workers with greater tenure. Workers in the model are motivated by a contract that pays them below their marginal product early in their firm tenure and more than their marginal product later. Worker motivation derives from the incentive to remain with the firm in order to collect the premium at the end of the contract. Workers separated from their 
firms late in their tenure, lose the amount that they earn above their marginal product when they face the outside labor market. Mandatory retirement in the model is a device to protect the firm from employees wishing to collect wages exceeding their marginal products beyond the anticipated retirement date.

Lazear's model may be particularly applicable in explaining large job displacement penalties for older workers in the Japanese labor market. First, mandatory retirement is both legal and prevalent (Clark and Ogawa, 1992). As of 2002, almost all firms had mandatory retirement (JILPT, 2005, p.53, Table 3-27). Furthermore, workers reemployed by their firm after mandatory retirement typically take wage reductions of 50-70\% (Rebick, 2005). That workers accept such reductions indicates that they have little opportunity to maintain their prior earnings level in the outside labor market and lends credibility to the notion that they were receiving wages in excess of their marginal products prior to mandatory retirement. Second, relative to the US and the OECD, firm tenure in Japan is longer (Hashimoto and Raisian, 1985), especially for men (Rebick, 2005). Long tenure provides a basis from which delayed payment contracts are feasible. Third, consistent with delayed payment contracts, Clark and Ogawa (1992) found that earnings profiles were steeper in firms with earlier ages of mandatory retirement. Last, Japanese firms provide workers a substantial payment upon retirement. This payment in itself constitutes one form of delayed compensation. The amount of this payment is heavily reduced should separation occur for workers with little tenure, for workers who voluntarily quit or for workers who are dismissed. $^{4}$

\footnotetext{
${ }^{4}$ On average, a worker with 40 years of firm tenure receives 27.3 times as much as a worker with three years of tenure (Statistics and Information Department, 2003).
} 


\section{The Employment Trend Survey Micro Data: 1991-2005}

The Ministry of Health, Labor and Welfare has been conducting the Employment Trend Survey since 1964. The purpose of the survey is to observe labor mobility between regions, industries, establishment sizes and occupations. The survey encompasses 14,000 establishments with five or more regular employees sampled from almost all industries. ${ }^{5}$ Following Abe et al., because the labor mobility in the public sector is so different from that in private sector, public sector employees have been deleted from the sample analyzed. We use the Employment Trend Survey micro-data with the permission of the Economic and Social Research Institute.

An average of 83,316 newly hired workers per year were sampled in the establishments surveyed in the years from 1991 to 2005 . We focus on the job changers within all of newly hired workers, because others do not have information about their previous employment and the wage changes resulting from job change. ${ }^{6}$ From the overall sample of newly hired workers from 1991 to 2005 , totaling $1,249,735$ workers, 661,560 are job changers (52.9\%). From this group, 562,844 job changers have relatively complete information and are used in this analysis.

Two variables key in the survey are the wage change present upon reemployment and the cause of job separation. The survey collects the wage change by categorizing them as a loss of $30 \%$ or greater, a loss of $10 \%$ to $30 \%$, between a $10 \%$ loss and a $10 \%$ gain, a gain of $10 \%$ to $30 \%$ and a gain of $30 \%$ or more.

Apart from shukko assignments, the cause of job separation in these data is classified into one of eight categories: (1) job dissatisfaction; (2) bad human relations in the firm; (3) concern over the future of firm; (4) dissatisfaction over compensation; (5) dissatisfaction with

\footnotetext{
${ }^{5}$ ETS excludes agriculture, forestry and fisheries, domestic services, educational services, and services by foreign governments and international agencies. Since 2003, educational services were included in the Employment Trend Survey. However, for consistency with prior years, we excluded this industry.

${ }^{6}$ Others include school leavers (graduates in the survey year) and unemployed/inexperienced (those having been unemployed more than one year or those in their first job).
} 
working time and/or number of holidays; (6) marriage, maternity or family care; (7) dismissal or mandatory retirement; (8) other. We divide these categories into either voluntary or involuntary job separations. Categories $1-6$ and 8 denote job separations initiated by the workers and are deemed "voluntary." Separations resulting from dismissal or mandatory retirement are coded as "involuntary." Reasons for dismissal include plant closings, layoffs and worker misconduct.

Our distinction between voluntary and involuntary job change differs somewhat from the job displacement literature. This is due to the aggregation of the job separation causes in the category of "dismissal or mandatory retirement." The literature classifies involuntary job separations as being due to mass layoffs and plant closures but not to firings for cause (Kletzer 1998). In our data we are unable to separate out workers dismissed for misconduct from those dismissed due to plant closings and layoffs. In fact, in actual Japanese labor disputes, these two reasons are used interchangeably (Kambayashi et al. (2008b)). Mandatory retirement is not a feature of the U.S. labor market, except for a few specific occupations, and is not considered in the literature. ${ }^{7}$ In regards to the inclusion of those subject to mandatory retirement, workers in these data losing their jobs for this reason fit within the notion of job displacement because they found re-employment and, hence, would presumably have remained in their prior job if allowed. It is worth noting that workers subject to mandatory retirement in Japan included those under the age of 60 at a significant share of firms in the 1990s, some years earlier than what might be considered a typical retirement age. ${ }^{8}$

\footnotetext{
${ }^{7}$ Mandatory retirement in the U.S. prior to the age of 70 was outlawed in 1978 and banned at any age in 1986. Mandatory retirement is not prohibited for law enforcement officers, corrections officers, firefighters, air traffic controllers or commercial airline pilots.

${ }^{8}$ The age of mandatory retirement varied across industry and time. Despite the legal invalidation of mandatory retirement prior to the age of sixty in 1994, the decline in firms with a mandatory retirement age below sixty adjusted gradually. The ratio of firms with a mandatory retirement age less than 60 according to the annual Employment Administration Survey (Koyo-kanri Chosa) is as follows: 36.1\% in 1991; 29.2\% in 1992; $23.4 \%$ in $1993 ; 20.0 \%$ in $1994 ; 15.9 \%$ in $1995 ; 14.2 \%$ in $1996 ; 11.7 \%$ in $1997 ; 9.8 \%$ in $1998 ; 6.7 \%$ in $1999 ; 0.8 \%$ in 2000 ; $0.8 \%$ in $2001 ; 1.0 \%$ in 2002 .
} 
In evaluating the cost of job change, we regard the wage change due to shukko (temporary transfer to another company while preserving the employment contract) as a bench mark. The transfer of employees to associated companies or subsidiaries is a common practice among Japanese firms. The main purpose of shukko assignments is to give the worker an opportunity to gain exposure to the business practices at allied companies in the interest of the worker's long-term career development.

The fraction of turnover due to this source of job change varied little through our period of examination. Figure 1 shows turnover rates induced by shukko to be stable at about $0.4 \%$ since 1994 . The contrast between the stability in the rate of shukko and the volatility in voluntary/involuntary separations is found not only in turnover rate but also in the job change penalties. Figure 2 indicates that those who were assigned to shukko did not experience large wages losses, at its bottom in 2000 , shukko assignments resulted in only a $1.2 \%$ wage loss, nor was there a strong trend in wage change during the period.

Since workers subject to skukko remain in continuous employment, they provide a proxy for how wages changed within the firm in general. Considering that the Japanese economy had experienced deflation and zero growth beginning in 1992, it is not unusually that the average wage change with shukko assignments was only slightly negative.

As for the other variables in the data, almost every variable is categorical; for example age is provided in seven five-year increments and including those 19 or less and 65 or more to form nine categories in total. Present firm size is divided into five categories $(5-29,30-99,100$ 299, 300-999, 1000+). Previous firm size is divided into seven categories (public organization, 14, 5-29, 30-99, 100-299, 300-999, 1000+). Education is divided into four categories by graduation level (junior high, high school, junior college, university). 
Appendix 1 provides sample means for the variables used in this analysis. Of job changers in the sample, $40 \%$ are female, $17 \%$ and $12 \%$ are subject to involuntary job change and shukko assignment respectively. Defining career change as a change of both industry and occupation, $26 \%$ of workers change careers, while $25 \%$ change only in industry and $7 \%$ change only in occupation. In terms of working hours, $12 \%$ of workers are part-time both before and after job change, $7 \%$ move from part-time to full-time and $7 \%$ move from full-time to part-time. While $71 \%$ of job changers move to a firm in a different size category, only $17 \%$ move to smaller firms; this is partly because ETS excludes small firms under 5 regular employees.

\section{Factors Influencing the Cost of Job Change: Empirical Estimates}

According to the literature introduced in section 2, one of the most important factors to affect job change penalties is age and gender. It is worthwhile to confirm this conventional wisdom in our data. In the next two figures, we depict the transition of mean of job change penalties by age and gender. Along with the discussion in the previous section, we show the relative magnitude of mean of wage change compared with shukko assignments.

Figure 3: Mean of Wage Change by Gender and Age (under 19 to over 65)

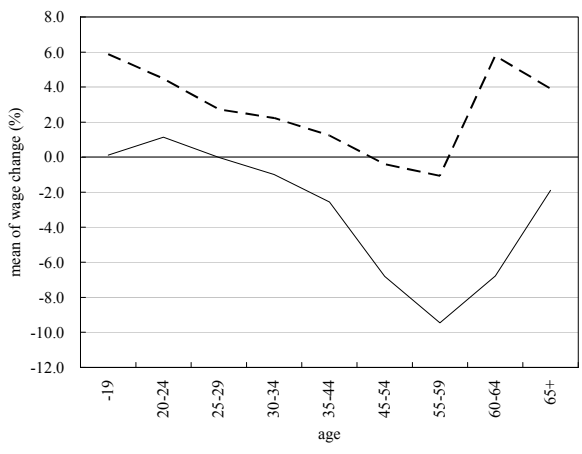

(A) Male

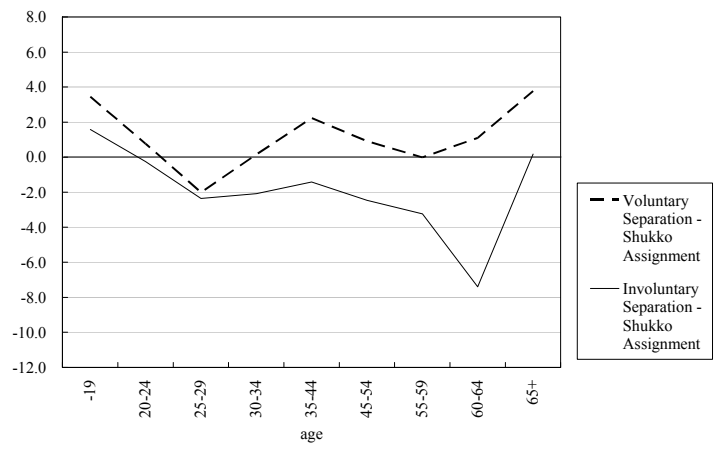

(B) Female 
Panel (A) and (B) of figure 3 show that older workers tend to face larger job change costs, but more so for males than for females. Large negative wage changes are more likely for older males than older females, especially in the involuntary job separation sample. The potential impact of mandatory retirement for older workers appears significant for both genders but more so for males. Comparing the results over the whole sample period to those of Abe et al. (2002) with 1995 data, the mean job displacement penalty for men undergoing involuntary job change, a wage loss of $9.3 \%$, is double the 1995 estimate, while for women wages fell $3.4 \%$ compared to a wage gain of $0.3 \%$ in 1995 .

In order to examine the factors that may influence job change penalties in a richer framework than is possible with the summary statistics presented in previous section, we estimate an ordered logit model. The dependent variable in this study, wage change, is provided by the Employment Trend Survey as one of five ordered outcomes. To cope with this, we estimate an ordered logit model and define wage loss $_{\boldsymbol{i}}$ to represent the observed percentage wage change for worker $i$.

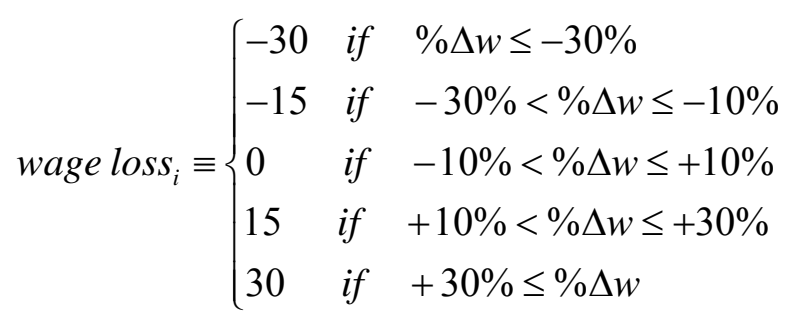

Presented as a latent variable model and defining wage loss $_{i}{ }^{*}$ as a latent variable, the model is then

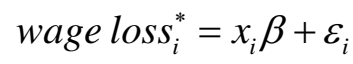

and 


$$
\begin{aligned}
\text { wage }_{\text {loss }}=k \quad \text { if } \quad & \tau_{k}<\text { wage loss } \\
i & \leq \tau_{k+15} \\
& \left(k=-30,-15,0,+15,+30, \quad \text { and } \tau_{-30}=-\infty, \tau_{45}=\infty,\right)
\end{aligned}
$$

where wage loss $_{i} *$ denotes the unobserved ordinal percentage change in the wage for individual $i$, $\boldsymbol{x}_{\boldsymbol{i}}$ is a vector of indicator variables for worker characteristics and the characteristics of the worker's initial and subsequent firms and $\varepsilon$ is a random error term assumed to have a logistic distribution. By using estimates coefficients and the logistic distribution function denoted as $\boldsymbol{F}$, the probability that a person with $\boldsymbol{x}_{\boldsymbol{i}}$ experiences a $\boldsymbol{k} \%$ wage change can be calculated as follows:

$$
\begin{aligned}
\operatorname{Pr}\left[{\text { wage } \left.\text { loss }_{i}^{*}=k \mid x_{i}\right]}=\operatorname{Pr}\left[\hat{\tau}_{k}<x_{i} \hat{\beta}+\varepsilon_{i} \leq \hat{\tau}_{k+15}\right]\right. \\
=F\left(\hat{\tau}_{k+15}-x_{i} \hat{\beta}\right)-F\left(\hat{\tau}_{k}-x_{i} \hat{\beta}\right) \\
\quad\left(k=-30,-15,0,+15,+30, \text { and } \hat{\tau}_{-30}=-\infty, \hat{\tau}_{45}=\infty,\right)
\end{aligned}
$$

\subsection{Age Effects}

We first estimate an ordered logit model year by year (from 1991 to 2005) and by reason for job separation (voluntary, involuntary, shukko assignments) to examine the effect of age. The specifications estimate the effects of individual characteristics (age, age squared, gender and education level), and job characteristics in the present job (firm size, industry and occupation) on the cost of job change. To consider whether human capital is industry, occupation or career specific, we code three variables for workers changing (1) only in industry, (2) only in occupation and (3) in career. A career change constitutes a change of both industry and occupation. The next table presents a summary of estimated coefficients in regards to age with just sign and significance denoted. The full estimates appear in Appendix 2. 
Table 1a: Summary of Ordered Logit Estimation (Age Effect)

\begin{tabular}{|c|c|c|c|c|c|c|c|c|c|c|c|c|c|c|c|}
\hline & (1) & (2) & (3) & (4) & (5) & (6) & (7) & (8) & (9) & (10) & (11) & (12) & (13) & (14) & (15) \\
\hline Data & 1991 & 1992 & 1993 & 1994 & 1995 & 1996 & 1997 & 1998 & 1999 & 2000 & 2001 & 2002 & 2003 & 2004 & 2005 \\
\hline Age & 0 & 0 & 0 & $+^{* *}$ & 0 & 0 & 0 & 0 & $++^{* * *}$ & $+^{*}$ & $+^{* * *}$ & 0 & 0 & 0 & $++^{*}$ \\
\hline $\mathrm{Age}^{2}$ & 0 & $-{ }^{* *}$ & $-{ }^{* *}$ & $-{ }^{* * *}$ & $-{ }^{* * *}$ & $-{ }^{*}$ & $-{ }^{* * *}$ & $-{ }^{* * *}$ & $-{ }^{* * *}$ & $-{ }^{* * s}$ & $-{ }^{* * *}$ & $-^{* * *}$ & $-^{* * * *}$ & $-{ }^{* * *}$ & $-{ }^{* * s}$ \\
\hline Observations & 4463 & 4256 & 4397 & 4010 & 5248 & 4928 & 4806 & 5238 & 5616 & 7002 & 7759 & 9650 & 10064 & 8640 & 8583 \\
\hline
\end{tabular}

\begin{tabular}{|c|c|c|c|c|c|c|c|c|c|c|c|c|c|c|c|}
\hline Data & $\begin{array}{c}(16) \\
1991\end{array}$ & $\begin{array}{l}(17) \\
1992\end{array}$ & $\begin{array}{l}(18) \\
1993\end{array}$ & $\begin{array}{c}(19) \\
1994\end{array}$ & $\begin{array}{l}(20) \\
1995\end{array}$ & $\begin{array}{l}(21) \\
1996\end{array}$ & $\begin{array}{c}(22) \\
1997\end{array}$ & $\begin{array}{c}(23) \\
1998\end{array}$ & $\begin{array}{l}\text { (24) } \\
1999\end{array}$ & $\begin{array}{c}(25) \\
2000\end{array}$ & $\begin{array}{l}(26) \\
2001\end{array}$ & $\begin{array}{l}(27) \\
2002\end{array}$ & $\begin{array}{c}(28) \\
2003\end{array}$ & $\begin{array}{c}(29) \\
2004\end{array}$ & $\begin{array}{c}(30) \\
2005\end{array}$ \\
\hline Age & $+^{* * *}$ & $+^{* *}$ & 0 & 0 & 0 & $--^{*}$ & 0 & $-{ }^{* * *}$ & $-{ }^{* *}$ & $-{ }^{*}$ & 0 & $--^{*}$ & 0 & $-{ }^{*}$ & $-{ }^{*}$ \\
\hline $\mathrm{Age}^{2}$ & $-{ }^{* * *}$ & $-{ }^{* * *}$ & $-{ }^{* * *}$ & $-{ }^{* * *}$ & $-{ }^{*}$ & 0 & $-{ }^{* * *}$ & 0 & 0 & 0 & $-{ }^{* *}$ & 0 & $-{ }^{* * *}$ & 0 & 0 \\
\hline Observations & 38614 & 31167 & 23763 & 21279 & 23321 & 28218 & 32418 & 26306 & 23151 & 26711 & 25591 & 21960 & 24675 & 25917 & 27556 \\
\hline
\end{tabular}

Shukko Assignment Sample

\begin{tabular}{|c|c|c|c|c|c|c|c|c|c|c|c|c|c|c|c|}
\hline & & & & & & & & & & & & & & & \\
\hline Data & 1991 & (J2) & (J) & (14) & (J) & (30) & (J) & (38) & (39) & (40) & (41) & (4z) & (43) & (44) & (45) \\
\hline Age & & $\frac{192}{* * *}$ & $4^{* * *}$ & $\frac{1994}{* * *}$ & $\frac{1995}{* * *}$ & 1996 & $\frac{1991}{* * 5}$ & $\frac{1998}{* * *}$ & 1999 & 2000 & 2001 & 2002 & 2003 & 2004 & 2005 \\
\hline $\mathrm{Age}^{2}$ & $\top$ & + & & $* * *$ & & $\top_{* * *}$ & + & + & + & + & ${ }^{+} * * *$ & $+\ldots$ & + & + & + \\
\hline $\mathrm{Age}^{\mathrm{E}}$ & - & - & - & - & - & - & $-\cdots$ & $-\cdots$ & - & - & - & $-\cdots$ & $-\cdots$ & $-\cdots$ & $-{ }^{+\infty}$ \\
\hline Observations & 2483 & 3145 & 3304 & 4327 & 4841 & 5020 & 4828 & 4526 & 4141 & 4629 & 5070 & 4446 & 5059 & 4110 & 4547 \\
\hline
\end{tabular}

Wage changes are mainly negative across the three panels in $\mathrm{Age}^{2}$ and zero or positive in Age. This provides for concavity in the age/wage change profile. Significant negative coefficients in the second order term imply a disproportionately larger penalty for older cohorts. For involuntary/voluntary sample, sometimes the concavity is weakened and coefficients become monotonically negative. On the other hand, the concavity of job changers by shukko assignments is robust through 15 years.

The nonlinearity of logit model makes it difficult to evaluate the magnitude of coefficient estimates for age. To gain insight into the magnitudes, we impute the effect of age on the probability for each wage change category $\boldsymbol{k}$ while equalizing the other explanatory variables to the sample mean. For example, let $\boldsymbol{y}_{\boldsymbol{i}}$ be the partial set of explanatory variables with effects that are under consideration, and $\mathbf{z}_{\boldsymbol{i}}$ be other explanatory variables $\left(\tilde{z}_{i}\right.$ is the mean of pooled sample). For each estimate of separation reason $\boldsymbol{j}$ in year $\boldsymbol{t}$, (2) becomes

$$
\begin{aligned}
& \text { wage } \operatorname{loss}_{i}^{j t *}=y_{i} \beta_{1}^{j t}+z_{i} \beta_{2}^{j t}+\varepsilon_{i}^{j t} \\
& \text { ( } j=\text { voluntary, involuntary, shukko; } t=1991, \cdots, 2005)
\end{aligned}
$$

The probability to be imputed is 
(6)

$$
\begin{aligned}
& P_{k}^{j t}\left(y_{i}\right) \equiv \operatorname{Pr}\left[\text { wage } \operatorname{loss}_{i}^{j t *}=k \mid y_{i}, \tilde{z}_{i}^{t}\right] \\
& =F\left(\hat{\tau}_{k+15}^{j t}-y_{i} \hat{\beta}_{1}^{j t}-\tilde{z}_{i}^{t} \hat{\beta}_{2}^{j t}\right)-F\left(\hat{\tau}_{k}^{j t}-y_{i} \hat{\beta}_{1}^{j t}-\tilde{z}_{i}^{t} \hat{\beta}_{2}^{j t}\right) \\
& \left(k=-30,-15,0,+15,+30, \quad \text { and } \hat{\tau}_{-30}=-\infty, \hat{\tau}_{45}=\infty,\right)
\end{aligned}
$$

The next figures depict the change in the probability of being represented in each wage change category as a function of age in 1993 for the average person in the pooled sample. The figures present the results for both voluntary and involuntary separations in comparison to those with shukko assignments; that is, $\boldsymbol{P}_{\mathbf{k}}^{j, 1993}(\mathbf{a g e})-\boldsymbol{P}_{\mathbf{k}}^{\text {shukko,1993 }}(\mathbf{a g e})(\mathrm{j}=$ voluntary, involuntary; age $=18, \ldots$, $65)$.

Figure 4: Estimated Relative Probability of Wage Change by Age 1993

(A) under $-30 \%(k=-30)$

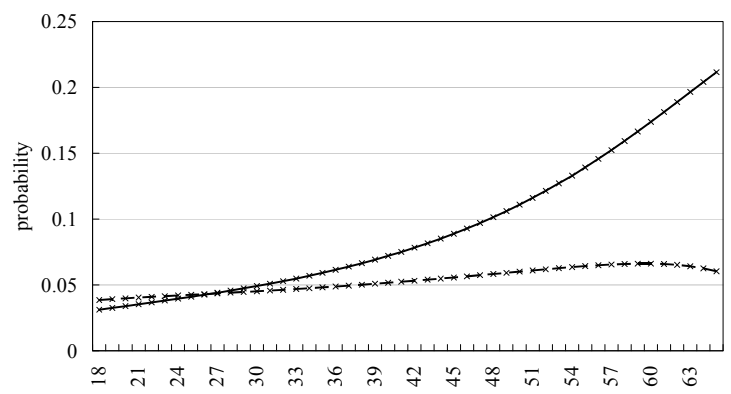

(C) from $-10 \%$ to $+10 \%(k=0)$

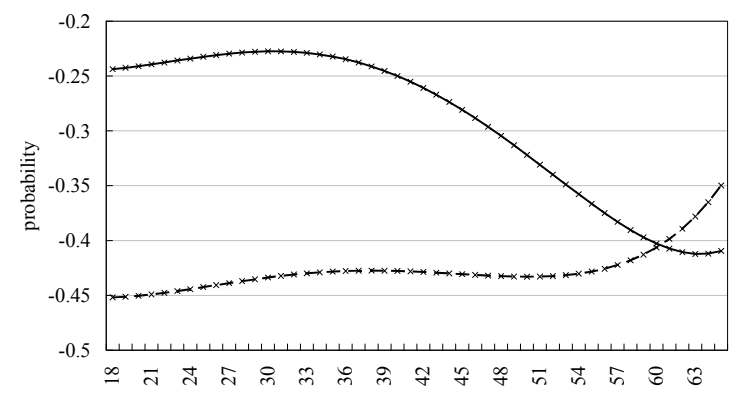

(B) from $-30 \%$ to $-10 \%(k=-15)$

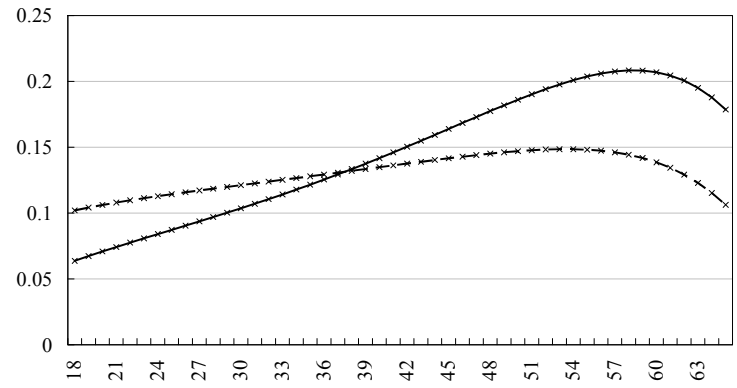

(D) from $+10 \%$ to $+30 \%(k=15)$

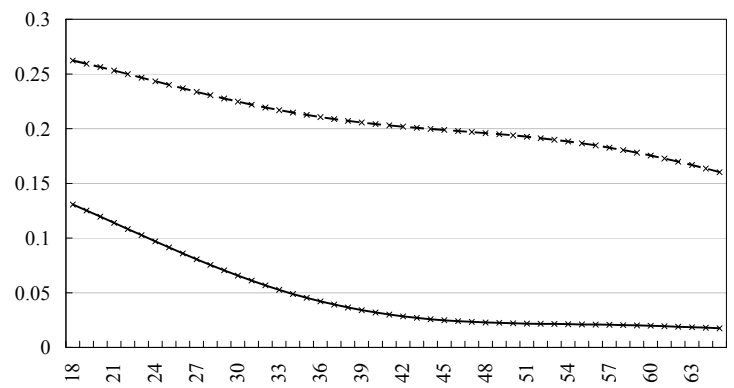




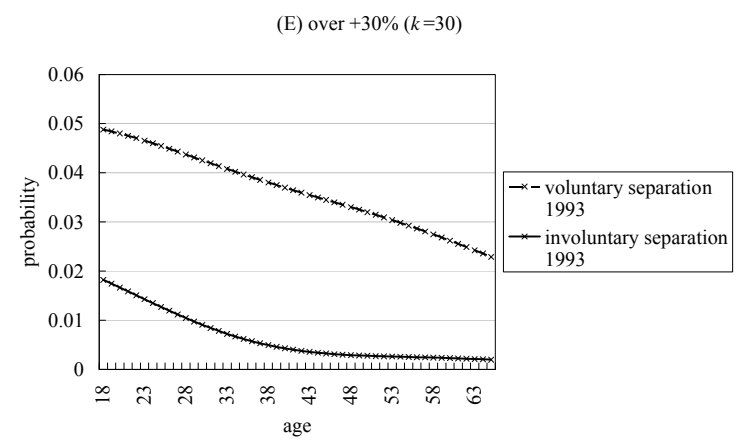

According to panel A, if voluntary and involuntary job changers are 18 and other attributes are equal to the mean of pooled sample, they experience a $30 \%$ wage decline with the probability of about 0.039 and 0.031 respectively. For involuntary job changers, the probability rises strongly after age 35 to 0.211 at age 65 . As for voluntary separations, the relative likelihood of $30 \%$ drop in wages does not grow much with age. It stands at 0.060 at age 65 . Considering the previous discussion of shukko assignment as a bench mark, ageing did not increase the job change cost for voluntary job changers in panel A. Both involuntary and voluntary job changers increased in their likelihood of falling into the moderate wage loss category in panel B, though the probability diminishes in the 60 s. In terms of the wage gains in panels D and E, increases in age reduce the probabilities for both voluntary and involuntary job changers. Taken as a whole, worse wage change outcomes befall older job changers. As these panels were produced to represent the relationships in 1993, we need further analysis to determine how the patterns changed with time during the 1990s.

Figures 4 and 5 are similarly constructed. However, figure 5a depicts the results for only involuntary separations and at five points in time: 1993, 1996, 1999, 2002 and 2005. 
Figure 5a: Estimated Probability of Wage Change by Age

Relatively Evaluated Involuntary Separation 1993, 1996, 1999, 2002, 2005

(A) under $-30 \%(k=-30$

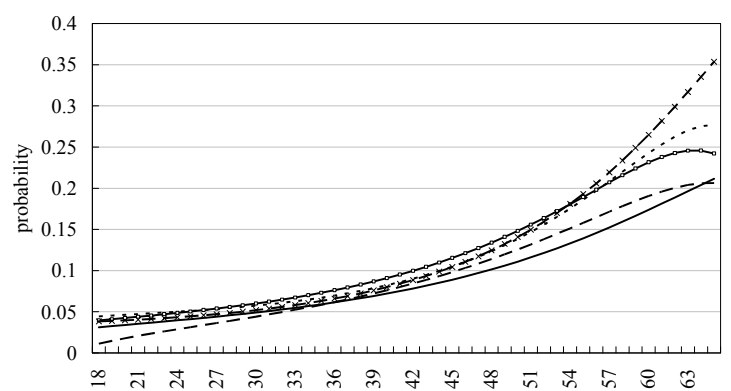

(C) from $-10 \%$ to $+10 \%(k=0)$

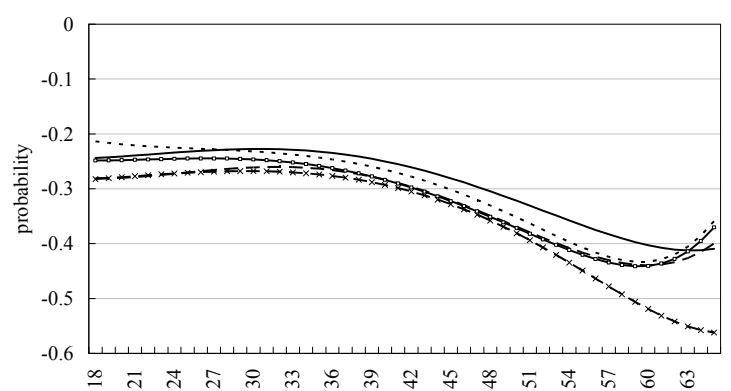

(B) from $-30 \%$ to $-10 \%(k=-15)$

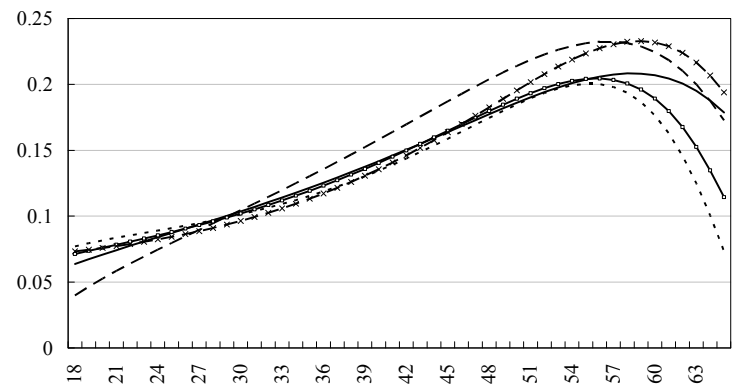

(D) from $+10 \%$ to $+30 \%(k=15)$

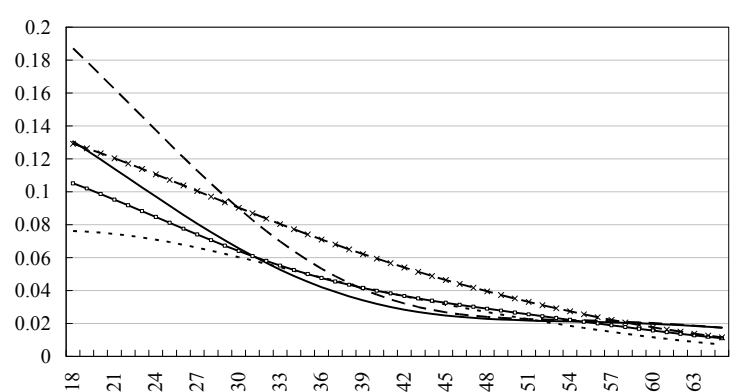

(E) over $+30 \%(k=30)$

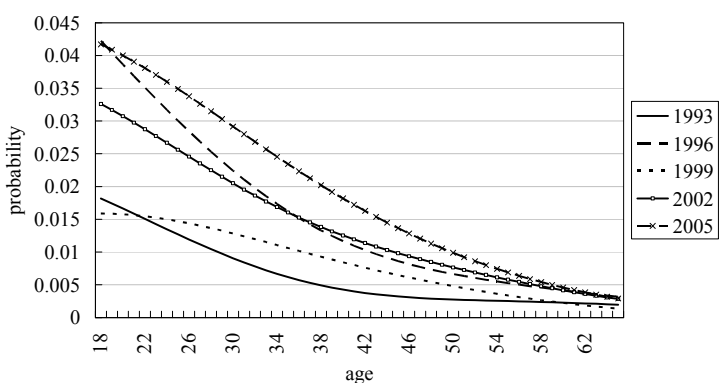

Figure 5a shows the time series effect of age on the job change cost for the involuntarily separated. In terms of the extreme wage loss in panel A, the wage penalty for older workers became more severe after 1996 for older workers. Extreme wage gains for very young workers increased in likelihood in panel E, even as unemployment was rising. Unemployment peaked in 2002, yet probability of a 30\% wage increase in 2002 and in 2005 was higher than in 1999 for 
young involuntary job changers. Below we introduce the same analysis with same set of years but for voluntary job changers.

Figure 5b: Estimated Probability of Wage Change by Age Relatively Evaluated Voluntary Separation 1993, 1996, 1999, 2002, 2005

(A) under $-30 \%(k=-30)$

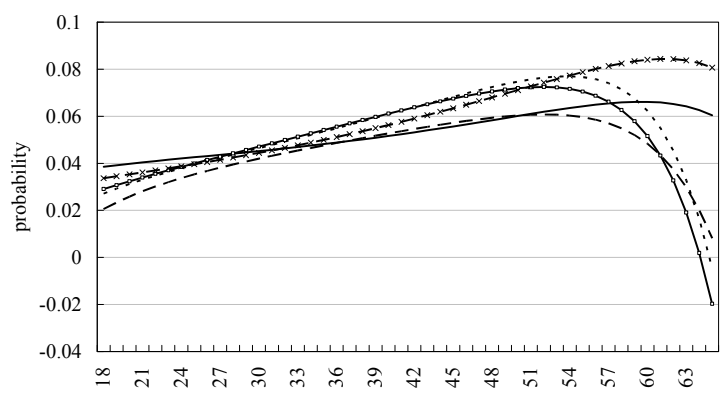

(C) from $-10 \%$ to $+10 \%(k=0)$

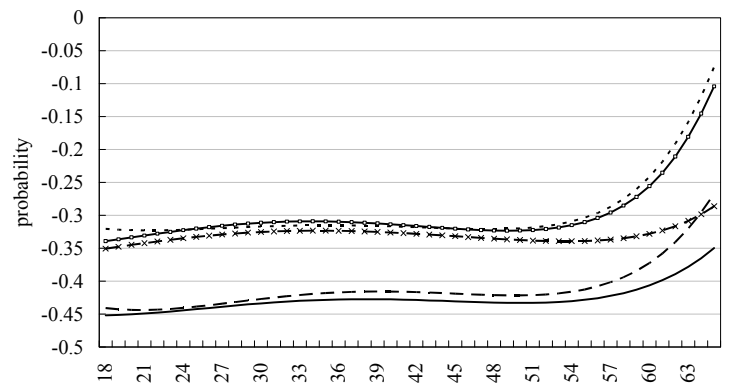

(B) from $-30 \%$ to $-10 \%(k=-15)$

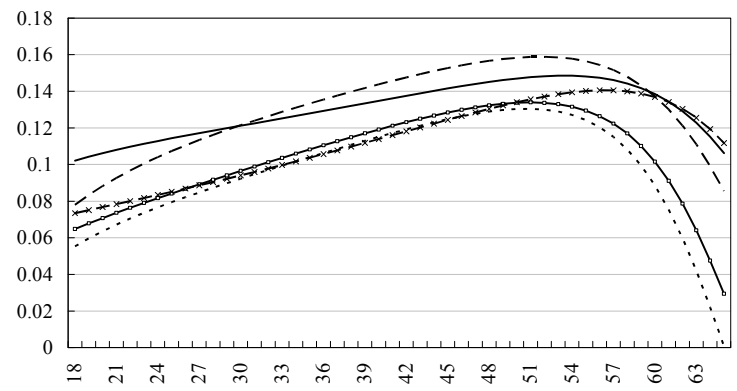

(D) from $+10 \%$ to $+30 \%(k=15)$

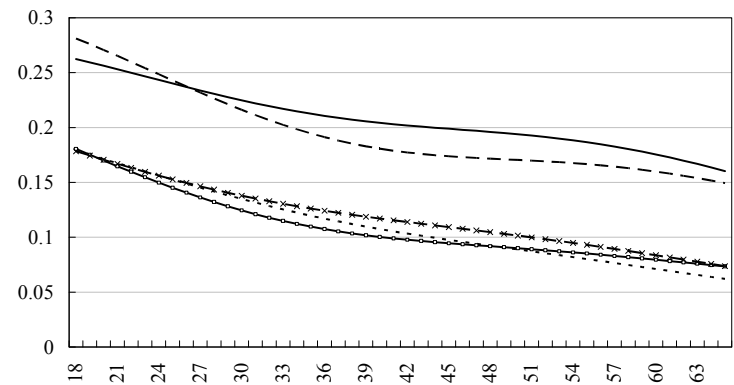

(E) over $+30 \%(k=30)$

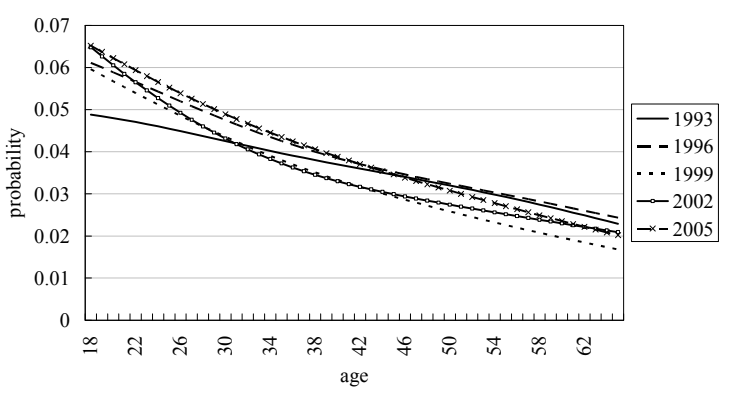


Figure $5 b$ shows the time series effect of age on job change costs for voluntary separations. For those over 50 in panel A, the probability of a large wage was greater in 2005 . The probability of wage gains diminished in all years with age in panels D and $\mathrm{E}$.

\subsection{Industry, Occupation and Career Effects}

When considering whether human capital is industry, occupation or career specific, we code three variables: for workers changing only their industry, changing only their occupation or changing their career. A career change constitutes a change of both industry and occupation. The base category is workers remaining in the same industry and occupation. Table $1 \mathrm{~b}$ is the summary of estimated sign of coefficients.

Table 1b: Summary of Ordered Logit Estimation (Industry, Occupation, and Career Change Effect)

\begin{tabular}{|c|c|c|c|c|c|c|c|c|c|c|c|c|c|c|c|}
\hline & (1) & (2) & (3) & (4) & (5) & (6) & (7) & (8) & (9) & (10) & (11) & $(12)$ & (13) & (14) & (15) \\
\hline Data & 1991 & 1992 & 1993 & 1994 & 1995 & 1996 & 1997 & 1998 & 1999 & 2000 & 2001 & 2002 & 2003 & 2004 & 2005 \\
\hline Industry Change & 0 & $-^{*}$ & $-^{*}$ & $-^{* *}$ & 0 & $--^{* * *}$ & $-^{* * *}$ & 0 & $--^{* * *}$ & $--^{* * *}$ & 0 & 0 & 0 & 0 & 0 \\
\hline Occupation Change & $-{ }^{* * *}$ & $--^{* * *}$ & $-{ }^{* * *}$ & $--^{* * *}$ & $-^{* * *}$ & $--^{* * *}$ & $-^{* * *}$ & $-{ }^{* * *}$ & $-^{* * *}$ & $--^{* * *}$ & $--^{* * *}$ & $--^{* * *}$ & $--^{* * *}$ & $--^{* * *}$ & $-* * *$ \\
\hline Career Change & $-{ }^{* *}$ & $-^{* * *}$ & - - $^{* * *}$ & $-{ }^{* * *}$ & $-^{* * *}$ & $-{ }^{* * *}$ & $-^{* * *}$ & $-{ }^{* * *}$ & $-^{* * *}$ & $-{ }^{* * *}$ & - - $^{* * *}$ & $-^{* * *}$ & $-{ }^{* * *}$ & $-^{* * * *}$ & $-{ }^{* * *}$ \\
\hline Observations & 4463 & 4256 & 4397 & 4010 & 5248 & 4928 & 4806 & 5238 & 5616 & 7002 & 7759 & 9650 & 10064 & 8640 & 8583 \\
\hline
\end{tabular}

\begin{tabular}{|c|c|c|c|c|c|c|c|c|c|c|c|c|c|c|c|}
\hline Data & $\begin{array}{l}(16) \\
1991\end{array}$ & $\begin{array}{l}(17) \\
1992\end{array}$ & $\begin{array}{l}(18) \\
1993\end{array}$ & $\begin{array}{c}(19) \\
1994\end{array}$ & $\begin{array}{c}(20) \\
1995\end{array}$ & $\begin{array}{l}(21) \\
1996\end{array}$ & $\begin{array}{l}(22) \\
1997\end{array}$ & $\begin{array}{c}(23) \\
1998\end{array}$ & $\begin{array}{l}(24) \\
1999\end{array}$ & $\begin{array}{c}(25) \\
2000\end{array}$ & $\begin{array}{l}(26) \\
2001\end{array}$ & $\begin{array}{l}(27) \\
2002\end{array}$ & $\begin{array}{l}(28) \\
2003\end{array}$ & $\begin{array}{c}(29) \\
2004\end{array}$ & $\begin{array}{c}(30) \\
2005\end{array}$ \\
\hline Industry Change & $-^{*}$ & $-^{* * * *}$ & $-^{* * * *}$ & $-^{* * * *}$ & $--^{* * * *}$ & $-^{* * * *}$ & $-^{* * * *}$ & $-^{* * * *}$ & $-^{* * * *}$ & 0 & 0 & 0 & 0 & 0 & 0 \\
\hline Occupation Change & $-^{* * *}$ & - $* * *^{*}$ & $-{ }^{* * *}$ & $-^{* * *}$ & $-^{* * *}$ & $-{ }^{* * *}$ & $-^{* * *}$ & $-^{* * *}$ & $-* * *$ & $-{ }^{* * *}$ & $-^{* * *}$ & $-^{* * *}$ & $-{ }^{* * *}$ & $-^{* * *}$ & $-^{* * *}$ \\
\hline Career Change & $-{ }^{* * *}$ & $-* * *$ & $-{ }^{* * *}$ & $-{ }^{* * *}$ & $-{ }^{* * * *}$ & $-{ }^{* * *}$ & $-^{* * *}$ & $-^{* * *}$ & $-^{* * *}$ & $-{ }^{* * *}$ & $-^{*}$ & $--^{* * *}$ & $-{ }^{* * *}$ & $-^{*}$ & $-^{* * *}$ \\
\hline Observations & 38614 & 31167 & 23763 & 21279 & 23321 & 28218 & 32418 & 26306 & 23151 & 26711 & 25591 & 21960 & 24675 & 25917 & 27556 \\
\hline
\end{tabular}

\begin{tabular}{|c|c|c|c|c|c|c|c|c|c|c|c|c|c|c|c|}
\hline & (31) & (32) & (33) & (34) & (35) & (36) & (37) & (38) & (39) & (40) & (41) & $(42)$ & (43) & (44) & (45) \\
\hline Data & 1991 & 1992 & 1993 & 1994 & 1995 & 1996 & 1997 & 1998 & 1999 & 2000 & 2001 & 2002 & 2003 & 2004 & 2005 \\
\hline Industry Change & 0 & 0 & $-^{* *}$ & 0 & 0 & 0 & $-^{* * *}$ & - ${ }^{* * *}$ & 0 & $+^{* *}$ & $-^{* *}$ & $-^{*}$ & 0 & 0 & 0 \\
\hline Occupation Change & 0 & 0 & 0 & + & 0 & 0 & $-^{*}$ & $-{ }^{* * *}$ & 0 & $t^{* *}$ & $-{ }^{* *}$ & $--^{* * *}$ & $-{ }^{* *}$ & $-^{* *}$ & 0 \\
\hline Career Change & 0 & 0 & $-{ }^{* * *}$ & $-{ }^{* * *}$ & $-^{* * *}$ & $-{ }^{* * *}$ & $-^{* * *}$ & $-{ }^{* * *}$ & $-{ }^{* *}$ & 0 & $-{ }^{* * *}$ & 0 & 0 & $-^{* * *}$ & 0 \\
\hline Observations & 2483 & 3145 & 3304 & 4327 & 4841 & 5020 & 4828 & 4526 & 4141 & 4629 & 5070 & 4446 & 5059 & 4110 & 4547 \\
\hline
\end{tabular}

As a whole, industry, occupation, and career change negatively affect the wage change in separations compared with those who changed jobs without changing industry or occupation. 
Even job changers in the shukko category sometimes had to accept a significant wage reduction. The statistical significance of the industry change dummy vanished after 2000 for both voluntary and involuntary job changers.

As in the discussion of age effects, we can evaluate the magnitude of industry, occupation, and career change by imputing the relative probability in comparison to shukko

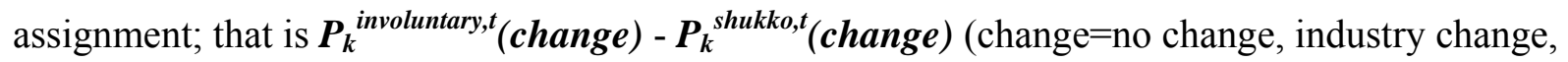
occupation change, and career change; $\mathrm{t}=1991, \ldots, 2005)$. For simplicity, the sample here is limited to involuntary separation and two classes of wage change. Panel (A) aggregates the probabilities and presents wage losses of $10 \%$ or more and panel (B) aggregates the probabilities and presents wage gains of $10 \%$ or more. The 15 year average over the sample period for no change in industry or occupation, industry change, occupation change and career change are in parenthesis in figure 6 .

Figure 6: Estimated Probability of Wage Change by Industry, Occupation, and Career Change Relatively Evaluated Involuntary Separation

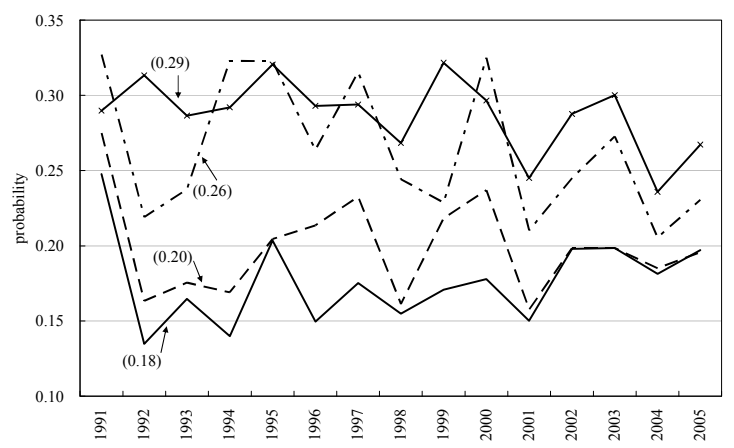

(A) Wage losses of $10 \%$ and more

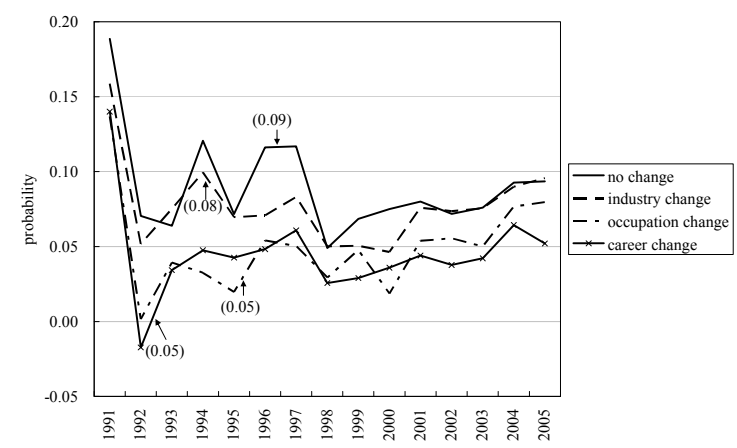

(B) Wage gains of $10 \%$ and more

It is clear that workers remaining in the same industry and occupation fair better than workers changing in one or both dimensions in both panels, for wage losses in panel A and wage gains in panel B. On average over 15 years, involuntary job changers who changed neither industry nor 
occupation experienced a $10 \%$ loss or greater with a probability of 0.18 and a $10 \%$ gain or more with a probability of 0.09 . Penalties from changing industry or occupation still exist after separately accounting for career changes. As for the involuntary job separation with industry change, the results are only slightly worse than for those without any change. Career changers fared the worst over the period. This result is partially in accord with those of Munch (2006) who found support for career specific human capital using Danish data. The penalty for changing careers in our data is more than the penalty for changing only one's industry over the sample period, but it is less than the penalty for changing one's occupation in some years and the two differ only slightly.

While industry change was initially disadvantageous relative to no change, the difference between the profiles disappears entirely in both panels after 2001 . There are two forces potentially related to the relative fall in the cost of industry change. First, wage differentials between industries were declining as displayed in figure 7 that shows the coefficient of variation of 2-digit industry dummies in the standard Mincerian equations from the back ground materials of Kambayashi et al. (2008). This would at least reduce the cost of industry change for those leaving jobs in higher paid industries. It is also possible that industry-specific human capital diminished in importance due to falling training expenditures at the firm level that took place during the 1990 s. $^{9}$

\footnotetext{
${ }^{9}$ Japanese firms reduced training expenditures during the 1990s. The share of training expenditures in total labor cost declined from $0.36 \%$ in 1991 to $0.28 \%$ in 2002 . However, the average share during 1980 s was approximately $0.30 \%$. Therefore, the decline in $1990 \mathrm{~s}$ might be interpreted as a return to previous levels. (Ohki (2003) figure 2, originally from Survey on Working Condition, MHLW.)
} 
Figure 7: Wage Differential due to Industry (1991-2002)

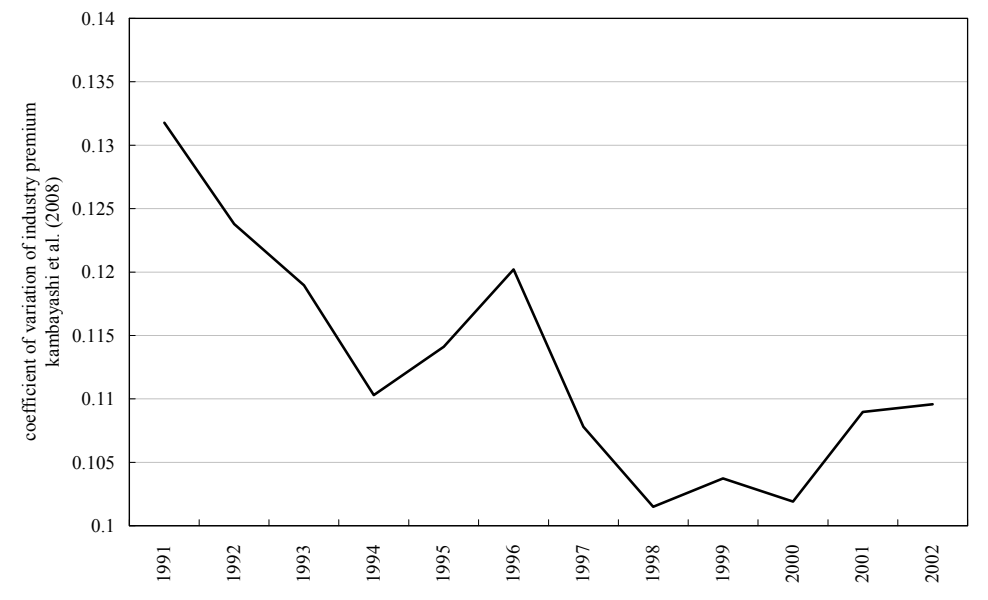

\subsection{Firm Size Effects}

Figure 8 shows the imputed effects of changing firm size. As in figure 6, panel (A) aggregates the probabilities and presents losses $-10 \%$ or more, panel (B) aggregates the probabilities and presents gains of $+10 \%$ or more. The average over the sample period is in parenthesis.

Figure 8: Estimated Probability of Wage Change by Firm Size Change Relatively Evaluated Involuntary Separation

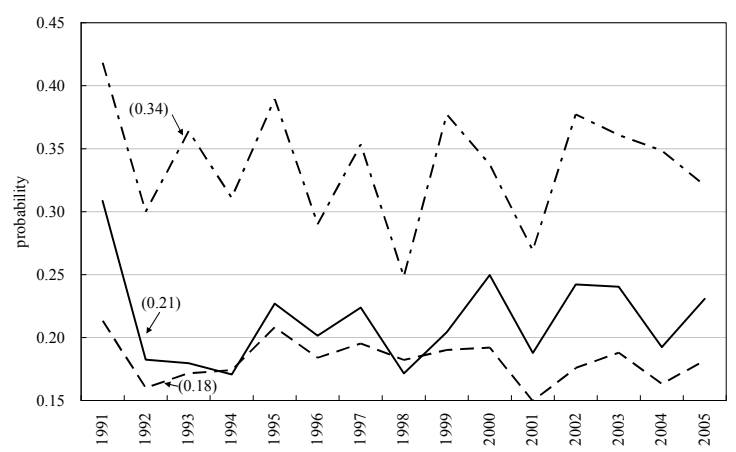

(A) Wage losses of $10 \%$ and more

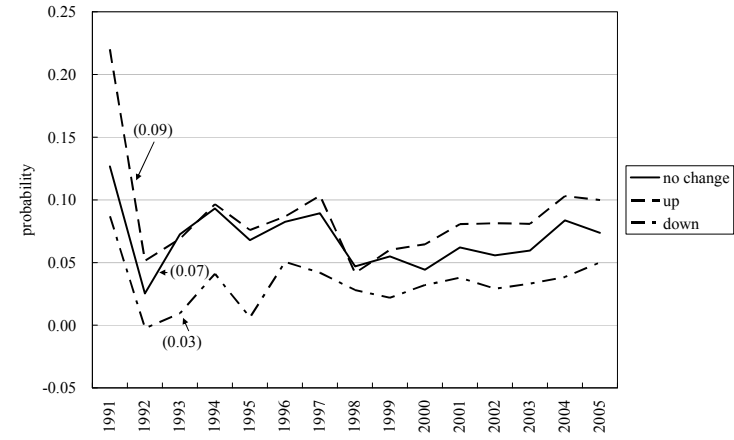

(B) Wage gains of $10 \%$ and more

Panel (A) indicates that the sum of the probabilities of losing $10 \%$ or more in wages is increased by $13 \%$ by moving to a smaller new firm upon reemployment and decreased by $3 \%$ for moving 
to a new larger firm. Correspondingly in panel (B), the probability of gaining $10 \%$ or more in wages is increased $2 \%$ by moving to a larger new firm and diminished by $4 \%$ for moving to a new smaller firm.

\section{Discussion of Trends in Job Change Penalties}

Figure 9 is insightful in depicting the changing consequences of job loss for older workers within our sample period. The figure plots age-wage profiles for newly hired workers and career workers who have all of their labor market experience within the same firm. These profiles are generated from estimations on cross-sectional micro data from 1993 and 2003 for regular workers in the private sector. ${ }^{10}$ The age-wage profiles for career workers are virtually identical in 1993 and 2003 and diverge with age from the profiles of newly hired workers. The disparity in wages between career workers and the newly hired workers grows strongly with age. This is consistent with our estimates pointing to job loss penalties that increase with age.

\footnotetext{
${ }^{10}$ Kambayashi et al. (2008a) report these estimations from their analysis of the Basic Survey of Wage Structure. The estimations are from its back ground materials and included controls for gender, educational level, age, age ${ }^{2}$, firm size, industry and prefecture. The effect of age on wages is calculated and then standardized so that an 18-year-old worker has wages equal to one in each of the profiles. Career workers are those with firm tenure equal to their age minus the years required to attain their educational level.
} 
Figure 9: Age-Wage Profile for New Hires and Career Workers without a Job Change

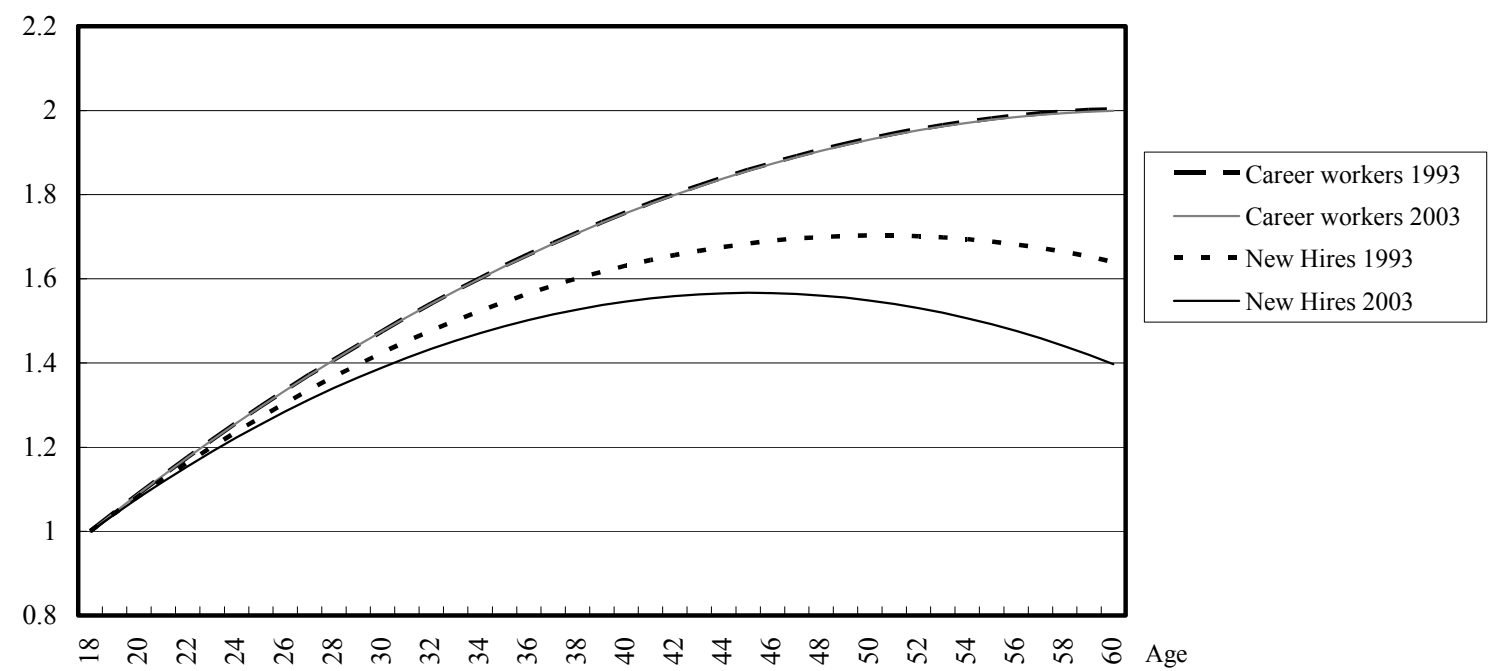

Notes: The estimation of $\ln ($ hourly wage $)=$ const. + female dummy + educational dummies + age + age $2+$ Firm size dummies + Indusry dummies + Prefecture dummies was performed in 1993 and 2003.

Source: The back ground material of Kambayashi et al. (2008a) analysis of the Basic Survey of Wage Structure restricted to private sector, regular workers. The effect of age on wages is calculated and then standardized so that an 18 year old worker has wages equal to one in each of the profiles. Career workers are those with firm tenure equal to their age minus the years required to attain their educational level.

While the profiles for career workers in 1993 and 2003 are similar, the slope of the wage profile for newly hired workers in 2003 fell significantly from the wage profile in 1993. As a result, the penalty for older job changers was increasing. This is also consistent with our finding in figure 5 of an increasingly negative outcome for older workers during the sample period.

To examine potential reasons behind the increase in the cost of job change, we first consider the trends in basic labor market conditions. In the period from 1974 to 2005, the gross turnover rate fluctuated between 25 and $35 \%$ with no trend during the period. ${ }^{11}$ Similarly, the

\footnotetext{
${ }^{11}$ The gross turnover rate is the number of workers leaving employment and the number of workers entering employment divided by the total number of workers in the beginning of the year. Figure 2 in the working paper displays the gross turnover rate and inflow rate of job changers over time.
} 
inflow rate of job changers in the labor market fluctuates between 5 and $10 \%$ with no trend. ${ }^{12}$ The increasing trend in overall job change penalties cannot be related to turnover rates in any readily apparent way.

Another avenue for investigation concerns the potential loss of specific capital. Did a larger percentage of workers lose specific capital during the sample period due to industry change? In fact over the sample period there was very little change in the percentage of workers finding reemployment in the same industry and occupation. The percentage of workers changing industry fell by $0.3 \%$ between 1991 and 2005 . In the same period, occupation changes increased $1.1 \%$. These small changes were offset by a fall in career changes of $4.5 \%$. The net effect is that $3.8 \%$ more workers undergoing job change remained in the same industry and occupation. There is no support for the argument that an increase in the percentage of job changers losing specific capital explains the increase in job change penalties.

If about same percentage of workers remained in their industry and occupation through job change, was it the case that the penalties associated with industry change grew? Figure 7 displays two points. First, industry change penalties actually fell during the sample period. Second, wage differentials between industries were falling. Hence, increasing job change penalties do not appear to be driven by increasing penalties for changing industry. This point was also evident in figure 6 that showed that the costs of changing industry and occupation diminished, as did the cost of going to a smaller firm upon reemployment.

The only labor market condition that we can point to in suggesting a reason for the increasing job change penalties is the rising unemployment rate and the increase in the percentage of involuntary job changes displayed in figure 1.

\footnotetext{
${ }^{12}$ The inflow rate of job changers is the number of workers entering employment from previous employment with unemployment duration of less than a year divided by the number of workers at the beginning of the year.
} 
As for the older workers, we can only speculate as to why older job changers were treated increasingly less favorably in the labor market. It may be that prior to Japan's long recession, firms could afford to honor the delayed payment contracts entered into by older workers at their prior firms. A second potential explanation is that technological change induced a loss of human capital for older workers relative to younger workers between 1993 and 2003. The effects of a loss in human capital for older workers would be felt by those changing jobs. Implicit contracts would protect workers remaining in continuous employment. This explanation is consistent with wage profiles remaining the same for career workers but falling in slope for the newly hired workers in 2003. However, if the technological change was global, we are at a loss to explain why job change penalties were not also increasing and related in ages in the US. To illustrate this point, we provide a comparison between Japan and U.S. in the next section.

\section{A Japan/U.S. Comparison}

Interestingly, a comparison of the US and Japan in table 2 shows that the countries do not share the same trends in job loss penalties. We report Farber's (2003) results using the Displaced Worker Survey and tailor our sample and estimation to match his as closely as possible. ${ }^{13}$ The base category for the US is white males from 20-24 with 12 years of education and less than one year of tenure. Given the base category, insignificant results for the age group dummy variable of those 25-34 is not surprising. Those aged 35-44 in the US sample ending in 1993 lose $13 \%$ in earnings relative to the base category. In the later sample years for the US, this age category has results that are statistically insignificant, though the coefficients become positive and close to significant in 2001. Similarly, for US workers aged 45-54, job change penalties are significantly

\footnotetext{
${ }^{13}$ Both samples are restricted to those between 20 and 64 and undergoing full-time to full-time job transitions. Rather than ordered logit, our estimates in table 1 are OLS to facilitate a comparison to Farber's estimates.
} 
greater in the 1993 and 1995 samples but lose significance thereafter. For US workers aged 5564, significantly negative effects are only evidenced in 1993 and 1995. They become insignificant and positive by 2001. There is no evidence of increasingly age-related job change penalties in the US, rather age-related penalties appear to decrease.

Table 2: US/Japan Comparison

\begin{tabular}{|c|c|c|c|c|c|c|c|c|c|c|}
\hline Estimation method & \multicolumn{10}{|c|}{ OLS } \\
\hline Dependent variable & \multicolumn{5}{|c|}{$\begin{array}{l}\text { Post-displacement log weekly earnings minus pre-displacement log } \\
\text { weekly earnings }\end{array}$} & \multicolumn{5}{|c|}{ Wage $\begin{aligned} \Delta & =-30 \%(\Delta<-30 \%),-15 \%(-30 \%<\Delta<-10 \%), 0(-10 \%<\Delta \\
& <+10 \%), 15 \%(10 \%<\Delta<30 \%), 30 \%(\Delta>30 \%)\end{aligned}$} \\
\hline Data & \multicolumn{5}{|c|}{ Farber's U.S. estimates from DWS (weighted by CPS sampling weights) } & \multicolumn{5}{|c|}{ Japan: Employment Trend Survey Microdata, Involuntary Separtion } \\
\hline Base category & \multicolumn{5}{|c|}{ White males, $20-24,12$ yrs education, less than 1 yr tenure } & \multicolumn{5}{|c|}{ Males, $20-24,12$ yrs education } \\
\hline Period & $\begin{array}{c}(1) \\
1991-93\end{array}$ & $\begin{array}{c}(2) \\
1993-95\end{array}$ & $\begin{array}{c}(3) \\
1995-97\end{array}$ & $\begin{array}{c}(4) \\
1997-99\end{array}$ & $\begin{array}{c}(5) \\
1999-01\end{array}$ & $\begin{array}{c}(6) \\
1992-93\end{array}$ & $\begin{array}{c}(7) \\
1994-95\end{array}$ & $\begin{array}{c}(8) \\
1996-97\end{array}$ & $\begin{array}{c}(9) \\
1998-99\end{array}$ & $\begin{array}{c}(10) \\
2000-01\end{array}$ \\
\hline Constant & $\begin{array}{c}0.035 \\
(0.050) \\
\end{array}$ & $\begin{array}{c}0.053 \\
(0.042) \\
\end{array}$ & $\begin{array}{c}0.028 \\
(0.062) \\
\end{array}$ & $\begin{array}{c}0.065 \\
(0.058) \\
\end{array}$ & $\begin{array}{c}0.075 \\
(0.051) \\
\end{array}$ & $\begin{array}{c}0.001 \\
(0.005)\end{array}$ & $\begin{array}{c}-0.014 \\
(0.006)^{* *}\end{array}$ & $\begin{array}{l}-0.001 \\
(0.006) \\
\end{array}$ & $\begin{array}{c}-0.027 \\
(0.005)^{* * *}\end{array}$ & $\begin{array}{l}-0.006 \\
(0.005)\end{array}$ \\
\hline Female & $\begin{array}{c}0.030 \\
(0.025)\end{array}$ & $\begin{array}{c}0.015 \\
(0.024)\end{array}$ & $\begin{array}{c}0.052 \\
(0.033)\end{array}$ & $\begin{array}{l}-0.019 \\
(0.031)\end{array}$ & $\begin{array}{c}0.011 \\
(0.029) \\
\end{array}$ & $\begin{array}{c}0.034 \\
(0.003)^{* * *}\end{array}$ & $\begin{array}{c}0.040 \\
(0.003)^{* * *}\end{array}$ & $\begin{array}{c}0.029 \\
(0.004)^{* * *}\end{array}$ & $\begin{array}{c}0.037 \\
(0.003)^{* * *}\end{array}$ & $\begin{array}{c}0.024 \\
(0.003)^{* * *}\end{array}$ \\
\hline Education $<12$ & $\begin{array}{c}0.084 \\
(0.043)\end{array}$ & $\begin{array}{c}0.028 \\
(0.042)\end{array}$ & $\begin{array}{l}-0.041 \\
(0.056)\end{array}$ & $\begin{array}{c}0.038 \\
(0.060)\end{array}$ & $\begin{array}{c}0.000 \\
(0.058)\end{array}$ & $\begin{array}{c}0.037 \\
(0.003)^{* * *}\end{array}$ & $\begin{array}{c}0.042 \\
(0.004)^{* * *}\end{array}$ & $\begin{array}{c}0.050 \\
(0.004) * * *\end{array}$ & $\begin{array}{c}0.045 \\
(0.004)^{* * *}\end{array}$ & $\begin{array}{c}0.025 \\
(0.004)^{* * *}\end{array}$ \\
\hline Education 13-15 & $\begin{array}{c}0.029 \\
(0.028)\end{array}$ & $\begin{array}{l}-0.006 \\
(0.028)\end{array}$ & $\begin{array}{l}-0.011 \\
(0.040)\end{array}$ & $\begin{array}{l}-0.013 \\
(0.037)\end{array}$ & $\begin{array}{l}-0.003 \\
(0.035)\end{array}$ & $\begin{array}{c}-0.025 \\
(0.007)^{* * *}\end{array}$ & $\begin{array}{c}-0.020 \\
(0.007)^{* * *}\end{array}$ & $\begin{array}{c}-0.010 \\
(0.005)^{*}\end{array}$ & $\begin{array}{l}-0.006 \\
(0.005)\end{array}$ & $\begin{array}{c}-0.009 \\
(0.004)^{* *}\end{array}$ \\
\hline Education $>15$ & $\begin{array}{c}0.067 \\
(0.032)^{*}\end{array}$ & $\begin{array}{l}-0.022 \\
(0.030)\end{array}$ & $\begin{array}{c}0.052 \\
(0.042)\end{array}$ & $\begin{array}{l}-0.018 \\
(0.040)\end{array}$ & $\begin{array}{c}0.019 \\
(0.038)\end{array}$ & $\begin{array}{c}-0.018 \\
(0.005)^{* * *}\end{array}$ & $\begin{array}{c}-0.011 \\
(0.005)^{* *}\end{array}$ & $\begin{array}{c}-0.013 \\
(0.004) * * *\end{array}$ & $\begin{array}{l}-0.003 \\
(0.004)\end{array}$ & $\begin{array}{c}-0.007 \\
(0.004)^{*}\end{array}$ \\
\hline Age $25-34$ & $\begin{array}{l}-0.019 \\
(0.043) \\
\end{array}$ & $\begin{array}{c}0.008 \\
(0.043) \\
\end{array}$ & $\begin{array}{c}0.016 \\
(0.060) \\
\end{array}$ & $\begin{array}{c}0.002 \\
(0.058) \\
\end{array}$ & $\begin{array}{l}-0.095 \\
(0.051) \\
\end{array}$ & $\begin{array}{l}-0.010 \\
(0.006) \\
\end{array}$ & $\begin{array}{l}-0.002 \\
(0.007) \\
\end{array}$ & $\begin{array}{l}-0.007 \\
(0.006) \\
\end{array}$ & $\begin{array}{l}-0.003 \\
(0.006) \\
\end{array}$ & $\begin{array}{l}-0.006 \\
(0.005) \\
\end{array}$ \\
\hline Age $35-44$ & $\begin{array}{c}-0.128 \\
(0.044)^{* *}\end{array}$ & $\begin{array}{l}-0.080 \\
(0.045)\end{array}$ & $\begin{array}{l}-0.051 \\
(0.061)\end{array}$ & $\begin{array}{c}0.018 \\
(0.059) \\
\end{array}$ & $\begin{array}{c}0.081 \\
(0.053)\end{array}$ & $\begin{array}{c}-0.023 \\
(0.006)^{* * *}\end{array}$ & $\begin{array}{l}-0.011 \\
(0.007)\end{array}$ & $\begin{array}{c}-0.021 \\
(0.007)^{* * *}\end{array}$ & $\begin{array}{c}-0.021 \\
(0.006)^{* * *}\end{array}$ & $\begin{array}{c}-0.025 \\
(0.006)^{* * *}\end{array}$ \\
\hline Age 45-54 & $\begin{array}{c}-0.139 \\
(0.049)^{* *}\end{array}$ & $\begin{array}{c}-0.095 \\
(0.048)^{*}\end{array}$ & $\begin{array}{l}-0.044 \\
(0.065)\end{array}$ & $\begin{array}{l}-0.046 \\
(0.063)\end{array}$ & $\begin{array}{l}-0.101 \\
(0.056)\end{array}$ & $\begin{array}{c}-0.054 \\
(0.006)^{* * *}\end{array}$ & $\begin{array}{c}-0.055 \\
(0.007)^{* * *}\end{array}$ & $\begin{array}{c}-0.070 \\
(0.006) * * *\end{array}$ & $\begin{array}{c}-0.054 \\
(0.006)^{* * *}\end{array}$ & $\begin{array}{c}-0.074 \\
(0.005)^{* * *}\end{array}$ \\
\hline Age $55-64$ & $\begin{array}{c}-0.222 \\
(0.060)^{* *} \\
\end{array}$ & $\begin{array}{c}-0.150 \\
(0.063)^{*} \\
\end{array}$ & $\begin{array}{c}-0.123 \\
(0.083) \\
\end{array}$ & $\begin{array}{c}0.021 \\
(0.077) \\
\end{array}$ & $\begin{array}{c}0.035 \\
(0.072) \\
\end{array}$ & $\begin{array}{c}-0.121 \\
(0.006)^{* * *}\end{array}$ & $\begin{array}{c}-0.116 \\
(0.007)^{* * *} \\
\end{array}$ & $\begin{array}{c}-0.152 \\
(0.006)^{* * *}\end{array}$ & $\begin{array}{c}-0.133 \\
(0.006)^{* * *}\end{array}$ & $\begin{array}{c}-0.155 \\
(0.005)^{* * *} \\
\end{array}$ \\
\hline $\begin{array}{c}\mathrm{N} \\
\text { R-squared }\end{array}$ & $\begin{array}{l}2032 \\
0.057\end{array}$ & $\begin{array}{c}1663 \\
0.052\end{array}$ & $\begin{array}{c}1558 \\
0.027\end{array}$ & $\begin{array}{l}1492 \\
0.015\end{array}$ & $\begin{array}{l}1804 \\
0.032\end{array}$ & $\begin{array}{l}6972 \\
0.160\end{array}$ & $\begin{array}{l}7049 \\
0.155\end{array}$ & $\begin{array}{l}7163 \\
0.217\end{array}$ & $\begin{array}{l}7858 \\
0.201\end{array}$ & $\begin{array}{l}9510 \\
0.221\end{array}$ \\
\hline
\end{tabular}
Note: U.S. estimates come from Farber (2003). Farber also controlled for nonwhite, for tenure of 1-3, 4-10, 11-20, over 20,2 yrs since job loss, 3 years since job loss but, since we lack these variables, we do not report them for the US.

Both samples are restricted to those between 20 and 64 and undergoing full-time to full-time job transitions.

The base category for Japan is males from 20-24 with 12 years of education. Just as with the US, the dummy variable estimates for Japanese males 25-34 are insignificant. For all of the older age categories in Japan, workers have larger wage losses than those 20-24. Moreover, an increasing trend in the job loss penalty for the oldest workers is evident. The job change penalty grows from $12.2 \%$ for workers $55-64$ in 1993 relative to the base category to $15.5 \%$ by 2001. This contrasts with the US where workers 55-64 lost an additional $22.2 \%$ in earnings in 
1993 relative to the base category but had no significant difference beginning in 1997 and continuing to 2001 .

If technological change reduced the productivity of older workers in Japan during the sample period, causing increasingly large job change costs, this was not evident in the U.S. The technological change argument is not supported in this comparison.

\section{Conclusion}

Few studies of job change in the Japanese labor market appear in the literature. This is largely due to the difficulty of obtaining worker level data. We study a large national sample of workers to document basic trends regarding the wage implications of job change. In doing so, both anticipated and novel results were found.

Because of a worsening in the labor market conditions during the period studied, at least in terms of the unemployment rate, it is not surprising that workers changing jobs had increasingly less favorable outcomes between 1991 and 2005. Given the strong returns to seniority in Japan, it was also not surprising that older workers had larger job change penalties than younger workers.

The extent to which older workers suffered reduced wages from job change grew during the sample period, a finding not seen in U.S. data. Correspondingly, there was a reduction in the return to age for those finding new employment in the Japanese labor market. We offered two hypotheses for these findings. First, the reluctance of firms to honor the delayed payment contracts that workers had entered into with their previous employers may have been increasing. Second, technological change may have eroded the human capital of older workers. The effects of this would be felt by the older workers needing to find new employment since continuously 
employed workers are shielded by the implicit contracts operating within the firm. Both of these hypotheses merit further investigation as we can say nothing conclusively about why older workers are receiving a lower return on their experience. 


\section{References}

Abe, Masahiro, Yoshio Higuchi, Masao Nakamura, Peter Kuhn and Arthur Sweetman. 2002. "Worker Displacement in Japan and Canada." In Peter Kuhn, ed., Losing Work, Moving On: International Perspectives on Worker Displacement. Upjohn Institute for Employment Research, Chapter 3.

Blau, Francine, and Lawrence Kahn. 2000. "Gender Differences in Pay." The Journal of Economic Perspectives, Vol. 14, No. 4. (Autumn), pp. 75-99.

Bognanno, Michael, and Lisa Delgado. 2008. "Earnings Losses Following Job Change in Japan: Evidence from a Job Placement Firm.” Research in Labor Economics, Vol. 28, pp. 225-250.

Clark, Robert, and Naohiro Ogawa. 1992. "The Effect of Mandatory Retirement on Earnings Profiles in Japan." Industrial and Labor Relations Review, Vol.45, No.2, pp. 258-66.

Fallick, Bruce. 1996. "A Review of the Recent Empirical Literature on Displaced Workers." Industrial and Labor Relations Review, Vol. 50, No.1, pp. 5-16.

Henry Farber. 1997. "The Changing Face of Job Loss in the United States, 1981-1995." Brookings Papers on Economic Activity. Microeconomics, pp. 55-142.

Henry Farber. 2003. "Job Loss in the United States, 1981-2001." Princeton University, Industrial Relations Section, Working Paper \#471.

Daniel Hamermesh. 1989. "What Do We Know About Worker Displacement in the United States?" Industrial Relations, Vol. 28, No.1 (Winter), pp. 51-59.

Masanori Hashimoto, and John Raisian. 1985. "Employment Tenure and Earnings Profiles in Japan and the United States." American Economic Review, Vol. 75, No.4, pp. 721-735.

Japan Institute of Labor, Policy and Training. 2005. "Labor Situation in Japan and Analysis, 2004/2005." http://www.jil.go.jp/english/laborinfo/library/situation2004.htm.

Kambayashi, Ryo; Daiji Kawaguchi, and Izumi Yokoyama. 2008a. "Wage Distribution in Japan: 1989-2003.” Canadian Journal of Economics, Vol.41, No.4, pp.1329-1350.

Kambayashi, Ryo. (ed.) 2008b. Kaiko-kisei no Hoh to Keizai (Law and Economics in Dismissal Regulation) Nihon-Hyoron-Sha.

Kato, Takao. 2001. "The End of Lifetime Employment in Japan?: Evidence from National Surveys and Field Research." Journal of the Japanese and International Economies, Vol.15, No. 4, pp. 489-514.

Kletzer, Lori. 1998. "Job Displacement.” The Journal of Economics Perspectives, Vol. 12, No. 1 (Winter), 115-136. 
Koike, Kazuo. 1988. Understanding Industrial Relations in Modern Japan. Translated by Mary Saso. New York: St. Martin's Press.

Jacobson, Louis S., Robert J. LaLonde and Daniel G. Sullivan. 1993. "Earnings Losses of Displaced Workers.” The American Economic Review, Vol. 83, No. 4, pp. 685-709.

Munch, Jakob Roland. 2006. "Career Changes and the Loss of Human Capital." Unpublished paper, University of Copenhagen.

Rebick, Marcus. 2005. The Japanese Employment System: Adapting to a New Economic Environment. Oxford: Oxford University Press.

Ruhm, Christopher J. 1991. “Are Workers Permanently Scarred by Job Displacements?” The American Economic Review, Vol. 81, No. 1, pp. 319-324.

Statistics and Information Department. 2003. Ministry of Health, Labour and Welfare. "2003 Survey of Employment Management - Retirement Management," Table 7.

Tachibanaki, Toshiaki. 1998. 'Introduction to Wage Differentials: An International Comparison.' In Toshiaki Tachibanaki, ed., Wage Differentials: An International Comparison. New York: St. Martin's Press.

Topel, Robert. 1993. "What Have We Learned from Empirical Studies of Unemployment and Turnover?" American Economic Review, Vol. 83, No. 2, Papers and Proceedings of the Hundred and Fifth Annual Meeting of the American Economic Association, pp. 110-11. 


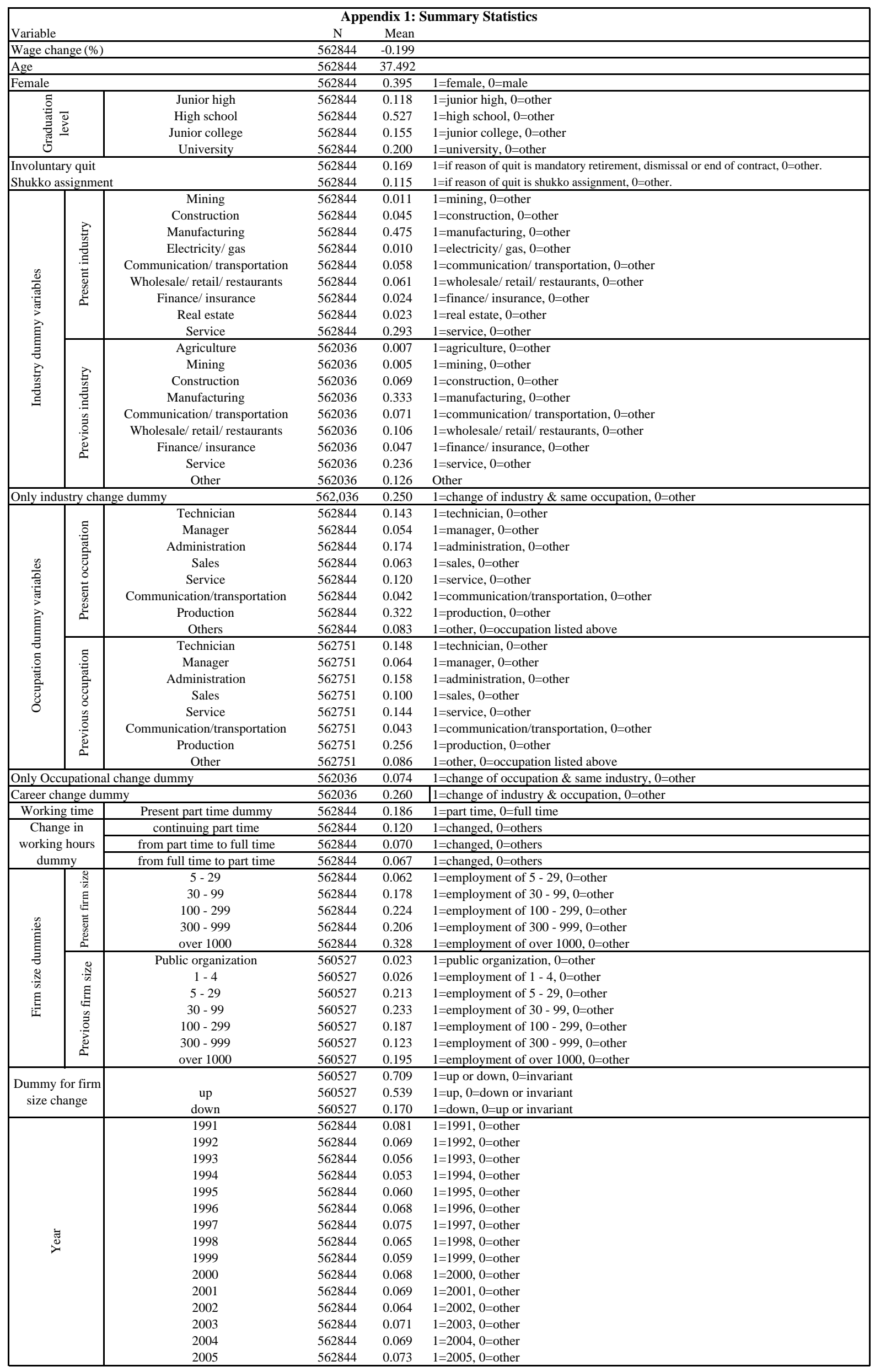


Appendix 2a: Results of Ordered Logit (Involuntary Separation Sample)

\begin{tabular}{|c|c|c|c|c|c|c|c|c|c|c|c|c|c|c|c|c|c|}
\hline \multirow{2}{*}{\multicolumn{3}{|c|}{ Dependent variable }} & (1) & (2) & (3) & (4) & (5) & (6) & (7) & (8) & (9) & (10) & (11) & (12) & (13) & (14) & (15) \\
\hline & & & \multicolumn{15}{|c|}{ Wage variation (five categories: $-30,-15,0 \%, 1:+10,+30$ ) } \\
\hline \multirow{2}{*}{\multicolumn{3}{|c|}{ Data }} & 1991 & 1992 & 1993 & 1994 & 1995 & 1996 & 1997 & 1998 & 1999 & 2000 & 2001 & 2002 & 2003 & 2004 & 2005 \\
\hline & & & \multicolumn{15}{|c|}{ Involuntary Separations } \\
\hline \multicolumn{3}{|c|}{ Estimation method } & \multicolumn{15}{|c|}{ Ordered Logit } \\
\hline \multicolumn{3}{|r|}{ Age } & $\begin{array}{c}-0.014 \\
(0.017)\end{array}$ & $\begin{array}{r}0.002 \\
(0.019)\end{array}$ & $\begin{array}{c}-0.002 \\
(0.018)\end{array}$ & $\begin{array}{l}0.039 \\
(0.018)^{* * *}\end{array}$ & $\begin{array}{r}0.023 \\
(0.016)\end{array}$ & $\begin{array}{r}-0.026 \\
(0.016)\end{array}$ & $\begin{array}{r}0.023 \\
(0.016)\end{array}$ & $\begin{array}{c}0.016 \\
(0.018)\end{array}$ & $\begin{array}{l}0.050 \\
(0.017)^{* * * *}\end{array}$ & $\begin{array}{c}0.027 \\
(0.014)^{*}\end{array}$ & $\begin{array}{l}0.041 \\
(0.014)^{* * * *}\end{array}$ & $\begin{array}{r}0.007 \\
(0.012)\end{array}$ & $\begin{array}{r}0.008 \\
(0.012)\end{array}$ & $\begin{array}{r}-0.001 \\
(0.013)\end{array}$ & $\begin{array}{c}0.021 \\
(0.013)^{*}\end{array}$ \\
\hline \multicolumn{3}{|r|}{$\mathrm{Age}^{2}$} & $\begin{array}{r}0.004 \\
(0.023)\end{array}$ & $\begin{array}{l}-0.050 \\
(0.021)^{* * *}\end{array}$ & $\begin{array}{l}-0.051 \\
(0.020)^{* * *}\end{array}$ & $\begin{array}{l}-0.097 \\
(0.021)^{* * * *}\end{array}$ & $\begin{array}{c}-0.078 \\
(0.018)^{* * * *}\end{array}$ & $\begin{array}{c}-0.034 \\
(0.018)^{*}\end{array}$ & $\begin{array}{c}-0.088 \\
(0.019)^{* * * *}\end{array}$ & $\begin{array}{c}-0.084 \\
(0.020)^{* * * *}\end{array}$ & $\begin{array}{c}-0.123 \\
(0.019)^{* * * *}\end{array}$ & $\begin{array}{c}-0.098 \\
(0.016)^{* * * *}\end{array}$ & $\begin{array}{c}-0.114 \\
(0.016)^{* * * *}\end{array}$ & $\begin{array}{c}-0.073 \\
(0.014)^{* * * *}\end{array}$ & $\begin{array}{c}-0.078 \\
(0.013)^{* * * *}\end{array}$ & $\begin{array}{l}-0.075 \\
(0.015)^{* * * *}\end{array}$ & $\begin{array}{c}-0.095 \\
(0.014)^{* * * *}\end{array}$ \\
\hline \multirow{3}{*}{ 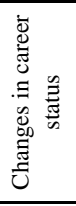 } & \multirow{3}{*}{ 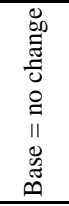 } & Industry Change & $\begin{array}{c}-0.116 \\
(0.077)\end{array}$ & $\begin{array}{c}-0.214 \\
(0.102)^{* *}\end{array}$ & $\begin{array}{c}-0.165 \\
(0.094)^{*}\end{array}$ & $\begin{array}{c}-0.199 \\
(0.098)^{* * *}\end{array}$ & $\begin{array}{r}.000 \\
(0.085)\end{array}$ & $\begin{array}{c}-0.386 \\
(0.080)^{* * * *}\end{array}$ & $\begin{array}{c}-0.363 \\
(0.080)^{* * * *}\end{array}$ & $\begin{array}{r}-0.103 \\
(0.085)\end{array}$ & $\begin{array}{c}-0.293 \\
(0.080)^{* * *}\end{array}$ & $\begin{array}{c}-0.321 \\
(0.071)^{* * * *}\end{array}$ & $\begin{array}{r}-0.096 \\
(0.070)\end{array}$ & $\begin{array}{r}-0.035 \\
(0.059)\end{array}$ & $\begin{array}{r}-0.024 \\
(0.057)\end{array}$ & $\begin{array}{r}-0.045 \\
(0.060)\end{array}$ & $\begin{array}{c}0.001 \\
(0.059)\end{array}$ \\
\hline & & Occupation Change & $\begin{array}{l}-0.424 \\
(0.117)^{* * * *}\end{array}$ & $\begin{array}{l}-0.507 \\
(0.156)^{* * * *}\end{array}$ & $\begin{array}{l}-0.476 \\
(0.14)^{* * * *}\end{array}$ & $\begin{array}{l}-0.820 \\
(0.143)^{* * * *}\end{array}$ & $\begin{array}{c}-0.588 \\
(0.121)^{* * * *}\end{array}$ & $\begin{array}{c}-0.690 \\
(0.124)^{* * * *}\end{array}$ & $\begin{array}{c}-0.769 \\
(0.130)^{* * * *}\end{array}$ & $\begin{array}{c}-0.699 \\
(0.128)^{* * * *}\end{array}$ & $\begin{array}{c}-0.393 \\
(0.115)^{* * * *}\end{array}$ & $\begin{array}{c}-0.740 \\
(0.106)^{* * * *}\end{array}$ & $\begin{array}{l}-0.458 \\
(0.099)^{*+* * *}\end{array}$ & $\begin{array}{c}-0.403 \\
(0.083)^{* * * *}\end{array}$ & $\begin{array}{l}-0.461 \\
(0.083)^{* * * *}\end{array}$ & $\begin{array}{l}-0.241 \\
(0.086)^{* * * *}\end{array}$ & $\begin{array}{l}-0.222 \\
(0.084)^{* * * * *}\end{array}$ \\
\hline & & Career Change & $\begin{array}{c}-0.173 \\
(0.073)^{* * *}\end{array}$ & $\begin{array}{l}-0.990 \\
(0.106)^{* * * *}\end{array}$ & $\begin{array}{l}-0.790 \\
(0.101)^{* * * *}\end{array}$ & $\begin{array}{l}-0.937 \\
(0.100)^{* * * *}\end{array}$ & $\begin{array}{c}-0.723 \\
(0.088)^{* * * *}\end{array}$ & $\begin{array}{c}-0.886 \\
(0.084)^{* * * *}\end{array}$ & $\begin{array}{c}-0.723 \\
(0.086)^{* * * *}\end{array}$ & $\begin{array}{c}-0.809 \\
(0.089)^{* * * *}\end{array}$ & $\begin{array}{c}-0.841 \\
(0.084)^{* * * *}\end{array}$ & $\begin{array}{c}-0.645 \\
(0.073)^{* * * *}\end{array}$ & $\begin{array}{c}-0.668 \\
(0.071)^{* * * *}\end{array}$ & $\begin{array}{c}-0.461 \\
(0.060)^{* * * *}\end{array}$ & $\begin{array}{c}-0.496 \\
(0.059)^{* * * *}\end{array}$ & $\begin{array}{c}-0.427 \\
(0.063)^{* * * *}\end{array}$ & $\begin{array}{c}-0.363 \\
(0.065)^{* * * *}\end{array}$ \\
\hline \multirow{2}{*}{ 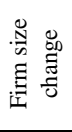 } & \multirow{2}{*}{ 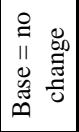 } & Larger Firm & $\begin{array}{l}0.458 \\
(0.069)^{* * * *}\end{array}$ & $\begin{array}{r}0.118 \\
(0.080)\end{array}$ & $\begin{aligned} 0.107 \\
(0.082)\end{aligned}$ & $\begin{array}{r}0.088 \\
(0.078)\end{array}$ & $\begin{array}{c}0.115 \\
(0.069)^{*}\end{array}$ & $\begin{array}{l}0.166 \\
(0.070)^{* * *}\end{array}$ & $\begin{array}{l}0.205 \\
(0.070)^{* * * *}\end{array}$ & $\begin{array}{r}-0.002 \\
(0.074)\end{array}$ & $\begin{array}{c}0.121 \\
(0.069)^{*}\end{array}$ & $\begin{array}{l}0.330 \\
(0.061)^{* * * *}\end{array}$ & $\begin{array}{l}0.276 \\
(0.059)^{* * * *}\end{array}$ & $\begin{array}{l}0.421 \\
(0.051)^{* * * *}\end{array}$ & $\begin{array}{l}0.365 \\
(0.049)^{* * * *}\end{array}$ & $\begin{array}{l}0.245 \\
(0.054)^{* * * *}\end{array}$ & $\begin{array}{l}0.298 \\
(0.052)^{* * * *}\end{array}$ \\
\hline & & Smaller Firm & $\begin{array}{l}-0.534 \\
(0.082)^{* * * *}\end{array}$ & $\begin{array}{l}-0.649 \\
(0.098)^{* * * *}\end{array}$ & $\begin{array}{l}-0.890 \\
(0.095)^{* * * *}\end{array}$ & $\begin{array}{l}-0.510 \\
(0.102)^{* * * *}\end{array}$ & $\begin{array}{c}-0.708 \\
(0.087)^{* * * *}\end{array}$ & $\begin{array}{c}-0.585 \\
(0.089)^{* * * *}\end{array}$ & $\begin{array}{c}-0.621 \\
(0.091)^{* * * *}\end{array}$ & $\begin{array}{c}-0.428 \\
(0.092)^{* * * *}\end{array}$ & $\begin{array}{c}-0.834 \\
(0.079)^{* * * *}\end{array}$ & $\begin{array}{c}-0.502 \\
(0.076)^{* * * *}\end{array}$ & $\begin{array}{c}-0.564 \\
(0.072)^{* * * *}\end{array}$ & $\begin{array}{c}-0.706 \\
(0.064)^{* * * *}\end{array}$ & $\begin{array}{c}-0.559 \\
(0.064)^{* * * *}\end{array}$ & $\begin{array}{l}-0.750 \\
(0.068)^{* * * *}\end{array}$ & $\begin{array}{c}-0.494 \\
(0.067)^{* * * *}\end{array}$ \\
\hline \multirow{3}{*}{ 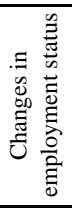 } & \multirow{3}{*}{ 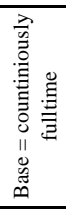 } & continuously partime & $\begin{array}{c}0.318 \\
(0.116)^{* * * *}\end{array}$ & $\begin{array}{r}0.170 \\
(0.148)\end{array}$ & $\begin{array}{r}0.202 \\
(0.133)\end{array}$ & $\begin{array}{r}0.141 \\
(0.118)\end{array}$ & $\begin{array}{c}0.131 \\
(0.108)\end{array}$ & $\begin{array}{l}0.279 \\
(0.113)^{* * *}\end{array}$ & $\begin{array}{l}0.350 \\
(0.112)^{* * * *}\end{array}$ & $\begin{array}{l}0.470 \\
(0.122)^{* * * *}\end{array}$ & $\begin{array}{l}0.652 \\
(0.102)^{* * * *}\end{array}$ & $\begin{array}{l}0.610 \\
(0.08)^{* * * *}\end{array}$ & $\begin{array}{l}0.433 \\
(0.077)^{* * * *}\end{array}$ & $\begin{array}{l}0.527 \\
(0.068)^{* * * *}\end{array}$ & $\begin{array}{l}0.709 \\
(0.065) * * *\end{array}$ & $\begin{array}{l}0.520 \\
(0.072)^{* * * *}\end{array}$ & $\begin{array}{l}0.671 \\
(0.070)^{* * * *}\end{array}$ \\
\hline & & $\begin{array}{l}\text { from partime to } \\
\text { fulltime }\end{array}$ & $\begin{array}{l}1.296 \\
(0.134)^{* * * *}\end{array}$ & $\begin{array}{l}1.584 \\
(0.178)^{* * * *}\end{array}$ & $\begin{array}{l}1.061 \\
(0.169)^{* * * *}\end{array}$ & $\begin{array}{l}1.823 \\
(0.164)^{* * * *}\end{array}$ & $\begin{array}{l}1.357 \\
(0.158)^{* * * *}\end{array}$ & $\begin{array}{l}1.678 \\
(0.150)^{* * * *}\end{array}$ & $\begin{array}{l}1.386 \\
(0.137)^{* * * *}\end{array}$ & $\begin{array}{l}1.890 \\
(0.151)^{* * * *}\end{array}$ & $\begin{array}{l}1.743 \\
(0.144)^{* * * *}\end{array}$ & $\begin{array}{l}1.664 \\
(0.114)^{* * * *}\end{array}$ & $\begin{array}{l}1.738 \\
(0.112)^{* * * *}\end{array}$ & $\begin{array}{l}1.681 \\
(0.092)^{* * * *}\end{array}$ & $\begin{array}{l}1.893 \\
(0.089)^{* * * *}\end{array}$ & $\begin{array}{l}1.712 \\
(0.090)^{* * * *}\end{array}$ & $\begin{array}{l}1.833 \\
(0.091)^{* * * *}\end{array}$ \\
\hline & & $\begin{array}{l}\text { from fulltime to } \\
\text { parttime }\end{array}$ & $\begin{array}{l}-1.533 \\
(0.127)^{* * * *}\end{array}$ & $\begin{array}{l}-1.374 \\
(0.160)^{* * * *}\end{array}$ & $\begin{array}{l}-1.588 \\
(0.150)^{* * * *}\end{array}$ & $\begin{array}{l}-1.556 \\
(0.147)^{* * * *}\end{array}$ & $\begin{array}{l}-1.659 \\
(0.122)^{* * * *}\end{array}$ & $\begin{array}{l}-1.307 \\
(0.112)^{* * * *}\end{array}$ & $\begin{array}{l}-1.271 \\
(0.112)^{* * * *}\end{array}$ & $\begin{array}{l}-1.703 \\
(0.114)^{* * * *}\end{array}$ & $\begin{array}{l}-1.560 \\
(0.102)^{* * * *}\end{array}$ & $\begin{array}{l}-1.319 \\
(0.087)^{* * * *}\end{array}$ & $\begin{array}{l}-1.313 \\
(0.080)^{* * * *}\end{array}$ & $\begin{array}{l}-1.425 \\
(0.071)^{* * * *} \\
\end{array}$ & $\begin{array}{l}-1.382 \\
(0.067)^{* * * *}\end{array}$ & $\begin{array}{l}-1.330 \\
(0.075)^{* * * *}\end{array}$ & $\begin{array}{l}-1.258 \\
(0.078)^{* * * *}\end{array}$ \\
\hline \multicolumn{3}{|c|}{ Female dummy } & $\begin{array}{l}0.137 \\
(0.071)^{*}\end{array}$ & $\begin{array}{c}0.652 \\
(0.088)^{* * * *}\end{array}$ & $\begin{array}{l}0.401 \\
(0.083)^{* * * *}\end{array}$ & $\begin{array}{l}0.644 \\
\left(0.0877^{* * * *}\right.\end{array}$ & $\begin{array}{l}0.358 \\
(0.075)^{* * * *}\end{array}$ & $\begin{array}{l}0.510 \\
(0.079)^{* * * *}\end{array}$ & $\begin{array}{l}0.607 \\
(0.078)^{* * * *}\end{array}$ & $\begin{array}{l}0.606 \\
(0.080)^{* * * *}\end{array}$ & $\begin{array}{l}0.645 \\
(0.075)^{* * * *}\end{array}$ & $\begin{array}{l}0.317 \\
(0.065)^{* * * *}\end{array}$ & $\begin{array}{l}0.428 \\
(0.063)^{* * * *}\end{array}$ & $\begin{array}{l}0.492 \\
(0.055)^{* * * *}\end{array}$ & $\begin{array}{l}0.316 \\
(0.052)^{* * * *}\end{array}$ & $\begin{array}{l}0.395 \\
(0.058)^{* * * *}\end{array}$ & $\begin{array}{l}0.279 \\
(0.057)^{* * * *}\end{array}$ \\
\hline \multirow{3}{*}{ 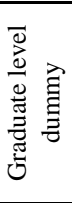 } & \multirow{3}{*}{ 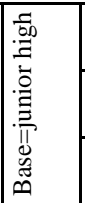 } & High school & $\begin{array}{c}-0.180 \\
(0.095)^{*}\end{array}$ & $\begin{array}{c}-0.052 \\
(0.077)\end{array}$ & $\begin{array}{l}-0.262 \\
(0.078)^{* * * * *}\end{array}$ & $\begin{array}{l}-0.301 \\
(0.079)^{* * * * *}\end{array}$ & $\begin{array}{l}-0.324 \\
(0.070)^{* * * * *}\end{array}$ & $\begin{array}{l}-0.261 \\
(0.075)^{* * * *}\end{array}$ & $\begin{array}{l}-0.303 \\
(0.081)^{*+* * *}\end{array}$ & $\begin{array}{l}-0.374 \\
(0.084)^{* * * * *}\end{array}$ & $\begin{array}{l}-0.377 \\
(0.079)^{* * * * *}\end{array}$ & $\begin{array}{r}-0.094 \\
(0.073)\end{array}$ & $\begin{array}{l}-0.264 \\
(0.069)^{*+* * *}\end{array}$ & $\begin{array}{l}-0.343 \\
(0.069)^{* * * * *}\end{array}$ & $\begin{array}{l}-0.147 \\
(0.068)^{* * *}\end{array}$ & $\begin{array}{c}0.002 \\
(0.073)\end{array}$ & $\begin{array}{r}-0.046 \\
(0.071)\end{array}$ \\
\hline & & Junior college & $\begin{array}{l}-0.480 \\
(0.128)^{* * *}\end{array}$ & $\begin{array}{r}0.035 \\
(0.163)\end{array}$ & $\begin{array}{l}-0.544 \\
(0.152)^{* * * *}\end{array}$ & $\begin{array}{c}-0.055 \\
(0.158)\end{array}$ & $\begin{array}{l}-0.588 \\
(0.139)^{* * * *}\end{array}$ & $\begin{array}{c}-0.230 \\
(0.119)^{*}\end{array}$ & $\begin{array}{r}-0.189 \\
(0.120)\end{array}$ & $\begin{array}{c}-0.222 \\
(0.128)^{*}\end{array}$ & $\begin{array}{r}-0.082 \\
(0.117)\end{array}$ & $\begin{array}{r}-0.143 \\
(0.103)\end{array}$ & $\begin{array}{l}-0.261 \\
(0.100)^{* * * *}\end{array}$ & $\begin{array}{l}-0.218 \\
(0.089)^{* *}\end{array}$ & $\begin{array}{l}-0.190 \\
(0.087)^{* * *}\end{array}$ & $\begin{array}{r}-0.041 \\
(0.094)\end{array}$ & $\begin{array}{r}0.000 \\
(0.092)\end{array}$ \\
\hline & & University & $\begin{array}{c}-0.166 \\
(0.129) \\
\end{array}$ & $\begin{array}{r}0.178 \\
(0.147) \\
\end{array}$ & $\begin{array}{l}-0.441 \\
(0.129)^{* * * *}\end{array}$ & $\begin{array}{c}-0.108 \\
(0.140) \\
\end{array}$ & $\begin{array}{l}-0.352 \\
(0.119)^{* * * * *}\end{array}$ & $\begin{array}{r}-0.106 \\
(0.115) \\
\end{array}$ & $\begin{array}{c}-0.202 \\
(0.119)^{*} \\
\end{array}$ & $\begin{array}{r}-0.119 \\
(0.122) \\
\end{array}$ & $\begin{array}{r}-0.168 \\
(0.115) \\
\end{array}$ & $\begin{array}{r}0.131 \\
(0.104) \\
\end{array}$ & $\begin{array}{r}-0.086 \\
(0.099) \\
\end{array}$ & $\begin{array}{r}-0.149 \\
(0.093)\end{array}$ & $\begin{array}{r}-0.073 \\
(0.089)\end{array}$ & $\begin{array}{r}0.127 \\
(0.094)\end{array}$ & $\begin{array}{l}0.222 \\
(0.092)^{* * *}\end{array}$ \\
\hline \multirow{4}{*}{ 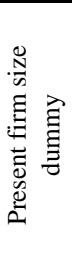 } & \multirow{4}{*}{$\begin{array}{l}\stackrel{2}{N} \\
1 \\
1 \\
11 \\
0 \\
0 \\
0 \\
\infty\end{array}$} & $30-99$ & $\begin{array}{c}-0.230 \\
(0.127)^{*}\end{array}$ & $\begin{array}{l}-0.495 \\
(0.126)^{* * * *}\end{array}$ & $\begin{array}{r}0.013 \\
(0.133)\end{array}$ & $\begin{array}{l}-0.454 \\
(0.133)^{* * * *}\end{array}$ & $\begin{array}{l}-0.482 \\
(0.117)^{* * * *}\end{array}$ & $\begin{array}{l}-0.293 \\
(0.129)^{* * *}\end{array}$ & $\begin{array}{l}-0.319 \\
(0.127)^{* *}\end{array}$ & $\begin{array}{l}-0.454 \\
(0.137)^{* * * *}\end{array}$ & $\begin{array}{r}-0.110 \\
(0.126)\end{array}$ & $\begin{array}{l}-0.304 \\
(0.107)^{* * * *}\end{array}$ & $\begin{array}{l}-0.468 \\
(0.106)^{* * * *}\end{array}$ & $\begin{array}{l}-0.484 \\
(0.092)^{* * * *}\end{array}$ & $\begin{array}{l}-0.395 \\
(0.104)^{* * * *}\end{array}$ & $\begin{array}{l}-0.387 \\
(0.104)^{* * * *}\end{array}$ & $\begin{array}{l}-0.308 \\
(0.111)^{* * * *}\end{array}$ \\
\hline & & $100-299$ & $\begin{array}{l}-0.470 \\
(0.126)^{* * * *}\end{array}$ & $\begin{array}{l}-0.546 \\
(0.130)^{* * * *}\end{array}$ & $\begin{array}{c}-0.244 \\
(0.138)^{*}\end{array}$ & $\begin{array}{l}-0.696 \\
(0.135)^{* * * * *}\end{array}$ & $\begin{array}{l}-0.578 \\
(0.119)^{* * * * *}\end{array}$ & $\begin{array}{l}-0.571 \\
(0.129)^{* * * *}\end{array}$ & $\begin{array}{l}-0.636 \\
(0.126)^{* * * *}\end{array}$ & $\begin{array}{l}-0.500 \\
(0.140)^{* * * *}\end{array}$ & $\begin{array}{l}-0.585 \\
(0.128)^{* * * *}\end{array}$ & $\begin{array}{l}-0.418 \\
(0.106)^{* * * *}\end{array}$ & $\begin{array}{l}-0.777 \\
(0.106)^{*+* * *}\end{array}$ & $\begin{array}{l}-0.565 \\
(0.094)^{* * * *}\end{array}$ & $\begin{array}{l}-0.677 \\
(0.106)^{* * * *}\end{array}$ & $\begin{array}{l}-0.776 \\
(0.103)^{* * * *}\end{array}$ & $\begin{array}{l}-0.458 \\
(0.108)^{* * * *}\end{array}$ \\
\hline & & 300 - 999 & $\begin{array}{l}-0.589 \\
(0.130)^{* * * *}\end{array}$ & $\begin{array}{l}-0.649 \\
(0.140)^{* * * *}\end{array}$ & $\begin{array}{l}-0.268 \\
(0.149)^{*}\end{array}$ & $\begin{array}{l}-0.504 \\
(0.146)^{* * * *}\end{array}$ & $\begin{array}{l}-0.945 \\
(0.128)^{* * * *}\end{array}$ & $\begin{array}{l}-0.682 \\
(0.135)^{* * * *}\end{array}$ & $\begin{array}{l}-0.574 \\
(0.133)^{* * * *}\end{array}$ & $\begin{array}{l}-0.598 \\
(0.147)^{* * * *}\end{array}$ & $\begin{array}{l}-0.464 \\
(0.137)^{* * * *}\end{array}$ & $\begin{array}{l}-0.459 \\
(0.115)^{* * * *}\end{array}$ & $\begin{array}{l}-0.655 \\
(0.110)^{* * * *}\end{array}$ & $\begin{array}{l}-0.621 \\
(0.101)^{* * * *}\end{array}$ & $\begin{array}{l}-0.707 \\
(0.109)^{* * * *}\end{array}$ & $\begin{array}{l}-0.641 \\
(0.107)^{* * * *}\end{array}$ & $\begin{array}{l}-0.384 \\
(0.112)^{* * * *}\end{array}$ \\
\hline & & over 1000 & $\begin{array}{l}-0.325 \\
(0.134)^{* * *}\end{array}$ & $\begin{array}{l}-0.484 \\
\left(0.1477^{*+*}\right.\end{array}$ & $\begin{array}{c}-0.165 \\
(0.148)\end{array}$ & $\begin{array}{l}-0.328 \\
(0.150)^{* *}\end{array}$ & $\begin{array}{l}-0.568 \\
(0.130)^{*+* * *}\end{array}$ & $\begin{array}{l}-0.417 \\
(0.137)^{* * * *}\end{array}$ & $\begin{array}{l}-0.617 \\
(0.136)^{* * * *}\end{array}$ & $\begin{array}{c}-0.316 \\
(0.148)^{* * *}\end{array}$ & $\begin{array}{c}-0.491 \\
(0.136)^{* * * *}\end{array}$ & $\begin{array}{c}-0.439 \\
(0.114)^{* * * *}\end{array}$ & $\begin{array}{c}-0.763 \\
(0.111)^{* * * *}\end{array}$ & $\begin{array}{c}-0.855 \\
(0.100)^{* * * *}\end{array}$ & $\begin{array}{l}-0.919 \\
(0.110)^{* * * *}\end{array}$ & $\begin{array}{c}-0.728 \\
(0.107)^{*+* * *}\end{array}$ & $\begin{array}{c}-0.379 \\
(0.113)^{* * * *}\end{array}$ \\
\hline & & Construction & $\begin{array}{c}0.300 \\
(0.270)\end{array}$ & $\begin{array}{c}0.593 \\
(0.203)^{* * * *}\end{array}$ & $\begin{array}{c}-0.246 \\
(0.253)\end{array}$ & $\begin{array}{l}0.474 \\
(0.271)^{*}\end{array}$ & $\begin{array}{l}1.107 \\
(0.339)^{* * * *}\end{array}$ & $\begin{array}{c}0.158 \\
(0.240)\end{array}$ & $\begin{array}{r}-0.108 \\
(0.252)\end{array}$ & $\begin{array}{c}0.232 \\
(0.294)\end{array}$ & $\begin{array}{l}0.605 \\
(0.304)^{* * *}\end{array}$ & $\begin{array}{r}0.196 \\
(0.263)\end{array}$ & $\begin{array}{r}-0.392 \\
(0.299)\end{array}$ & $\begin{array}{c}0.186 \\
(0.230)\end{array}$ & $\begin{array}{r}-0.036 \\
(0.250)\end{array}$ & $\begin{array}{l}0.848 \\
(0.313)^{* * * *}\end{array}$ & $\begin{array}{r}-0.153 \\
(0.292)\end{array}$ \\
\hline
\end{tabular}




\begin{tabular}{|c|c|c|c|c|c|c|c|c|c|c|c|c|c|c|c|c|c|}
\hline \multirow{7}{*}{ 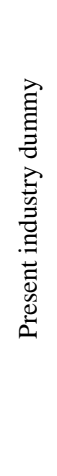 } & \multirow{7}{*}{ 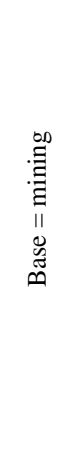 } & Manufacturing & $\begin{array}{c}-0.212 \\
(0.230)\end{array}$ & $\begin{array}{r}0.189 \\
(0.186)\end{array}$ & $\begin{array}{l}-0.556 \\
(0.239)^{* * *}\end{array}$ & $\begin{array}{r}0.121 \\
(0.252)\end{array}$ & $\begin{array}{l}0.812 \\
(0.333)^{* * *}\end{array}$ & $\begin{array}{r}-0.354 \\
(0.231)\end{array}$ & $\begin{array}{c}-0.561 \\
(0.246)^{* * *}\end{array}$ & $\begin{array}{r}-0.073 \\
(0.287)\end{array}$ & $\begin{array}{r}-0.039 \\
(0.290)\end{array}$ & $\begin{array}{c}-0.604 \\
(0.253)^{* * *}\end{array}$ & $\begin{array}{c}-0.888 \\
(0.290)^{* * * * *}\end{array}$ & $\begin{array}{r}-0.289 \\
(0.218)\end{array}$ & $\begin{array}{c}-0.455 \\
(0.237)^{*}\end{array}$ & $\begin{array}{r}0.414 \\
(0.300)\end{array}$ & $\begin{array}{c}-0.477 \\
(0.274)^{*}\end{array}$ \\
\hline & & Electricity/gas & $\begin{array}{r}0.173 \\
(0.382)\end{array}$ & $\begin{array}{l}-0.786 \\
\left(0.2911^{* * * *}\right.\end{array}$ & $\begin{array}{l}-1.068 \\
\left(0.3166^{* * * *}\right.\end{array}$ & $\begin{array}{r}0.266 \\
(0.371)\end{array}$ & $\begin{array}{c}0.054 \\
(0.411)\end{array}$ & $\begin{array}{l}-1.355 \\
(0.347)^{* * * *}\end{array}$ & $\begin{array}{c}-0.851 \\
(0.463)^{*}\end{array}$ & $\begin{array}{r}-0.282 \\
(0.447)\end{array}$ & $\begin{array}{l}-1.379 \\
(0.426)^{* * * *}\end{array}$ & $\begin{array}{l}-1.279 \\
\left(0.4211^{* * * *}\right.\end{array}$ & $\begin{array}{l}-2.000 \\
(0.402)^{* * * *}\end{array}$ & $\begin{array}{l}-0.987 \\
\left(0.2922^{* * * *}\right.\end{array}$ & $\begin{array}{c}-0.993 \\
(0.322)^{* * * *}\end{array}$ & $\begin{array}{r}-0.735 \\
(0.382)^{*}\end{array}$ & $\begin{array}{l}-1.045 \\
(0.357 * * * *\end{array}$ \\
\hline & & $\begin{array}{l}\text { Communication/ } \\
\text { transportation }\end{array}$ & $\begin{array}{r}-0.208 \\
(0.301)\end{array}$ & $\begin{array}{r}0.253 \\
(0.322)\end{array}$ & $\begin{array}{l}-0.575 \\
(0.290)^{* * *}\end{array}$ & $\begin{array}{r}0.285 \\
(0.306)\end{array}$ & $\begin{array}{c}0.595 \\
(0.385)\end{array}$ & $\begin{array}{r}-0.552 \\
(0.282)^{*}\end{array}$ & $\begin{array}{r}-0.327 \\
(0.284)\end{array}$ & $\begin{array}{r}-0.194 \\
(0.320)\end{array}$ & $\begin{array}{r}-0.068 \\
(0.330)\end{array}$ & $\begin{array}{l}-0.642 \\
(0.28)^{* * *}\end{array}$ & $\begin{array}{r}-0.445 \\
(0.337)\end{array}$ & $\begin{array}{r}-0.241 \\
(0.249)\end{array}$ & $\begin{array}{r}-0.475 \\
(0.262)^{*}\end{array}$ & $\begin{array}{r}0.282 \\
(0.315)\end{array}$ & $\begin{array}{l}-0.578 \\
(0.281)^{* * *}\end{array}$ \\
\hline & & $\begin{array}{c}\text { Wholesale/ retail/ } \\
\text { restaurants }\end{array}$ & $\begin{array}{r}-0.317 \\
(0.273)\end{array}$ & $\begin{array}{c}-0.060 \\
(0.290)\end{array}$ & $\begin{array}{c}-0.080 \\
(0.304)\end{array}$ & $\begin{array}{c}-0.423 \\
(0.341)\end{array}$ & $\begin{array}{c}0.728 \\
(0.381)^{*}\end{array}$ & $\begin{array}{r}-0.238 \\
(0.288)\end{array}$ & $\begin{array}{l}-0.886 \\
(0.301)^{* * * *}\end{array}$ & $\begin{array}{r}-0.183 \\
(0.336)\end{array}$ & $\begin{array}{r}-0.198 \\
(0.323)\end{array}$ & $\begin{array}{l}-0.860 \\
(0.283)^{* * * *}\end{array}$ & $\begin{array}{l}-0.941 \\
(0.317)^{* * *}\end{array}$ & $\begin{array}{r}-0.318 \\
(0.241)\end{array}$ & $\begin{array}{l}-0.620 \\
(0.252)^{* * *}\end{array}$ & $\begin{array}{r}0.089 \\
(0.313)\end{array}$ & $\begin{array}{l}-0.562 \\
(0.286)^{* * *}\end{array}$ \\
\hline & & Finance/ insurance & $\begin{array}{r}-0.641 \\
(0.342)^{*}\end{array}$ & $\begin{array}{l}-0.763 \\
(0.331)^{* * *}\end{array}$ & $\begin{array}{l}-0.820 \\
(0.345)^{* * *}\end{array}$ & $\begin{array}{c}-0.400 \\
(0.346)\end{array}$ & $\begin{array}{r}0.142 \\
(0.402)\end{array}$ & $\begin{array}{r}-0.532 \\
(0.301)^{*}\end{array}$ & $\begin{array}{l}-0.827 \\
(0.293)^{* * * *}\end{array}$ & $\begin{array}{r}-0.060 \\
(0.322)\end{array}$ & $\begin{array}{r}-0.321 \\
(0.361)\end{array}$ & $\begin{array}{r}-0.320 \\
(0.310)\end{array}$ & $\begin{array}{l}-0.855 \\
(0.326)^{* * * *}\end{array}$ & $\begin{array}{r}-0.240 \\
(0.259)\end{array}$ & $\begin{array}{r}-0.352 \\
(0.285)\end{array}$ & $\begin{array}{r}0.499 \\
(0.342)\end{array}$ & $\begin{array}{r}-0.568 \\
(0.321)^{*}\end{array}$ \\
\hline & & Real estate & $\begin{array}{c}-0.369 \\
(0.419)\end{array}$ & $\begin{array}{c}-0.359 \\
(0.265)\end{array}$ & $\begin{array}{c}-0.450 \\
(0.309)\end{array}$ & $\begin{array}{r}0.225 \\
(0.326)\end{array}$ & $\begin{array}{c}0.666 \\
(0.379)^{*}\end{array}$ & $\begin{array}{c}-0.564 \\
(0.279)^{* * *}\end{array}$ & $\begin{array}{c}-0.621 \\
(0.286)^{* * *}\end{array}$ & $\begin{array}{r}-0.280 \\
(0.325)\end{array}$ & $\begin{array}{r}-0.412 \\
(0.330)\end{array}$ & $\begin{array}{c}-0.521 \\
(0.284)^{*}\end{array}$ & $\begin{array}{l}-1.291 \\
(0.325)^{* * * *}\end{array}$ & $\begin{array}{r}-0.324 \\
(0.272)\end{array}$ & $\begin{array}{c}-0.618 \\
(0.290)^{* * *}\end{array}$ & $\begin{array}{r}-0.029 \\
(0.337)\end{array}$ & $\begin{array}{r}-0.349 \\
(0.308)\end{array}$ \\
\hline & & Service & $\begin{array}{r}-0.441 \\
(0.237)^{*}\end{array}$ & $\begin{array}{r}0.058 \\
(0.190) \\
\end{array}$ & $\begin{array}{l}-0.492 \\
(0.243)^{* * *}\end{array}$ & $\begin{array}{c}-0.207 \\
(0.260) \\
\end{array}$ & $\begin{array}{l}0.748 \\
(0.337)^{* *}\end{array}$ & $\begin{array}{r}-0.324 \\
(0.236) \\
\end{array}$ & $\begin{array}{c}-0.628 \\
(0.25)^{* * *}\end{array}$ & $\begin{array}{r}-0.071 \\
(0.290) \\
\end{array}$ & $\begin{array}{r}-0.097 \\
(0.290) \\
\end{array}$ & $\begin{array}{l}-0.705 \\
(0.254)^{* * * *} \\
\end{array}$ & $\begin{array}{l}-0.836 \\
(0.291)^{* * *}\end{array}$ & $\begin{array}{r}-0.395 \\
(0.220)^{*}\end{array}$ & $\begin{array}{c}-0.519 \\
(0.236)^{* * *}\end{array}$ & $\begin{array}{r}0.331 \\
(0.304) \\
\end{array}$ & $\begin{array}{r}-0.366 \\
(0.275) \\
\end{array}$ \\
\hline \multirow{6}{*}{ 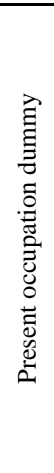 } & \multirow{6}{*}{ 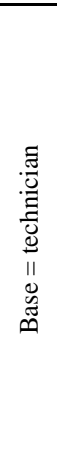 } & Manager & $\begin{array}{l}0.380 \\
(0.208)^{*}\end{array}$ & $\begin{array}{c}-0.358 \\
(0.192)^{*}\end{array}$ & $\begin{array}{c}-0.300 \\
(0.164)^{*}\end{array}$ & $\begin{array}{c}-0.346 \\
(0.17)^{*}\end{array}$ & $\begin{array}{c}-0.555 \\
(0.152)^{* * * *}\end{array}$ & $\begin{array}{r}-0.201 \\
(0.145)\end{array}$ & $\begin{array}{r}-0.031 \\
(0.152)\end{array}$ & $\begin{array}{c}-0.386 \\
(0.151)^{* * *}\end{array}$ & $\begin{array}{r}-0.106 \\
(0.140)\end{array}$ & $\begin{array}{l}-0.340 \\
(0.128)^{* * * *}\end{array}$ & $\begin{array}{l}-0.349 \\
(0.128)^{* * * *}\end{array}$ & $\begin{array}{r}-0.060 \\
(0.112)\end{array}$ & $\begin{array}{c}-0.205 \\
(0.115)^{*}\end{array}$ & $\begin{array}{c}0.000 \\
(0.113)\end{array}$ & $\begin{array}{r}0.053 \\
(0.116)\end{array}$ \\
\hline & & Administration & $\begin{array}{l}-0.335 \\
(0.099)^{* * * *}\end{array}$ & $\begin{array}{c}-0.234 \\
(0.169)\end{array}$ & $\begin{array}{l}-0.631 \\
(0.147)^{* * * *}\end{array}$ & $\begin{array}{l}-0.532 \\
(0.166)^{* * * *}\end{array}$ & $\begin{array}{r}-0.214 \\
(0.141)\end{array}$ & $\begin{array}{l}-0.769 \\
(0.134)^{* * * *}\end{array}$ & $\begin{array}{l}-0.573 \\
\left(0.1333^{* * * *}\right.\end{array}$ & $\begin{array}{l}-0.687 \\
(0.131)^{* * * *}\end{array}$ & $\begin{array}{l}-0.437 \\
(0.127)^{* * * *}\end{array}$ & $\begin{array}{l}-0.286 \\
(0.108)^{* * * *}\end{array}$ & $\begin{array}{l}-0.407 \\
(0.104)^{* * * *}\end{array}$ & $\begin{array}{l}-0.596 \\
\left(0.0877^{* * * *}\right.\end{array}$ & $\begin{array}{l}-0.400 \\
(0.086)^{* * * *}\end{array}$ & $\begin{array}{l}-0.346 \\
(0.090)^{* * * *}\end{array}$ & $\begin{array}{c}-0.176 \\
(0.087)^{* * *}\end{array}$ \\
\hline & & Sales & $\begin{array}{c}-0.012 \\
(0.153)\end{array}$ & $\begin{array}{c}-0.262 \\
(0.282)\end{array}$ & $\begin{array}{c}-0.255 \\
(0.236)\end{array}$ & $\begin{array}{l}0.520 \\
(0.267)^{*}\end{array}$ & $\begin{array}{r}0.105 \\
(0.204)\end{array}$ & $\begin{array}{r}-0.015 \\
(0.197)\end{array}$ & $\begin{array}{r}-0.025 \\
(0.217)\end{array}$ & $\begin{array}{r}-0.321 \\
(0.184)^{*}\end{array}$ & $\begin{array}{r}0.038 \\
(0.177)\end{array}$ & $\begin{array}{l}-0.316 \\
(0.153)^{* *}\end{array}$ & $\begin{array}{r}0.006 \\
(0.149)\end{array}$ & $\begin{array}{r}-0.207 \\
(0.125)^{*}\end{array}$ & $\begin{array}{r}-0.024 \\
(0.118)\end{array}$ & $\begin{array}{r}0.028 \\
(0.133)\end{array}$ & $\begin{array}{r}0.136 \\
(0.124)\end{array}$ \\
\hline & & Service & $\begin{array}{r}0.082 \\
(0.251)\end{array}$ & $\begin{array}{c}0.484 \\
(0.185)^{* * * *}\end{array}$ & $\begin{array}{r}-0.032 \\
(0.155)\end{array}$ & $\begin{array}{l}0.303 \\
(0.173)^{*}\end{array}$ & $\begin{array}{r}0.226 \\
(0.146)\end{array}$ & $\begin{array}{c}0.014 \\
(0.146)\end{array}$ & $\begin{array}{r}-0.099 \\
(0.152)\end{array}$ & $\begin{array}{c}0.127 \\
(0.150)\end{array}$ & $\begin{array}{c}0.003 \\
(0.136)\end{array}$ & $\begin{array}{c}0.052 \\
(0.118)\end{array}$ & $\begin{array}{c}0.120 \\
(0.111)\end{array}$ & $\begin{array}{r}0.026 \\
(0.094)\end{array}$ & $\begin{array}{c}0.136 \\
(0.096)\end{array}$ & $\begin{array}{l}0.403 \\
(0.109)^{* * * *}\end{array}$ & $\begin{array}{c}0.086 \\
(0.109)\end{array}$ \\
\hline & & Production & $\begin{array}{l}0.279 \\
(0.127)^{* * *}\end{array}$ & $\begin{array}{c}0.587 \\
(0.164)^{* * * *}\end{array}$ & $\begin{array}{r}0.073 \\
(0.138)\end{array}$ & $\begin{array}{r}0.240 \\
(0.156)\end{array}$ & $\begin{array}{c}0.278 \\
(0.132)^{* * *}\end{array}$ & $\begin{array}{c}0.178 \\
(0.126)\end{array}$ & $\begin{array}{l}0.346 \\
(0.128)^{* * * *}\end{array}$ & $\begin{array}{c}0.273 \\
(0.130)^{* * *}\end{array}$ & $\begin{array}{r}0.171 \\
(0.115)\end{array}$ & $\begin{array}{l}0.197 \\
(0.100)^{* * *}\end{array}$ & $\begin{array}{r}0.089 \\
(0.095)\end{array}$ & $\begin{array}{l}0.158 \\
(0.080)^{* * *}\end{array}$ & $\begin{array}{r}0.006 \\
(0.080)\end{array}$ & $\begin{array}{r}0.030 \\
(0.084)\end{array}$ & $\begin{array}{l}0.294 \\
(0.079)^{* * * *}\end{array}$ \\
\hline & & Others & $\begin{array}{r}-0.092 \\
(0.098)\end{array}$ & $\begin{array}{r}0.164 \\
(0.174)\end{array}$ & $\begin{array}{c}-0.045 \\
(0.149)\end{array}$ & $\begin{array}{l}0.424 \\
(0.165)^{* * *}\end{array}$ & $\begin{array}{r}0.071 \\
(0.145)\end{array}$ & $\begin{array}{c}-0.277 \\
(0.141)^{*}\end{array}$ & $\begin{array}{c}-0.257 \\
(0.147)^{*}\end{array}$ & $\begin{array}{r}-0.042 \\
(0.154)\end{array}$ & $\begin{array}{c}0.280 \\
(0.151)^{*}\end{array}$ & $\begin{array}{l}0.310 \\
(0.13)^{* *}\end{array}$ & $\begin{array}{l}0.570 \\
(0.125)^{* * * *}\end{array}$ & $\begin{array}{r}-0.084 \\
(0.113)\end{array}$ & $\begin{array}{r}0.046 \\
(0.112)\end{array}$ & $\begin{array}{c}0.254 \\
(0.131)^{*}\end{array}$ & $\begin{array}{r}0.135 \\
(0.153)\end{array}$ \\
\hline \multirow{5}{*}{ 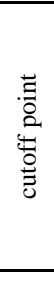 } & & $\mathrm{TAU}_{30}$ & $\begin{array}{l}-3.393 \\
\left(0.4311^{* * * *}\right.\end{array}$ & $\begin{array}{l}-3.560 \\
(0.475)^{* * * *}\end{array}$ & $\begin{array}{l}-4.886 \\
(0.481)^{* * * *}\end{array}$ & $\begin{array}{l}-3.019 \\
(0.505)^{* * * *}\end{array}$ & $\begin{array}{l}-3.519 \\
(0.506)^{* * * *}\end{array}$ & $\begin{array}{c}-5.329 \\
(0.442 * * *\end{array}$ & $\begin{array}{l}-4.283 \\
\left(0.4466^{* * * *}\right.\end{array}$ & $\begin{array}{l}-4.475 \\
(0.501)^{* * * *}\end{array}$ & $\begin{array}{l}-3.389 \\
(0.489) * * *\end{array}$ & $\begin{array}{l}-4.052 \\
(0.410)^{* * * *}\end{array}$ & $\begin{array}{l}-4.448 \\
(0.430)^{* * * *}\end{array}$ & $\begin{array}{l}-4.267 \\
(0.354)^{* * * *}\end{array}$ & $\begin{array}{l}-4.725 \\
(0.363)^{* * * *}\end{array}$ & $\begin{array}{l}-3.709 \\
(0.426)^{* * * *}\end{array}$ & $\begin{array}{c}-3.766 \\
(0.396) * * *\end{array}$ \\
\hline & & $\mathrm{TAU}_{15}$ & $\begin{array}{l}-1.727 \\
(0.428)^{* * * *}\end{array}$ & $\begin{array}{l}-2.447 \\
(0.473)^{* * * * *}\end{array}$ & $\begin{array}{l}-3.574 \\
(0.479)^{* * * *}\end{array}$ & $\begin{array}{l}-1.641 \\
(0.502)^{* * * * *}\end{array}$ & $\begin{array}{l}-2.145 \\
(0.505)^{* * * *}\end{array}$ & $\begin{array}{l}-3.997 \\
(0.439)^{* * * * *}\end{array}$ & $\begin{array}{l}-2.954 \\
(0.444)^{* * *}\end{array}$ & $\begin{array}{l}-3.307 \\
(0.500)^{* * * *}\end{array}$ & $\begin{array}{l}-2.232 \\
(0.488)^{* * * *}\end{array}$ & $\begin{array}{l}-2.911 \\
(0.409)^{* * * *}\end{array}$ & $\begin{array}{l}-3.446 \\
(0.429)^{* * * *}\end{array}$ & $\begin{array}{l}-3.152 \\
(0.353)^{* * *}\end{array}$ & $\begin{array}{l}-3.581 \\
(0.362)^{* * * *}\end{array}$ & $\begin{array}{l}-2.572 \\
(0.425)^{* * * *}\end{array}$ & $\begin{array}{c}-2.593 \\
(0.395)^{* * * *}\end{array}$ \\
\hline & & $\mathrm{TAU}_{0}$ & $\begin{array}{r}0.339 \\
(0.428)\end{array}$ & $\begin{array}{l}1.018 \\
(0.472)^{* * *}\end{array}$ & $\begin{array}{c}-0.255 \\
(0.474)\end{array}$ & $\begin{array}{l}1.487 \\
(0.502)^{* * * *}\end{array}$ & $\begin{array}{l}1.010 \\
(0.504)^{* * *}\end{array}$ & $\begin{array}{r}-0.848 \\
(0.435)^{*}\end{array}$ & $\begin{array}{r}0.057 \\
(0.441)\end{array}$ & $\begin{array}{c}0.871 \\
(0.496)^{*}\end{array}$ & $\begin{array}{l}1.657 \\
(0.486)^{* * * *}\end{array}$ & $\begin{array}{l}0.867 \\
(0.405)^{* * *}\end{array}$ & $\begin{array}{r}0.422 \\
(0.425)\end{array}$ & $\begin{array}{r}0.465 \\
(0.350)\end{array}$ & $\begin{array}{c}0.090 \\
(0.358)\end{array}$ & $\begin{array}{l}0.934 \\
(0.422)^{* * *}\end{array}$ & $\begin{array}{c}0.764 \\
(0.392)^{*}\end{array}$ \\
\hline & & $\mathrm{TAU}_{-15}$ & $\begin{array}{l}2.574 \\
(0.435)^{* * * *}\end{array}$ & $\begin{array}{c}3.709 \\
(0.490)^{* * * *}\end{array}$ & $\begin{array}{c}2.080 \\
(0.486)^{* * * *}\end{array}$ & $\begin{array}{c}3.525 \\
(0.512)^{* * * *}\end{array}$ & $\begin{array}{l}3.239 \\
(0.512)^{* * * * *}\end{array}$ & $\begin{array}{l}1.146 \\
(0.441)^{* * * *}\end{array}$ & $\begin{array}{l}2.239 \\
(0.450)^{* * * * *}\end{array}$ & $\begin{array}{l}2.600 \\
(0.505)^{* * * * *}\end{array}$ & $\begin{array}{l}3.514 \\
(0.497)^{* * * *}\end{array}$ & $\begin{array}{l}2.317 \\
(0.411)^{* * * *}\end{array}$ & $\begin{array}{l}1.971 \\
(0.430)^{* * * *}\end{array}$ & $\begin{array}{l}2.071 \\
(0.354)^{* * * * *}\end{array}$ & $\begin{array}{l}1.643 \\
(0.362)^{* * * * *}\end{array}$ & $\begin{array}{l}2.454 \\
(0.425)^{* * * *}\end{array}$ & $\begin{array}{l}2.424 \\
(0.395)^{*+* * *}\end{array}$ \\
\hline & \multicolumn{2}{|c|}{ bservations } & 4463 & 4256 & 4397 & 4010 & 5248 & 4928 & 4806 & 5238 & 5616 & 7002 & 7759 & 9650 & 10064 & 8640 & 8583 \\
\hline
\end{tabular}

Standard errors in parentheses 
Appendix 2b: Results of Ordered Logit (Voluntary Separation Sample)

\begin{tabular}{|c|c|c|c|c|c|c|c|c|c|c|c|c|c|c|c|c|c|}
\hline & \multirow{2}{*}{\multicolumn{2}{|c|}{ Dependent variable }} & (16) & (17) & (18) & (19) & (20) & $(21)$ & $(22)$ & (23) & $(24)$ & $(25)$ & $(26)$ & $(27)$ & $(28)$ & (29) & $(30)$ \\
\hline & & & \multicolumn{15}{|c|}{ Wage variation (five categories: $-30,-15,0 \%, 1:+10,+30$ ) } \\
\hline \multirow{2}{*}{\multicolumn{3}{|c|}{ Data }} & 1991 & 1992 & 993 & 1994 & 1995 & 1996 & 1997 & 1998 & 1999 & 2000 & 2001 & 2002 & 2003 & 2004 & 2005 \\
\hline & & & \multicolumn{15}{|c|}{ Voluntary Separations } \\
\hline \multicolumn{3}{|c|}{ Estimation method } & \multicolumn{15}{|c|}{ Ordered Logit } \\
\hline \multicolumn{3}{|c|}{ Control } & \multicolumn{15}{|c|}{ prefecture } \\
\hline \multicolumn{3}{|r|}{ Age } & $\begin{array}{l}0.061 \\
(0.005)^{* * * *}\end{array}$ & $\begin{array}{l}0.014 \\
(0.006)^{* * *}\end{array}$ & $\begin{array}{r}0.011 \\
(0.007)\end{array}$ & $\begin{array}{r}0.011 \\
(0.007)\end{array}$ & $\begin{array}{r}-0.005 \\
(0.007)\end{array}$ & $\begin{array}{r}-0.011 \\
(0.007)^{*}\end{array}$ & $\begin{array}{r}0.003 \\
(0.006)\end{array}$ & $\begin{array}{l}-0.027 \\
(0.007)^{* * * *}\end{array}$ & $\begin{array}{c}-0.020 \\
(0.008)^{* * *}\end{array}$ & $\begin{array}{r}-0.014 \\
(0.008)^{*}\end{array}$ & $\begin{array}{r}-0.006 \\
(0.008)\end{array}$ & $\begin{array}{c}-0.035 \\
(0.008)^{* * * *}\end{array}$ & $\begin{array}{r}0.001 \\
(0.008)\end{array}$ & $\begin{array}{c}-0.022 \\
(0.008)^{* * * *}\end{array}$ & $\begin{array}{r}-0.014 \\
(0.008)^{*}\end{array}$ \\
\hline \multicolumn{3}{|r|}{$\operatorname{Age}^{2}$} & $\begin{array}{c}-0.114 \\
(0.007)^{* * *}\end{array}$ & $\begin{array}{l}-0.037 \\
(0.008)^{* * * *}\end{array}$ & $\begin{array}{c}-0.035 \\
(0.009)^{* * *}\end{array}$ & $\begin{array}{l}-0.037 \\
(0.009)^{* * * *}\end{array}$ & $\begin{array}{c}-0.017 \\
(0.009)^{*}\end{array}$ & $\begin{array}{r}-0.011 \\
(0.008)\end{array}$ & $\begin{array}{l}-0.031 \\
(0.008)^{* * *}\end{array}$ & $\begin{array}{r}0.005 \\
(0.010)\end{array}$ & $\begin{array}{r}-0.010 \\
(0.010)\end{array}$ & $\begin{array}{r}-0.013 \\
(0.010)\end{array}$ & $\begin{array}{c}-0.022 \\
(0.010)^{* *}\end{array}$ & $\begin{array}{r}0.012 \\
(0.011)\end{array}$ & $\begin{array}{l}-0.029 \\
(0.010)^{* * * *}\end{array}$ & $\begin{array}{r}-0.007 \\
(0.010)\end{array}$ & $\begin{array}{r}-0.015 \\
(0.010)\end{array}$ \\
\hline \multirow{3}{*}{ 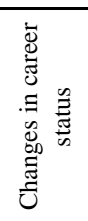 } & \multirow{3}{*}{ 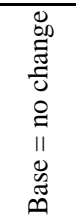 } & Indus & $\begin{array}{c}-0.049 \\
(0.026)^{*}\end{array}$ & $\begin{array}{c}-0.164 \\
(0.030)^{* * *}\end{array}$ & $\begin{array}{c}-0.186 \\
(0.034)^{* * * *}\end{array}$ & $\begin{array}{c}-0.169 \\
(0.036)^{* * * *}\end{array}$ & $\begin{array}{c}-0.115 \\
(0.035)^{* * *}\end{array}$ & $\begin{array}{l}-0.109 \\
(0.031)^{* * * *}\end{array}$ & $\begin{array}{c}-0.112 \\
(0.029)^{* * *}\end{array}$ & $\begin{array}{l}-0.106 \\
(0.035)^{* * * *}\end{array}$ & $\begin{array}{c}-0.098 \\
(0.036)^{* * *}\end{array}$ & $\begin{array}{r}-0.044 \\
(0.033)\end{array}$ & $\begin{array}{r}0.007 \\
(0.033)\end{array}$ & $\begin{array}{r}-0.046 \\
(0.036)\end{array}$ & $\begin{array}{r}0.003 \\
(0.034)\end{array}$ & $\begin{array}{r}0.006 \\
(0.033)\end{array}$ & $\begin{array}{c}0.009 \\
(0.031)\end{array}$ \\
\hline & & Осcul & $\begin{array}{c}-0.203 \\
(0.042)^{* * *}\end{array}$ & $\begin{array}{l}-0.231 \\
(0.044)^{* * * *}\end{array}$ & $\begin{array}{l}-0.256 \\
(0.051)^{* * * *}\end{array}$ & $\begin{array}{l}-0.217 \\
(0.055) * * *\end{array}$ & $\begin{array}{c}-0.215 \\
(0.051)^{* * *}\end{array}$ & $\begin{array}{c}-0.205 \\
(0.046)^{* * * *}\end{array}$ & $\begin{array}{c}-0.235 \\
(0.043) * * *\end{array}$ & $\begin{array}{c}-0.180 \\
(0.051)^{* * * *}\end{array}$ & $\begin{array}{c}-0.382 \\
(0.053)^{* * * *}\end{array}$ & $\begin{array}{l}-0.191 \\
(0.050) * * *\end{array}$ & $\begin{array}{l}-0.141 \\
(0.050)^{* * * *}\end{array}$ & $\begin{array}{c}-0.186 \\
(0.052)^{* * * *}\end{array}$ & $\begin{array}{c}-0.117 \\
(0.049)^{* *}\end{array}$ & $\begin{array}{c}-0.161 \\
(0.048) * * *\end{array}$ & $\begin{array}{c}-0.150 \\
(0.048)^{* * *}\end{array}$ \\
\hline & & Career Change & $\begin{array}{l}-0.096 \\
(0.025)^{* * * *}\end{array}$ & $\begin{array}{l}-0.159 \\
(0.027)^{* * * *}\end{array}$ & $\begin{array}{c}-0.125 \\
(0.030)^{* * * *}\end{array}$ & $\begin{array}{c}-0.155 \\
(0.032)^{* * * *}\end{array}$ & $\begin{array}{c}-0.098 \\
(0.031)^{* * *}\end{array}$ & $\begin{array}{l}-0.119 \\
(0.028)^{* * * *}\end{array}$ & $\begin{array}{c}-0.143 \\
(0.026) * * *\end{array}$ & $\begin{array}{c}-0.134 \\
(0.032) * * *\end{array}$ & $\begin{array}{l}-0.131 \\
(0.034)^{* * * *}\end{array}$ & $\begin{array}{l}-0.101 \\
(0.031)^{* * * *}\end{array}$ & $\begin{array}{c}-0.061 \\
(0.032)^{*}\end{array}$ & $\begin{array}{l}-0.130 \\
(0.035)^{* * * *}\end{array}$ & $\begin{array}{l}-0.129 \\
(0.033)^{* * * *}\end{array}$ & $\begin{array}{c}-0.053 \\
(0.031)^{*}\end{array}$ & $\begin{array}{l}-0.080 \\
(0.031)^{* * *}\end{array}$ \\
\hline \multirow{2}{*}{ 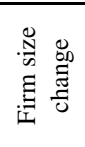 } & \multirow{2}{*}{ 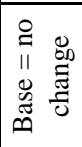 } & $\mathrm{m}$ & $\begin{array}{l}0.424 \\
(0.024)^{* * *}\end{array}$ & $\begin{array}{l}0.436 \\
(0.026)^{* * * *}\end{array}$ & $\begin{array}{l}0.393 \\
(0.030)^{* * *}\end{array}$ & $\begin{array}{l}0.237 \\
(0.032)^{* * * *}\end{array}$ & $\begin{array}{l}0.293 \\
(0.031)^{* * *}\end{array}$ & $\begin{array}{l}0.286 \\
(0.028)^{* * * *}\end{array}$ & $\begin{array}{l}0.340 \\
(0.026)^{* * * *}\end{array}$ & $\begin{array}{l}0.244 \\
(0.031)^{* * * *}\end{array}$ & $\begin{array}{l}0.246 \\
(0.033)^{* * *}\end{array}$ & $\begin{array}{l}0.298 \\
(0.031)^{* * * *}\end{array}$ & $\begin{array}{l}0.336 \\
(0.031)^{* * * *}\end{array}$ & $\begin{array}{l}0.344 \\
(0.033)^{* * * *}\end{array}$ & $\begin{array}{l}0.299 \\
(0.031)^{* * * *}\end{array}$ & $\begin{array}{l}0.235 \\
(0.030)^{* * * *}\end{array}$ & $\begin{array}{l}0.273 \\
(0.029) * * *\end{array}$ \\
\hline & & $\mathrm{S}$ & $\begin{array}{c}-0.451 \\
(0.033)^{* * *}\end{array}$ & $\begin{array}{l}-0.478 \\
(0.036)^{* * *}\end{array}$ & $\begin{array}{l}-0.444 \\
(0.039)^{* * *}\end{array}$ & $\begin{array}{l}-0.516 \\
(0.042)^{* * * *}\end{array}$ & $\begin{array}{l}-0.402 \\
(0.042)^{* * *}\end{array}$ & $\begin{array}{c}-0.405 \\
(0.038)^{* * *}\end{array}$ & $\begin{array}{c}-0.378 \\
(0.036)^{* * * *}\end{array}$ & $\begin{array}{l}-0.507 \\
(0.043)^{* * * *}\end{array}$ & $\begin{array}{l}-0.501 \\
(0.043)^{* * *}\end{array}$ & $\begin{array}{l}-0.351 \\
(0.042) * * *\end{array}$ & $\begin{array}{l}-0.362 \\
(0.043)^{* * *}\end{array}$ & $\begin{array}{c}-0.382 \\
(0.045)^{* * * *}\end{array}$ & $\begin{array}{l}-0.318 \\
(0.043)^{* * * *}\end{array}$ & $\begin{array}{l}-0.376 \\
(0.041)^{* * * *}\end{array}$ & $\begin{array}{l}-0.388 \\
(0.041)^{* * *}\end{array}$ \\
\hline \multirow{3}{*}{ 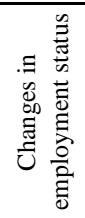 } & \multirow{3}{*}{ 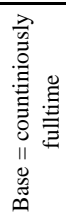 } & continuously partime & $\begin{array}{r}-0.015 \\
(0.040)\end{array}$ & $\begin{array}{c}-0.106 \\
(0.042)^{* * *}\end{array}$ & $\begin{array}{r}0.017 \\
(0.046)\end{array}$ & $\begin{array}{r}-0.057 \\
(0.047)\end{array}$ & $\begin{array}{l}0.182 \\
(0.043)^{* * *}\end{array}$ & $\begin{array}{l}0.206 \\
(0.039) * * *\end{array}$ & $\begin{array}{l}0.253 \\
(0.037)^{* * * *}\end{array}$ & $\begin{array}{l}0.218 \\
(0.043)^{* * * *}\end{array}$ & $\begin{array}{l}0.348 \\
(0.042)^{* * * *}\end{array}$ & $\begin{array}{l}0.377 \\
(0.039) * * *\end{array}$ & $\begin{array}{l}0.413 \\
(0.041)^{* * * *}\end{array}$ & $\begin{array}{l}0.461 \\
(0.043)^{* * * *}\end{array}$ & $\begin{array}{l}0.363 \\
(0.040)^{* * * *}\end{array}$ & $\begin{array}{l}0.387 \\
(0.040)^{* * * *}\end{array}$ & $\begin{array}{l}0.206 \\
(0.039) * * *\end{array}$ \\
\hline & & $\mathrm{fu}$ & $\begin{array}{l}1.103 \\
(0.042)^{* * * *}\end{array}$ & $\begin{array}{l}1.271 \\
(0.046)^{* * * *}\end{array}$ & $\begin{array}{l}1.266 \\
(0.052)^{* * * *}\end{array}$ & $\begin{array}{l}1.274 \\
(0.052)^{* * * *}\end{array}$ & $\begin{array}{l}1.474 \\
(0.051)^{* * *}\end{array}$ & $\begin{array}{l}1.455 \\
(0.045)^{* * * *}\end{array}$ & $\begin{array}{l}1.605 \\
(0.042)^{* * *}\end{array}$ & $\begin{array}{l}1.756 \\
(0.048)^{* * * *}\end{array}$ & $\begin{array}{l}1.720 \\
(0.051)^{* * * *}\end{array}$ & $\begin{array}{l}1.687 \\
(0.046) * * *\end{array}$ & $\begin{array}{l}1.662 \\
(0.047)^{* * * *}\end{array}$ & $\begin{array}{l}1.936 \\
(0.051)^{* * * *}\end{array}$ & $\begin{array}{l}1.882 \\
(0.046)^{* * * *}\end{array}$ & $\begin{array}{l}1.710 \\
(0.045)^{* * *}\end{array}$ & $\begin{array}{l}1.611 \\
(0.044) * * *\end{array}$ \\
\hline & & $\begin{array}{c}\text { from fulltime to } \\
\text { parttime }\end{array}$ & $\begin{array}{l}-1.447 \\
(0.053)^{* * * *}\end{array}$ & $\begin{array}{l}-1.619 \\
(0.055) * * *\end{array}$ & $\begin{array}{l}-1.707 \\
(0.056)^{* * *}\end{array}$ & $\begin{array}{l}-1.722 \\
(0.056)^{* * * *}\end{array}$ & $\begin{array}{l}-1.691 \\
(0.053)^{* * *}\end{array}$ & $\begin{array}{l}-1.502 \\
(0.047)^{* * *}\end{array}$ & $\begin{array}{l}-1.529 \\
(0.045) * * *\end{array}$ & $\begin{array}{l}-1.753 \\
(0.049) * * *\end{array}$ & $\begin{array}{l}-1.638 \\
(0.049) * * *\end{array}$ & $\begin{array}{l}-1.562 \\
(0.046) * * *\end{array}$ & $\begin{array}{l}-1.685 \\
(0.048)^{* * * *}\end{array}$ & $\begin{array}{l}-1.502 \\
(0.050)^{* * * *}\end{array}$ & $\begin{array}{l}-1.620 \\
(0.048)^{* * * *}\end{array}$ & $\begin{array}{l}-1.633 \\
(0.050) * * *\end{array}$ & $\begin{array}{l}-1.736 \\
(0.053)^{* * * *}\end{array}$ \\
\hline \multicolumn{3}{|c|}{ Female dummy } & $\begin{array}{r}0.020 \\
(0.024)\end{array}$ & $\begin{array}{r}0.001 \\
(0.027)\end{array}$ & $\begin{array}{r}-0.001 \\
(0.030)\end{array}$ & $\begin{array}{r}0.015 \\
(0.032)\end{array}$ & $\begin{array}{l}-0.061 \\
(0.031)^{* * *}\end{array}$ & $\begin{array}{l}-0.088 \\
(0.028)^{* * * *}\end{array}$ & $\begin{array}{l}-0.125 \\
(0.026) * * *\end{array}$ & $\begin{array}{r}-0.047 \\
(0.031)\end{array}$ & $\begin{array}{r}-0.050 \\
(0.033)\end{array}$ & $\begin{array}{l}-0.151 \\
(0.030) * * *\end{array}$ & $\begin{array}{l}-0.150 \\
(0.031)^{* * * *}\end{array}$ & $\begin{array}{l}-0.148 \\
(0.033)^{* * * *}\end{array}$ & $\begin{array}{r}-0.029 \\
(0.032)\end{array}$ & $\begin{array}{l}-0.100 \\
(0.031)^{* * *}\end{array}$ & $\begin{array}{l}-0.101 \\
(0.030)^{* * * *}\end{array}$ \\
\hline \multirow{3}{*}{ 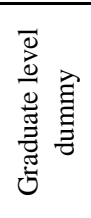 } & \multirow{3}{*}{ 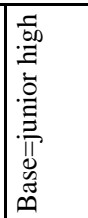 } & High school & $\begin{array}{l}-0.168 \\
(0.027)^{* * * *}\end{array}$ & $\begin{array}{l}-0.095 \\
(0.031)^{* * *}\end{array}$ & $\begin{array}{l}-0.159 \\
(0.036)^{* * *}\end{array}$ & $\begin{array}{l}-0.101 \\
(0.038)^{* * * *}\end{array}$ & $\begin{array}{l}-0.116 \\
(0.039)^{* * *}\end{array}$ & $\begin{array}{r}-0.053 \\
(0.038)\end{array}$ & $\begin{array}{l}-0.120 \\
(0.036) * * *\end{array}$ & $\begin{array}{l}-0.135 \\
(0.046) * * *\end{array}$ & $\begin{array}{r}0.011 \\
(0.049)\end{array}$ & $\begin{array}{r}-0.026 \\
(0.050)\end{array}$ & $\begin{array}{r}-0.078 \\
(0.053)\end{array}$ & $\begin{array}{r}-0.006 \\
(0.061)\end{array}$ & $\begin{array}{l}-0.190 \\
(0.058) * * *\end{array}$ & $\begin{array}{l}-0.134 \\
(0.057)^{* * *}\end{array}$ & $\begin{array}{l}-0.118 \\
(0.053)^{* *}\end{array}$ \\
\hline & & $\mathrm{J}$ & $\begin{array}{l}-0.385 \\
(0.044)^{* * * *}\end{array}$ & $\begin{array}{l}-0.362 \\
(0.048)^{* * *}\end{array}$ & $\begin{array}{l}-0.349 \\
(0.054)^{* * *}\end{array}$ & $\begin{array}{l}-0.341 \\
(0.057)^{* * *}\end{array}$ & $\begin{array}{l}-0.386 \\
(0.054)^{* * *}\end{array}$ & $\begin{array}{l}-0.226 \\
(0.046)^{* * * *}\end{array}$ & $\begin{array}{l}-0.285 \\
(0.044) * * *\end{array}$ & $\begin{array}{l}-0.332 \\
(0.055) * * *\end{array}$ & $\begin{array}{l}-0.207 \\
(0.058)^{* * * *}\end{array}$ & $\begin{array}{l}-0.203 \\
(0.057) * * *\end{array}$ & $\begin{array}{l}-0.303 \\
(0.060)^{* * *}\end{array}$ & $\begin{array}{r}-0.117 \\
(0.067)^{*}\end{array}$ & $\begin{array}{l}-0.314 \\
(0.064)^{* * * *}\end{array}$ & $\begin{array}{l}-0.260 \\
(0.063) * * *\end{array}$ & $\begin{array}{l}-0.281 \\
(0.059)^{* * * *}\end{array}$ \\
\hline & & University & $\begin{array}{l}-0.173 \\
(0.043)^{* * * *}\end{array}$ & $\begin{array}{l}-0.282 \\
(0.048)^{* * * *}\end{array}$ & $\begin{array}{l}-0.294 \\
(0.055)^{* * *}\end{array}$ & $\begin{array}{l}-0.244 \\
(0.059)^{* * * *}\end{array}$ & $\begin{array}{l}-0.281 \\
(0.057)^{* * *}\end{array}$ & $\begin{array}{r}-0.042 \\
(0.052)\end{array}$ & $\begin{array}{c}-0.089 \\
(0.049)^{*}\end{array}$ & $\begin{array}{l}-0.176 \\
(0.060)^{* * *}\end{array}$ & $\begin{array}{r}-0.091 \\
(0.063)\end{array}$ & $\begin{array}{r}0.009 \\
(0.061)\end{array}$ & $\begin{array}{l}-0.181 \\
(0.063)^{* * * *}\end{array}$ & $\begin{array}{r}0.090 \\
(0.070)\end{array}$ & $\begin{array}{l}-0.181 \\
(0.067)^{* * * *}\end{array}$ & $\begin{array}{l}-0.177 \\
(0.065) * * *\end{array}$ & $\begin{array}{l}-0.158 \\
(0.061)^{* * * *}\end{array}$ \\
\hline \multirow{4}{*}{ 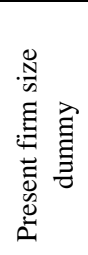 } & \multirow{4}{*}{$\begin{array}{l}\text { Dి } \\
1 \\
1 \\
11 \\
\check{D} \\
\ddot{D} \\
\oplus\end{array}$} & $30-99$ & $\begin{array}{l}-0.251 \\
(0.044)^{* * * *}\end{array}$ & $\begin{array}{l}-0.264 \\
(0.046)^{* * *}\end{array}$ & $\begin{array}{l}-0.212 \\
(0.051)^{* * *}\end{array}$ & $\begin{array}{l}-0.118 \\
(0.051)^{* * *}\end{array}$ & $\begin{array}{l}-0.330 \\
(0.051)^{* * *}\end{array}$ & $\begin{array}{c}-0.115 \\
(0.049)^{* * *}\end{array}$ & $\begin{array}{c}-0.153 \\
(0.048)^{* * * *}\end{array}$ & $\begin{array}{c}-0.145 \\
(0.057)^{* * *}\end{array}$ & $\begin{array}{l}-0.230 \\
(0.056)^{* * * *}\end{array}$ & $\begin{array}{l}-0.224 \\
(0.056) * * *\end{array}$ & $\begin{array}{l}-0.194 \\
(0.058)^{* * * *}\end{array}$ & $\begin{array}{l}-0.208 \\
(0.064)^{* * * *}\end{array}$ & $\begin{array}{c}-0.153 \\
(0.065)^{* * *}\end{array}$ & $\begin{array}{l}-0.277 \\
(0.066) * * *\end{array}$ & $\begin{array}{c}-0.243 \\
(0.067)^{* * * *}\end{array}$ \\
\hline & & 9 & $\begin{array}{l}-0.470 \\
(0.045)^{* * *}\end{array}$ & $\begin{array}{l}-0.496 \\
(0.047)^{* * * *}\end{array}$ & $\begin{array}{l}-0.434 \\
(0.053)^{* * * *}\end{array}$ & $\begin{array}{c}-0.345 \\
(0.053)^{* * * *}\end{array}$ & $\begin{array}{c}-0.438 \\
(0.053)^{* * *}\end{array}$ & $\begin{array}{l}-0.311 \\
(0.051)^{* * * *}\end{array}$ & $\begin{array}{l}-0.316 \\
(0.049)^{* * * *}\end{array}$ & $\begin{array}{c}-0.281 \\
(0.059)^{* * * *}\end{array}$ & $\begin{array}{l}-0.507 \\
(0.058)^{* * * *}\end{array}$ & $\begin{array}{l}-0.380 \\
(0.057)^{* * * *}\end{array}$ & $\begin{array}{c}-0.469 \\
(0.058)^{* * *}\end{array}$ & $\begin{array}{l}-0.247 \\
(0.064)^{* * * *}\end{array}$ & $\begin{array}{c}-0.165 \\
(0.066)^{* * *}\end{array}$ & $\begin{array}{c}-0.330 \\
(0.065)^{* * * *}\end{array}$ & $\begin{array}{c}-0.204 \\
(0.064)^{* * * *}\end{array}$ \\
\hline & & 3 & $\begin{array}{l}-0.484 \\
(0.046)^{* * * *}\end{array}$ & $\begin{array}{l}-0.537 \\
(0.049)^{* * * *}\end{array}$ & $\begin{array}{l}-0.409 \\
(0.055)^{* * * *}\end{array}$ & $\begin{array}{l}-0.276 \\
(0.057)^{* * * *}\end{array}$ & $\begin{array}{c}-0.443 \\
(0.056)^{* * *}\end{array}$ & $\begin{array}{l}-0.329 \\
(0.053)^{* * * *}\end{array}$ & $\begin{array}{l}-0.208 \\
(0.051)^{* * * *}\end{array}$ & $\begin{array}{c}-0.263 \\
(0.061)^{* * * *}\end{array}$ & $\begin{array}{l}-0.324 \\
(0.060)^{* * * *}\end{array}$ & $\begin{array}{l}-0.258 \\
(0.059) * * * *\end{array}$ & $\begin{array}{l}-0.423 \\
(0.060)^{* * * *}\end{array}$ & $\begin{array}{l}-0.387 \\
(0.067)^{* * * *}\end{array}$ & $\begin{array}{l}-0.215 \\
(0.068)^{* * * *}\end{array}$ & $\begin{array}{l}-0.281 \\
(0.066) * * *\end{array}$ & $\begin{array}{l}-0.191 \\
(0.067)^{* * *}\end{array}$ \\
\hline & & סוז & -0.307 & -0.392 & -0.277 & -0.203 & -0.334 & -0.279 & -0.212 & -0.269 & -0.411 & -0.310 & -0.369 & -0.346 & -0.151 & -0.224 & -0.178 \\
\hline
\end{tabular}




\begin{tabular}{|c|c|c|c|c|c|c|c|c|c|c|c|c|c|c|c|c|c|}
\hline & & urei & $(0.047)^{* * *}$ & $(0.050)^{* * * *}$ & $(0.057)^{* * *}$ & $(0.058)^{* * *}$ & $(0.056)^{* * *}$ & $(0.054)^{* * * *}$ & $(0.051)^{* * *}$ & $(0.062)^{* * * *}$ & $(0.061)^{* * * *}$ & $(0.060) * * *$ & $(0.060) * * *$ & $(0.068)^{* * * *}$ & $(0.068)^{* * *}$ & $(0.067)^{* * * *}$ & $.067)^{* * * *}$ \\
\hline \multirow{8}{*}{ 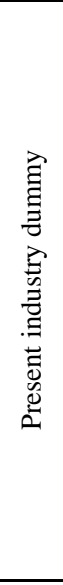 } & \multirow{8}{*}{ 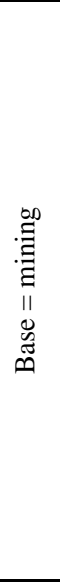 } & Construction & $\begin{array}{c}-0.164 \\
(0.094)^{*}\end{array}$ & $\begin{array}{c}-0.163 \\
(0.098)^{*}\end{array}$ & $\begin{array}{l}-0.513 \\
(0.123)^{* * *}\end{array}$ & $\begin{array}{l}0.329 \\
(0.128)^{* * *}\end{array}$ & $\begin{array}{r}0.033 \\
(0.117)\end{array}$ & $\begin{array}{r}0.014 \\
(0.126)\end{array}$ & $\begin{array}{r}0.149 \\
(0.123)\end{array}$ & $\begin{array}{c}-0.237 \\
(0.127)^{*}\end{array}$ & $\begin{array}{l}-0.471 \\
(0.152)^{* * *}\end{array}$ & $\begin{array}{l}-0.344 \\
(0.153)^{* * *}\end{array}$ & $\begin{array}{r}-0.226 \\
(0.169)\end{array}$ & $\begin{array}{r}-0.189 \\
(0.198)\end{array}$ & $\begin{array}{r}0.174 \\
(0.182)\end{array}$ & $\begin{array}{r}-0.189 \\
(0.258)\end{array}$ & $\begin{array}{r}-0.083 \\
(0.232)\end{array}$ \\
\hline & & Manu & $\begin{array}{l}-0.399 \\
(0.085)^{* * *}\end{array}$ & $\begin{array}{l}-0.401 \\
(0.087)^{* * *}\end{array}$ & $\begin{array}{l}-0.723 \\
(0.110)^{* * *}\end{array}$ & $\begin{array}{r}0.018 \\
(0.115)\end{array}$ & $\begin{array}{r}-0.168 \\
(0.106)\end{array}$ & $\begin{array}{r}-0.180 \\
(0.116)\end{array}$ & $\begin{array}{r}-0.017 \\
(0.115)\end{array}$ & $\begin{array}{l}-0.365 \\
(0.115)^{* * *}\end{array}$ & $\begin{array}{l}-0.490 \\
(0.142)^{* * *}\end{array}$ & $\begin{array}{l}-0.422 \\
(0.141)^{* * * *}\end{array}$ & $\begin{array}{l}-0.370 \\
(0.157)^{* *}\end{array}$ & $\begin{array}{r}-0.200 \\
(0.185)\end{array}$ & $\begin{array}{r}0.032 \\
(0.168)\end{array}$ & $\begin{array}{r}0.087 \\
(0.245)\end{array}$ & $\begin{array}{r}0.176 \\
(0.217)\end{array}$ \\
\hline & & Electr & $\begin{array}{c}-0.630 \\
(0.151)^{* * * *}\end{array}$ & $\begin{array}{c}-0.550 \\
(0.158)^{* * * *}\end{array}$ & $\begin{array}{c}-1.001 \\
(0.191)^{* * * *}\end{array}$ & $\begin{array}{r}-0.099 \\
(0.204)\end{array}$ & $\begin{array}{c}-0.350 \\
(0.181)^{*}\end{array}$ & $\begin{array}{r}-0.315 \\
(0.190)^{*}\end{array}$ & $\begin{array}{c}-0.462 \\
(0.204)^{* *}\end{array}$ & $\begin{array}{c}-0.532 \\
(0.222 * *\end{array}$ & $\begin{array}{c}-0.799 \\
(0.266)^{* * * *}\end{array}$ & $\begin{array}{c}-0.914 \\
(0.280)^{* * * *}\end{array}$ & $\begin{array}{c}-0.542 \\
(0.271)^{* * *}\end{array}$ & $\begin{array}{r}-0.316 \\
(0.281)\end{array}$ & $\begin{array}{c}-0.581 \\
(0.237)^{* * *}\end{array}$ & $\begin{array}{c}-0.920 \\
(0.335) * * *\end{array}$ & $\begin{array}{r}-0.005 \\
(0.307)\end{array}$ \\
\hline & & $\begin{array}{r}\text { Comm } \\
\text { trans }\end{array}$ & $\begin{array}{r}-0.053 \\
(0.102)\end{array}$ & $\begin{array}{r}-0.030 \\
(0.105)\end{array}$ & $\begin{array}{l}-0.569 \\
(0.123)^{* * *}\end{array}$ & $\begin{array}{l}0.323 \\
(0.131)^{* *}\end{array}$ & $\begin{array}{r}-0.077 \\
(0.121)\end{array}$ & $\begin{array}{r}-0.178 \\
(0.127)\end{array}$ & $\begin{array}{r}-0.004 \\
(0.126)\end{array}$ & $\begin{array}{r}-0.099 \\
(0.130)\end{array}$ & $\begin{array}{l}-0.458 \\
(0.156)^{* * * *}\end{array}$ & $\begin{array}{l}-0.490 \\
(0.153)^{* * * *}\end{array}$ & $\begin{array}{l}-0.448 \\
(0.170)^{* * * *}\end{array}$ & $\begin{array}{r}-0.197 \\
(0.203)\end{array}$ & $\begin{array}{r}-0.162 \\
(0.183)\end{array}$ & $\begin{array}{r}-0.043 \\
(0.249)\end{array}$ & $\begin{array}{r}-0.006 \\
(0.222)\end{array}$ \\
\hline & & $\begin{array}{c}\text { Wholesale/ retail/ } \\
\text { restaurants }\end{array}$ & $\begin{array}{l}-0.523 \\
(0.098)^{* * *}\end{array}$ & $\begin{array}{l}-0.453 \\
(0.101)^{* * *}\end{array}$ & $\begin{array}{l}-0.943 \\
(0.125)^{* * *}\end{array}$ & $\begin{array}{r}-0.005 \\
(0.133)\end{array}$ & $\begin{array}{l}-0.337 \\
(0.122) * * *\end{array}$ & $\begin{array}{l}-0.484 \\
(0.127)^{* * *}\end{array}$ & $\begin{array}{l}-0.304 \\
(0.126)^{* *}\end{array}$ & $\begin{array}{l}-0.552 \\
(0.127)^{* * *}\end{array}$ & $\begin{array}{l}-0.800 \\
(0.151)^{* * * *}\end{array}$ & $\begin{array}{l}-0.669 \\
(0.149)^{* * * *}\end{array}$ & $\begin{array}{l}-0.839 \\
(0.165)^{* * * *}\end{array}$ & $\begin{array}{c}-0.320 \\
(0.193)^{*}\end{array}$ & $\begin{array}{l}-0.394 \\
(0.175)^{* * *}\end{array}$ & $\begin{array}{r}-0.294 \\
(0.249)\end{array}$ & $\begin{array}{r}-0.030 \\
(0.220)\end{array}$ \\
\hline & & Finance/ & $\begin{array}{l}-0.716 \\
(0.112)^{* * *}\end{array}$ & $\begin{array}{l}-0.585 \\
(0.125)^{* * *}\end{array}$ & $\begin{array}{l}-0.628 \\
(0.146)^{* * *}\end{array}$ & $\begin{array}{r}-0.062 \\
(0.147)\end{array}$ & $\begin{array}{l}-0.410 \\
(0.141)^{* * *}\end{array}$ & $\begin{array}{r}-0.023 \\
(0.141)\end{array}$ & $\begin{array}{r}-0.191 \\
(0.142)\end{array}$ & $\begin{array}{l}-0.312 \\
(0.137)^{* *}\end{array}$ & $\begin{array}{l}-0.430 \\
(0.164)^{* * *}\end{array}$ & $\begin{array}{r}-0.288 \\
(0.162)^{*}\end{array}$ & $\begin{array}{l}-0.459 \\
(0.176)^{* * *}\end{array}$ & $\begin{array}{r}-0.067 \\
(0.206)\end{array}$ & $\begin{array}{r}-0.024 \\
(0.189)\end{array}$ & $\begin{array}{r}-0.063 \\
(0.259)\end{array}$ & $\begin{array}{r}0.114 \\
(0.231)\end{array}$ \\
\hline & & Real $\mathrm{C}$ & $\begin{array}{l}-0.445 \\
(0.110)^{* * *}\end{array}$ & $\begin{array}{r}-0.150 \\
(0.131)\end{array}$ & $\begin{array}{l}-0.745 \\
(0.140)^{* * *}\end{array}$ & $\begin{array}{r}0.097 \\
(0.151)\end{array}$ & $\begin{array}{c}-0.421 \\
(0.141)^{* * * *}\end{array}$ & $\begin{array}{l}-0.432 \\
(0.140)^{* * * *}\end{array}$ & $\begin{array}{l}-0.403 \\
(0.141)^{* * * *}\end{array}$ & $\begin{array}{c}-0.505 \\
(0.143)^{* * * *}\end{array}$ & $\begin{array}{l}-0.593 \\
(0.168)^{* * *}\end{array}$ & $\begin{array}{r}-0.289 \\
(0.159)^{*}\end{array}$ & $\begin{array}{c}-0.731 \\
(0.177)^{* * *}\end{array}$ & $\begin{array}{r}-0.236 \\
(0.217)\end{array}$ & $\begin{array}{r}-0.152 \\
(0.208)\end{array}$ & $\begin{array}{r}-0.276 \\
(0.266)\end{array}$ & $\begin{array}{c}0.403 \\
(0.237)^{*}\end{array}$ \\
\hline & & Servi & $\begin{array}{c}-0.506 \\
(0.087)^{* * * *}\end{array}$ & $\begin{array}{c}-0.469 \\
(0.089)^{* * * *}\end{array}$ & $\begin{array}{c}-0.693 \\
(0.112)^{* * * *}\end{array}$ & $\begin{array}{r}0.011 \\
(0.118) \\
\end{array}$ & $\begin{array}{c}-0.220 \\
(0.109)^{* * *}\end{array}$ & $\begin{array}{c}-0.309 \\
(0.118)^{* * * *}\end{array}$ & $\begin{array}{c}-0.265 \\
(0.118)^{* * *} \\
\end{array}$ & $\begin{array}{c}-0.525 \\
(0.118)^{* * * *}\end{array}$ & $\begin{array}{c}-0.651 \\
(0.144)^{* * * *}\end{array}$ & $\begin{array}{l}-0.597 \\
(0.142)^{* * * *}\end{array}$ & $\begin{array}{c}-0.522 \\
(0.158)^{* * * *}\end{array}$ & $\begin{array}{c}-0.346 \\
(0.187)^{*} \\
\end{array}$ & $\begin{array}{r}-0.266 \\
(0.169) \\
\end{array}$ & $\begin{array}{r}-0.125 \\
(0.246) \\
\end{array}$ & $\begin{array}{r}0.042 \\
(0.218) \\
\end{array}$ \\
\hline \multirow{7}{*}{ 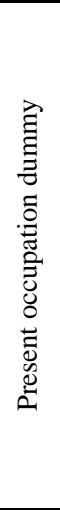 } & \multirow{7}{*}{ 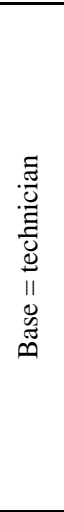 } & Mana & $\begin{array}{c}-0.160 \\
(0.070)^{* * *}\end{array}$ & $\begin{array}{c}-0.169 \\
(0.085)^{* * *}\end{array}$ & $\begin{array}{c}0.027 \\
(0.090)\end{array}$ & $\begin{array}{c}-0.214 \\
(0.095)^{* * *}\end{array}$ & $\begin{array}{c}-0.251 \\
(0.098)^{* * *}\end{array}$ & $\begin{array}{c}-0.151 \\
(0.087)^{*}\end{array}$ & $\begin{array}{r}-0.145 \\
(0.081)^{*}\end{array}$ & $\begin{array}{c}-0.288 \\
(0.092)^{* * * *}\end{array}$ & $\begin{array}{r}0.033 \\
(0.095)\end{array}$ & $\begin{array}{r}-0.091 \\
(0.084)\end{array}$ & $\begin{array}{c}-0.197 \\
(0.082)^{* *}\end{array}$ & $\begin{array}{c}-0.191 \\
(0.086)^{* * *}\end{array}$ & $\begin{array}{c}-0.238 \\
(0.084)^{* * *}\end{array}$ & $\begin{array}{r}-0.080 \\
(0.080)\end{array}$ & $\begin{array}{c}-0.182 \\
(0.077)^{* * *}\end{array}$ \\
\hline & & Admir & $\begin{array}{c}-0.370 \\
(0.040)^{* * * *}\end{array}$ & $\begin{array}{c}-0.362 \\
(0.044)^{* * *}\end{array}$ & $\begin{array}{l}-0.320 \\
(0.050)^{* * * *}\end{array}$ & $\begin{array}{l}-0.406 \\
(0.055)^{* * * *}\end{array}$ & $\begin{array}{c}-0.483 \\
(0.053)^{* * * *}\end{array}$ & $\begin{array}{c}-0.392 \\
(0.046)^{* * * *}\end{array}$ & $\begin{array}{l}-0.456 \\
(0.041)^{* * * *}\end{array}$ & $\begin{array}{c}-0.565 \\
(0.048)^{* * * *}\end{array}$ & $\begin{array}{l}-0.388 \\
(0.051)^{* * * *}\end{array}$ & $\begin{array}{l}-0.294 \\
(0.047)^{* * * *}\end{array}$ & $\begin{array}{c}-0.287 \\
(0.046)^{* * *}\end{array}$ & $\begin{array}{c}-0.385 \\
(0.048)^{* * * *}\end{array}$ & $\begin{array}{c}-0.445 \\
(0.047)^{* * * *}\end{array}$ & $\begin{array}{l}-0.265 \\
(0.045)^{* * * *}\end{array}$ & $\begin{array}{l}-0.248 \\
(0.044)^{* * * *}\end{array}$ \\
\hline & & les & $\begin{array}{c}-0.131 \\
(0.055)^{* * *}\end{array}$ & $\begin{array}{c}-0.135 \\
(0.058)^{* * *}\end{array}$ & $\begin{array}{r}0.001 \\
(0.066)\end{array}$ & $\begin{array}{c}-0.133 \\
(0.070)^{*}\end{array}$ & $\begin{array}{c}-0.195 \\
(0.067) * * * *\end{array}$ & $\begin{array}{l}-0.160 \\
(0.058)^{* * * *}\end{array}$ & $\begin{array}{l}-0.214 \\
(0.056)^{* * * *}\end{array}$ & $\begin{array}{l}-0.270 \\
(0.062)^{* * * *}\end{array}$ & $\begin{array}{r}-0.095 \\
(0.065)\end{array}$ & $\begin{array}{l}-0.170 \\
(0.058)^{* * * *}\end{array}$ & $\begin{array}{c}-0.133 \\
(0.060)^{* * *}\end{array}$ & $\begin{array}{l}-0.276 \\
(0.064)^{* * * *}\end{array}$ & $\begin{array}{l}-0.190 \\
(0.060)^{* * * *}\end{array}$ & $\begin{array}{l}-0.227 \\
(0.058) * * *\end{array}$ & $\begin{array}{l}-0.180 \\
(0.056)^{* * * *}\end{array}$ \\
\hline & & Service & $\begin{array}{l}0.231 \\
(0.071)^{* * *}\end{array}$ & $\begin{array}{r}0.050 \\
(0.048)\end{array}$ & $\begin{array}{l}0.108 \\
(0.052)^{* *}\end{array}$ & $\begin{array}{r}0.040 \\
(0.055)\end{array}$ & $\begin{array}{l}-0.174 \\
(0.053) * * *\end{array}$ & $\begin{array}{c}-0.110 \\
(0.048)^{* * *}\end{array}$ & $\begin{array}{l}-0.140 \\
(0.046) * * * *\end{array}$ & $\begin{array}{c}-0.146 \\
(0.051)^{* * * *}\end{array}$ & $\begin{array}{r}-0.011 \\
(0.054)\end{array}$ & $\begin{array}{r}-0.090 \\
(0.051)^{*}\end{array}$ & $\begin{array}{c}-0.107 \\
(0.050)^{* *}\end{array}$ & $\begin{array}{l}-0.133 \\
(0.051)^{* * *}\end{array}$ & $\begin{array}{l}-0.167 \\
(0.050)^{* * * *}\end{array}$ & $\begin{array}{r}-0.048 \\
(0.052)\end{array}$ & $\begin{array}{l}-0.232 \\
(0.052)^{* * * *}\end{array}$ \\
\hline & & $\begin{array}{r}\text { Comm } \\
\text { transp }\end{array}$ & $\begin{array}{r}-0.006 \\
(0.088)\end{array}$ & $\begin{array}{l}0.286 \\
(0.075)^{* * *}\end{array}$ & $\begin{array}{l}0.226 \\
(0.081)^{* * * *}\end{array}$ & $\begin{array}{l}0.315 \\
(0.087)^{* * * *}\end{array}$ & $\begin{array}{l}0.394 \\
(0.084)^{* * * *}\end{array}$ & $\begin{array}{l}0.382 \\
(0.076)^{* * * *}\end{array}$ & $\begin{array}{l}0.184 \\
(0.073)^{* *}\end{array}$ & $\begin{array}{r}-0.073 \\
(0.087)\end{array}$ & $\begin{array}{l}0.230 \\
(0.095)^{* * *}\end{array}$ & $\begin{array}{l}0.245 \\
(0.090)^{* * * *}\end{array}$ & $\begin{array}{l}0.221 \\
(0.093)^{* * *}\end{array}$ & $\begin{array}{l}0.214 \\
(0.105)^{* * *}\end{array}$ & $\begin{array}{l}0.234 \\
(0.096)^{* * *}\end{array}$ & $\begin{array}{r}-0.009 \\
(0.080)\end{array}$ & $\begin{array}{r}-0.005 \\
(0.082)\end{array}$ \\
\hline & & Prod & $\begin{array}{l}0.305 \\
(0.046)^{* * * *}\end{array}$ & $\begin{array}{r}0.029 \\
(0.043)\end{array}$ & $\begin{array}{r}0.069 \\
(0.050)\end{array}$ & $\begin{array}{r}0.034 \\
(0.054)\end{array}$ & $\begin{array}{c}-0.124 \\
(0.051)^{* *}\end{array}$ & $\begin{array}{r}-0.015 \\
(0.046)\end{array}$ & $\begin{array}{c}-0.080 \\
(0.041)^{* *}\end{array}$ & $\begin{array}{c}-0.123 \\
(0.049)^{* * *}\end{array}$ & $\begin{array}{r}-0.067 \\
(0.051)\end{array}$ & $\begin{array}{r}0.031 \\
(0.046)\end{array}$ & $\begin{array}{c}-0.137 \\
(0.046)^{* * *}\end{array}$ & $\begin{array}{r}-0.061 \\
(0.050)\end{array}$ & $\begin{array}{r}-0.040 \\
(0.047)\end{array}$ & $\begin{array}{r}-0.048 \\
(0.044)\end{array}$ & $\begin{array}{r}0.011 \\
(0.042)\end{array}$ \\
\hline & & ners & $\begin{array}{l}0.107 \\
(0.038)^{* * *}\end{array}$ & $\begin{array}{c}-0.139 \\
(0.055)^{* * *} \\
\end{array}$ & $\begin{array}{r}-0.046 \\
(0.060) \\
\end{array}$ & $\begin{array}{r}0.072 \\
(0.063) \\
\end{array}$ & $\begin{array}{c}-0.187 \\
(0.063) * * * \\
\end{array}$ & $\begin{array}{c}-0.116 \\
(0.059)^{* * *}\end{array}$ & $\begin{array}{c}-0.144 \\
(0.056)^{* * *}\end{array}$ & $\begin{array}{c}-0.233 \\
(0.067)^{* * *}\end{array}$ & $\begin{array}{r}-0.142 \\
(0.081)^{*}\end{array}$ & $\begin{array}{r}0.005 \\
(0.076)\end{array}$ & $\begin{array}{l}-0.252 \\
(0.075)^{* * *}\end{array}$ & $\begin{array}{c}-0.197 \\
(0.079)^{* *}\end{array}$ & $\begin{array}{c}-0.365 \\
(0.075)^{* * *}\end{array}$ & $\begin{array}{c}-0.358 \\
(0.097)^{* * * *}\end{array}$ & $\begin{array}{c}-0.352 \\
(0.107)^{* * * *}\end{array}$ \\
\hline \multirow{4}{*}{ 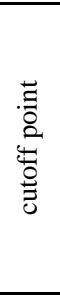 } & & $\mathrm{TAU}_{30}$ & $\begin{array}{l}-3.445 \\
(0.144)^{* * * *}\end{array}$ & $\begin{array}{l}-4.305 \\
(0.159)^{* * * *}\end{array}$ & $\begin{array}{l}-4.196 \\
(0.185)^{* * * *}\end{array}$ & $\begin{array}{c}-3.484 \\
(0.193)^{* * * *}\end{array}$ & $\begin{array}{c}-4.023 \\
(0.188) * * *\end{array}$ & $\begin{array}{c}-4.215 \\
(0.184)^{* * * *}\end{array}$ & $\begin{array}{c}-3.958 \\
(0.178)^{* * * *}\end{array}$ & $\begin{array}{l}-4.750 \\
(0.200)^{* * * *}\end{array}$ & $\begin{array}{c}-4.815 \\
(0.224)^{* * * *}\end{array}$ & $\begin{array}{c}-4.415 \\
(0.216)^{* * *}\end{array}$ & $\begin{array}{c}-4.454 \\
(0.235)^{* * *}\end{array}$ & $\begin{array}{c}-4.352 \\
(0.262)^{* * * *}\end{array}$ & $\begin{array}{c}-3.408 \\
(0.246)^{* * * *}\end{array}$ & $\begin{array}{c}-4.199 \\
(0.302) * * *\end{array}$ & $\begin{array}{l}-3.731 \\
(0.276)^{* * *}\end{array}$ \\
\hline & & $\mathrm{TAU}_{15}$ & $\begin{array}{c}-1.986 \\
(0.142)^{* * * *}\end{array}$ & $\begin{array}{l}-2.712 \\
(0.157)^{* * * *}\end{array}$ & $\begin{array}{l}-2.713 \\
(0.183)^{* * * *}\end{array}$ & $\begin{array}{l}-1.953 \\
(0.191)^{* * * *}\end{array}$ & $\begin{array}{l}-2.529 \\
(0.186) * * *\end{array}$ & $\begin{array}{l}-2.739 \\
(0.182)^{* * * *}\end{array}$ & $\begin{array}{l}-2.439 \\
(0.176)^{* * * *}\end{array}$ & $\begin{array}{c}-3.543 \\
(0.199)^{* * * *}\end{array}$ & $\begin{array}{l}-3.598 \\
(0.222)^{* * * *}\end{array}$ & $\begin{array}{l}-3.247 \\
(0.215)^{* * * *}\end{array}$ & $\begin{array}{c}-3.230 \\
(0.233)^{* * * *}\end{array}$ & $\begin{array}{l}-3.132 \\
(0.261)^{* * * *}\end{array}$ & $\begin{array}{l}-2.253 \\
(0.245)^{* * * *}\end{array}$ & $\begin{array}{l}-2.933 \\
(0.301)^{* * * *}\end{array}$ & $\begin{array}{l}-2.477 \\
(0.275)^{* * * *}\end{array}$ \\
\hline & & $\mathrm{TAU}_{0}$ & $\begin{array}{c}0.270 \\
(0.142)^{*}\end{array}$ & $\begin{array}{c}-0.491 \\
(0.156)^{* * * *}\end{array}$ & $\begin{array}{c}-0.583 \\
(0.182)^{* * * *}\end{array}$ & $\begin{array}{r}0.224 \\
(0.191)\end{array}$ & $\begin{array}{r}-0.256 \\
(0.186)\end{array}$ & $\begin{array}{c}-0.529 \\
(0.182)^{* * *}\end{array}$ & $\begin{array}{r}-0.178 \\
(0.176)\end{array}$ & $\begin{array}{r}-0.276 \\
(0.197)\end{array}$ & $\begin{array}{c}-0.467 \\
(0.221)^{* *}\end{array}$ & $\begin{array}{r}-0.154 \\
(0.214)\end{array}$ & $\begin{array}{r}-0.063 \\
(0.232)\end{array}$ & $\begin{array}{r}-0.022 \\
(0.260)\end{array}$ & $\begin{array}{l}0.897 \\
(0.245)^{* * *}\end{array}$ & $\begin{array}{r}0.041 \\
(0.301)\end{array}$ & $\begin{array}{c}0.521 \\
(0.274)^{*}\end{array}$ \\
\hline & & TAU $_{-15}$ & $\begin{array}{l}2.664 \\
(0.143)^{* * * *}\end{array}$ & $\begin{array}{l}1.887 \\
(0.157)^{* * *}\end{array}$ & $\begin{array}{l}1.696 \\
(0.183) * * *\end{array}$ & $\begin{array}{l}2.405 \\
(0.193)^{* * * *}\end{array}$ & $\begin{array}{l}1.899 \\
(0.187)^{* * * *}\end{array}$ & $\begin{array}{l}1.621 \\
(0.183)^{* * * *}\end{array}$ & $\begin{array}{l}2.056 \\
(0.177)^{* * * *}\end{array}$ & $\begin{array}{l}1.354 \\
(0.198)^{* * * *}\end{array}$ & $\begin{array}{l}1.149 \\
(0.222)^{* * * *}\end{array}$ & $\begin{array}{l}1.508 \\
(0.215)^{* * * *}\end{array}$ & $\begin{array}{l}1.608 \\
(0.233)^{* * *}\end{array}$ & $\begin{array}{l}1.566 \\
(0.261)^{* * * *}\end{array}$ & $\begin{array}{l}2.516 \\
(0.246)^{* * * *}\end{array}$ & $\begin{array}{l}1.656 \\
(0.301)^{* * * *}\end{array}$ & $\begin{array}{l}2.146 \\
(0.275)^{* * * *}\end{array}$ \\
\hline \multicolumn{3}{|c|}{ Observations } & 38614 & 31167 & 23763 & 21279 & 23321 & 28218 & 32418 & 26306 & 23151 & 26711 & 25591 & 21960 & 24675 & 25917 & 27556 \\
\hline
\end{tabular}

Standard errors in parentheses

*** $\mathrm{p}<0.01,{ }^{* *} \mathrm{p}<0.05,{ }^{*} \mathrm{p}<0.1$ 
Appendix 2c: Results of Ordered Logit (Shukko Assignment Sample)

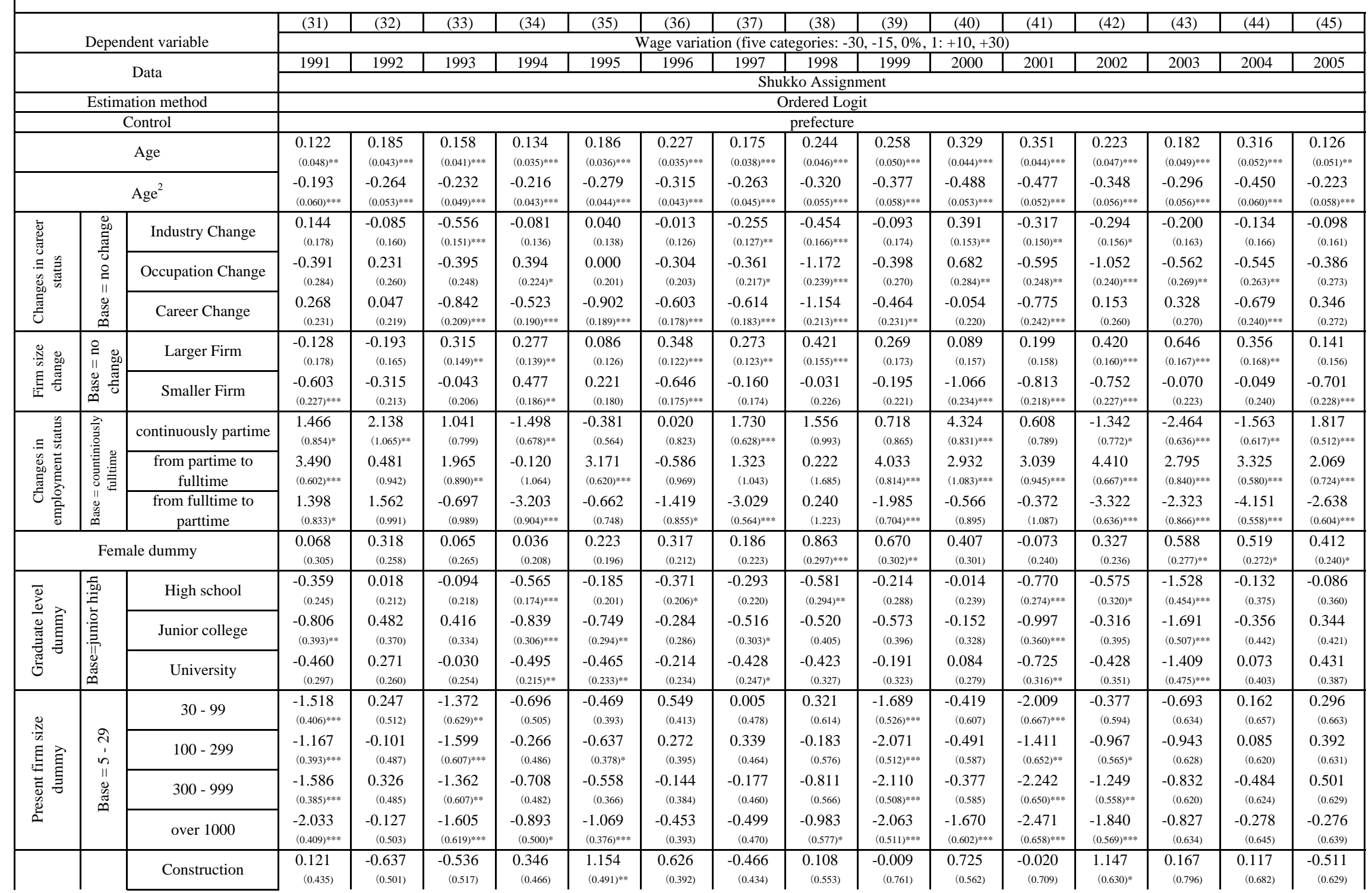




\begin{tabular}{|c|c|c|c|c|c|c|c|c|c|c|c|c|c|c|c|c|c|}
\hline \multirow{7}{*}{ 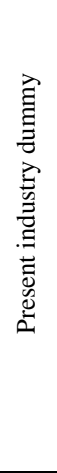 } & \multirow{7}{*}{ 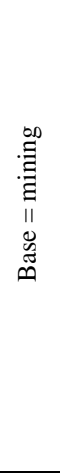 } & Manufacturing & $\begin{array}{r}-0.371 \\
(0.287)\end{array}$ & $\begin{array}{r}-0.311 \\
(0.326)\end{array}$ & $\begin{array}{l}-1.525 \\
(0.433)^{* * * *}\end{array}$ & $\begin{array}{r}0.076 \\
(0.399)\end{array}$ & $\begin{array}{r}0.349 \\
(0.436)\end{array}$ & $\begin{array}{l}1.036 \\
(0.344)^{* * * *}\end{array}$ & $\begin{array}{r}-0.443 \\
(0.397)\end{array}$ & $\begin{array}{c}0.611 \\
(0.502)\end{array}$ & $\begin{array}{r}0.395 \\
(0.731)\end{array}$ & $\begin{array}{l}1.010 \\
(0.529)^{*}\end{array}$ & $\begin{array}{r}0.237 \\
(0.683)\end{array}$ & $\begin{array}{l}2.312 \\
(0.596)^{* * * *}\end{array}$ & $\begin{array}{r}0.640 \\
(0.745)\end{array}$ & $\begin{array}{r}0.181 \\
(0.632)\end{array}$ & $\begin{array}{r}-0.078 \\
(0.559)\end{array}$ \\
\hline & & Electricity/gas & $\begin{array}{r}-0.122 \\
(0.550)\end{array}$ & $\begin{array}{l}-1.039 \\
(0.448)^{* * *}\end{array}$ & $\begin{array}{l}-1.274 \\
(0.529)^{* * *}\end{array}$ & $\begin{array}{r}0.141 \\
(0.502)\end{array}$ & $\begin{array}{r}0.733 \\
(0.503)\end{array}$ & $\begin{array}{l}1.024 \\
(0.431)^{* * *}\end{array}$ & $\begin{array}{r}-0.593 \\
(0.544)\end{array}$ & $\begin{array}{l}1.406 \\
(0.659)^{* * *}\end{array}$ & $\begin{array}{r}0.825 \\
(0.866)\end{array}$ & $\begin{array}{l}1.861 \\
(0.691)^{* * * *}\end{array}$ & $\begin{array}{r}0.940 \\
(0.824)\end{array}$ & $\begin{array}{l}2.867 \\
(0.685)^{* * * *}\end{array}$ & $\begin{array}{r}1.333 \\
(0.824)\end{array}$ & $\begin{array}{r}0.284 \\
(0.711)\end{array}$ & $\begin{array}{r}0.600 \\
(0.625)\end{array}$ \\
\hline & & $\begin{array}{l}\text { Communication/ } \\
\text { transportation }\end{array}$ & $\begin{array}{r}-0.450 \\
(0.403)\end{array}$ & $\begin{array}{r}-0.466 \\
(0.413)\end{array}$ & $\begin{array}{r}-0.676 \\
(0.519)\end{array}$ & $\begin{array}{r}-0.210 \\
(0.479)\end{array}$ & $\begin{array}{r}0.574 \\
(0.520)\end{array}$ & $\begin{array}{l}0.904 \\
(0.389)^{* * *}\end{array}$ & $\begin{array}{r}-0.317 \\
(0.440)\end{array}$ & $\begin{array}{l}1.246 \\
(0.559)^{* * *}\end{array}$ & $\begin{array}{r}0.157 \\
(0.783)\end{array}$ & $\begin{array}{r}0.886 \\
(0.591)\end{array}$ & $\begin{array}{r}0.829 \\
(0.745)\end{array}$ & $\begin{array}{l}1.919 \\
(0.662)^{* * * *}\end{array}$ & $\begin{array}{l}1.794 \\
(0.785)^{* * *}\end{array}$ & $\begin{array}{r}0.536 \\
(0.661)\end{array}$ & $\begin{array}{c}0.429 \\
(0.590)\end{array}$ \\
\hline & & $\begin{array}{c}\text { Wholesale/ retail/ } \\
\text { restaurants }\end{array}$ & $\begin{array}{c}-0.810 \\
(0.473)^{*}\end{array}$ & $\begin{array}{r}-0.784 \\
(0.564)\end{array}$ & $\begin{array}{l}-1.481 \\
(0.552)^{* * * *}\end{array}$ & $\begin{array}{c}0.342 \\
(0.517)\end{array}$ & $\begin{array}{r}0.277 \\
(0.527)\end{array}$ & $\begin{array}{l}1.085 \\
(0.428)^{* * *}\end{array}$ & $\begin{array}{c}-0.923 \\
(0.491)^{*}\end{array}$ & $\begin{array}{c}0.117 \\
(0.596)\end{array}$ & $\begin{array}{c}0.712 \\
(0.828)\end{array}$ & $\begin{array}{r}0.401 \\
(0.634)\end{array}$ & $\begin{array}{r}-0.097 \\
(0.736)\end{array}$ & $\begin{array}{l}2.459 \\
(0.719)^{* * * *}\end{array}$ & $\begin{array}{c}0.584 \\
(0.822)\end{array}$ & $\begin{array}{r}0.193 \\
(0.712)\end{array}$ & $\begin{array}{r}0.345 \\
(0.648)\end{array}$ \\
\hline & & Finance/ insurance & $\begin{array}{r}-0.165 \\
(0.537)\end{array}$ & $\begin{array}{c}-0.973 \\
(0.530)^{*}\end{array}$ & $\begin{array}{l}-1.332 \\
(0.561)^{* * *}\end{array}$ & $\begin{array}{r}0.855 \\
(0.525)\end{array}$ & $\begin{array}{r}0.176 \\
(0.533)\end{array}$ & $\begin{array}{r}0.266 \\
(0.407)\end{array}$ & $\begin{array}{r}0.014 \\
(0.444)\end{array}$ & $\begin{array}{l}1.066 \\
(0.576)^{*}\end{array}$ & $\begin{array}{r}0.548 \\
(0.858)\end{array}$ & $\begin{array}{l}1.197 \\
(0.667)^{*}\end{array}$ & $\begin{array}{r}0.636 \\
(0.808)\end{array}$ & $\begin{array}{c}0.602 \\
(0.640)\end{array}$ & $\begin{array}{r}-0.693 \\
(0.792)\end{array}$ & $\begin{array}{r}-1.090 \\
(0.724)\end{array}$ & $\begin{array}{r}0.229 \\
(0.715)\end{array}$ \\
\hline & & Real estate & $\begin{array}{c}-0.747 \\
(0.440)^{*}\end{array}$ & $\begin{array}{l}-1.185 \\
(0.408)^{* * * *}\end{array}$ & $\begin{array}{l}-1.383 \\
(0.464)^{* * * *}\end{array}$ & $\begin{array}{r}-0.327 \\
(0.441)\end{array}$ & $\begin{array}{r}-0.045 \\
(0.478)\end{array}$ & $\begin{array}{l}0.884 \\
(0.409)^{* *}\end{array}$ & $\begin{array}{r}-0.686 \\
(0.452)\end{array}$ & $\begin{array}{r}0.716 \\
(0.597)\end{array}$ & $\begin{array}{r}0.892 \\
(0.803)\end{array}$ & $\begin{array}{l}1.517 \\
(0.607)^{* * *}\end{array}$ & $\begin{array}{c}0.276 \\
(0.740)\end{array}$ & $\begin{array}{c}1.192 \\
(0.668)^{*}\end{array}$ & $\begin{array}{r}-0.144 \\
(0.803)\end{array}$ & $\begin{array}{r}-1.059 \\
(0.728)\end{array}$ & $\begin{array}{r}-0.620 \\
(0.672)\end{array}$ \\
\hline & & Service & $\begin{array}{l}-0.755 \\
(0.322)^{* * *}\end{array}$ & $\begin{array}{r}-0.304 \\
(0.351)\end{array}$ & $\begin{array}{l}-1.188 \\
(0.428)^{* * *}\end{array}$ & $\begin{array}{r}0.006 \\
(0.401)\end{array}$ & $\begin{array}{r}0.204 \\
(0.441)\end{array}$ & $\begin{array}{l}0.728 \\
(0.350)^{* * *}\end{array}$ & $\begin{array}{c}-0.733 \\
(0.408)^{*}\end{array}$ & $\begin{array}{r}0.498 \\
(0.515)\end{array}$ & $\begin{array}{r}0.157 \\
(0.740)\end{array}$ & $\begin{array}{r}0.824 \\
(0.540)\end{array}$ & $\begin{array}{r}0.699 \\
(0.690)\end{array}$ & $\begin{array}{l}2.192 \\
(0.606)^{* * * *}\end{array}$ & $\begin{array}{r}0.182 \\
(0.757)\end{array}$ & $\begin{array}{r}0.138 \\
(0.658)\end{array}$ & $\begin{array}{r}-0.256 \\
(0.582)\end{array}$ \\
\hline \multirow{7}{*}{ 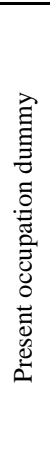 } & \multirow{7}{*}{ 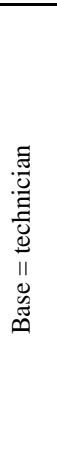 } & Manager & $\begin{array}{c}0.249 \\
(0.212)\end{array}$ & $\begin{array}{c}0.165 \\
(0.196)\end{array}$ & $\begin{array}{l}-0.462 \\
(0.180)^{* * *}\end{array}$ & $\begin{array}{c}0.012 \\
(0.163)\end{array}$ & $\begin{array}{c}0.247 \\
(0.160)\end{array}$ & $\begin{array}{c}0.033 \\
(0.149)\end{array}$ & $\begin{array}{r}-0.110 \\
(0.155)\end{array}$ & $\begin{array}{r}-0.165 \\
(0.204)\end{array}$ & $\begin{array}{r}-0.200 \\
(0.202)\end{array}$ & $\begin{array}{r}-0.057 \\
(0.179)\end{array}$ & $\begin{array}{c}0.009 \\
(0.191)\end{array}$ & $\begin{array}{l}0.331 \\
(0.193)^{*}\end{array}$ & $\begin{array}{r}-0.135 \\
(0.200)\end{array}$ & $\begin{array}{r}-0.041 \\
(0.204)\end{array}$ & $\begin{array}{c}0.018 \\
(0.194)\end{array}$ \\
\hline & & Administration & $\begin{array}{r}-0.223 \\
(0.224)\end{array}$ & $\begin{array}{r}-0.079 \\
(0.198)\end{array}$ & $\begin{array}{l}-0.921 \\
(0.198)^{* * * *}\end{array}$ & $\begin{array}{r}-0.302 \\
(0.185)\end{array}$ & $\begin{array}{r}-0.111 \\
(0.172)\end{array}$ & $\begin{array}{r}-0.086 \\
(0.163)\end{array}$ & $\begin{array}{l}-0.427 \\
(0.167)^{* *}\end{array}$ & $\begin{array}{l}-0.489 \\
(0.212)^{* * *}\end{array}$ & $\begin{array}{r}-0.284 \\
(0.228)\end{array}$ & $\begin{array}{r}-0.179 \\
(0.201)\end{array}$ & $\begin{array}{r}-0.043 \\
(0.211)\end{array}$ & $\begin{array}{r}-0.074 \\
(0.198)\end{array}$ & $\begin{array}{l}-0.540 \\
(0.212)^{* *}\end{array}$ & $\begin{array}{r}-0.048 \\
(0.218)\end{array}$ & $\begin{array}{r}-0.136 \\
(0.204)\end{array}$ \\
\hline & & Sales & $\begin{array}{l}-0.838 \\
(0.479)^{*}\end{array}$ & $\begin{array}{r}-0.032 \\
(0.461)\end{array}$ & $\begin{array}{r}0.111 \\
(0.355)\end{array}$ & $\begin{array}{c}0.148 \\
(0.290)\end{array}$ & $\begin{array}{r}0.295 \\
(0.251)\end{array}$ & $\begin{array}{r}-0.092 \\
(0.301)\end{array}$ & $\begin{array}{r}-0.057 \\
(0.330)\end{array}$ & $\begin{array}{r}-0.247 \\
(0.372)\end{array}$ & $\begin{array}{r}-0.539 \\
(0.371)\end{array}$ & $\begin{array}{r}-0.349 \\
(0.422)\end{array}$ & $\begin{array}{c}0.565 \\
(0.420)\end{array}$ & $\begin{array}{r}0.189 \\
(0.338)\end{array}$ & $\begin{array}{r}-0.494 \\
(0.394)\end{array}$ & $\begin{array}{r}-0.555 \\
(0.390)\end{array}$ & $\begin{array}{r}0.015 \\
(0.403)\end{array}$ \\
\hline & & Service & $\begin{array}{r}0.521 \\
(0.481)\end{array}$ & $\begin{array}{r}-0.471 \\
(0.393)\end{array}$ & $\begin{array}{l}-0.819 \\
(0.338)^{* * *}\end{array}$ & $\begin{array}{l}0.456 \\
(0.272)^{*}\end{array}$ & $\begin{array}{l}0.969 \\
(0.288)^{* * * *}\end{array}$ & $\begin{array}{r}-0.172 \\
(0.367)\end{array}$ & $\begin{array}{l}0.658 \\
(0.336)^{*}\end{array}$ & $\begin{array}{r}-0.300 \\
(0.458)\end{array}$ & $\begin{array}{l}-1.263 \\
(0.420)^{* * * *}\end{array}$ & $\begin{array}{l}-2.020 \\
(0.415)^{* * * *}\end{array}$ & $\begin{array}{l}-1.577 \\
(0.433)^{* * * *}\end{array}$ & $\begin{array}{r}-0.393 \\
(0.425)\end{array}$ & $\begin{array}{r}-0.527 \\
(0.537)\end{array}$ & $\begin{array}{r}-0.782 \\
(0.477)\end{array}$ & $\begin{array}{l}1.004 \\
(0.469)^{* * *}\end{array}$ \\
\hline & & $\begin{array}{c}\text { Communication/ } \\
\text { transportation }\end{array}$ & $\begin{array}{r}-0.203 \\
(0.768)\end{array}$ & $\begin{array}{r}0.107 \\
(0.469)\end{array}$ & $\begin{array}{r}0.135 \\
(0.475)\end{array}$ & $\begin{array}{c}0.434 \\
(0.508)\end{array}$ & $\begin{array}{c}0.031 \\
(0.440)\end{array}$ & $\begin{array}{l}1.543 \\
(0.448)^{* * * *}\end{array}$ & $\begin{array}{r}-0.350 \\
(0.392)\end{array}$ & $\begin{array}{l}-1.505 \\
(0.507)^{* * * *}\end{array}$ & $\begin{array}{r}-0.773 \\
(0.554)\end{array}$ & $\begin{array}{l}-1.894 \\
(0.618)^{* * * *}\end{array}$ & $\begin{array}{c}-1.166 \\
(0.467)^{* * *}\end{array}$ & $\begin{array}{c}0.892 \\
(0.711)\end{array}$ & $\begin{array}{l}-1.219 \\
(0.406)^{* * * *}\end{array}$ & $\begin{array}{r}-0.139 \\
(0.723)\end{array}$ & $\begin{array}{l}1.036 \\
(0.486)^{* * *}\end{array}$ \\
\hline & & Production & $\begin{array}{l}-0.954 \\
(0.403)^{* * *}\end{array}$ & $\begin{array}{r}0.254 \\
(0.218)\end{array}$ & $\begin{array}{r}-0.131 \\
(0.204)\end{array}$ & $\begin{array}{r}-0.163 \\
(0.169)\end{array}$ & $\begin{array}{r}0.093 \\
(0.169)\end{array}$ & $\begin{array}{l}0.384 \\
(0.168)^{* * *}\end{array}$ & $\begin{array}{c}-0.403 \\
(0.171)^{* * *}\end{array}$ & $\begin{array}{c}-0.441 \\
(0.216)^{* * *}\end{array}$ & $\begin{array}{l}-0.590 \\
(0.234)^{* * *}\end{array}$ & $\begin{array}{r}0.016 \\
(0.185)\end{array}$ & $\begin{array}{c}-0.713 \\
(0.197)^{* * * *}\end{array}$ & $\begin{array}{r}0.117 \\
(0.211)\end{array}$ & $\begin{array}{r}0.101 \\
(0.232)\end{array}$ & $\begin{array}{r}0.256 \\
(0.235)\end{array}$ & $\begin{array}{l}0.602 \\
(0.223)^{* * * *}\end{array}$ \\
\hline & & Others & $\begin{array}{r}0.051 \\
(0.235) \\
\end{array}$ & $\begin{array}{l}1.105 \\
(0.393)^{* * * *}\end{array}$ & $\begin{array}{c}-0.788 \\
(0.345)^{* * *} \\
\end{array}$ & $\begin{array}{r}-0.537 \\
(0.282)^{*} \\
\end{array}$ & $\begin{array}{r}-0.314 \\
(0.331) \\
\end{array}$ & $\begin{array}{r}-0.459 \\
(0.295) \\
\end{array}$ & $\begin{array}{c}-0.753 \\
(0.297)^{* *} \\
\end{array}$ & $\begin{array}{c}0.767 \\
(0.457)^{*} \\
\end{array}$ & $\begin{array}{c}-0.972 \\
(0.385)^{* * *} \\
\end{array}$ & $\begin{array}{r}-0.443 \\
(0.522) \\
\end{array}$ & $\begin{array}{r}0.539 \\
(0.515) \\
\end{array}$ & $\begin{array}{r}0.255 \\
(0.576) \\
\end{array}$ & $\begin{array}{c}0.433 \\
(0.756) \\
\end{array}$ & $\begin{array}{l}1.782 \\
(0.648)^{* * * *}\end{array}$ & $\begin{array}{r}-0.685 \\
(0.441) \\
\end{array}$ \\
\hline \multirow{5}{*}{ 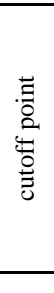 } & & $\mathrm{TAU}_{30}$ & $\begin{array}{l}-5.630 \\
(1.116)^{* * * *}\end{array}$ & $\begin{array}{c}-2.297 \\
(1.078)^{* * *}\end{array}$ & $\begin{array}{l}-6.150 \\
(1.135) * * * *\end{array}$ & $\begin{array}{l}-4.266 \\
(0.929)^{* * * *}\end{array}$ & $\begin{array}{c}-2.335 \\
(0.954)^{* * *}\end{array}$ & $\begin{array}{c}-0.543 \\
-0.939\end{array}$ & $\begin{array}{l}-3.606 \\
(1.050)^{* * * *}\end{array}$ & $\begin{array}{c}-0.214 \\
-1.259\end{array}$ & $\begin{array}{l}-3.650 \\
(1.416)^{* * * *}\end{array}$ & $\begin{array}{c}-0.650 \\
-1.219\end{array}$ & $\begin{array}{c}-1.562 \\
-1.391\end{array}$ & $\begin{array}{c}-2.311 \\
(1.352)^{*}\end{array}$ & $\begin{array}{c}-3.910 \\
(1.521)^{* *}\end{array}$ & $\begin{array}{c}-0.263 \\
-1.426\end{array}$ & $\begin{array}{l}-4.195 \\
(1.488)^{* * * *}\end{array}$ \\
\hline & & $\mathrm{TAU}_{15}$ & $\begin{array}{l}-4.150 \\
(1.107)^{* * * *}\end{array}$ & $\begin{array}{r}-0.811 \\
(1.072)\end{array}$ & $\begin{array}{l}-4.619 \\
(1.130)^{* * * *}\end{array}$ & $\begin{array}{l}-2.951 \\
(0.925)^{* * * *}\end{array}$ & $\begin{array}{r}-1.159 \\
(0.951)\end{array}$ & $\begin{array}{r}0.564 \\
(0.938)\end{array}$ & $\begin{array}{l}-2.450 \\
(1.048)^{* *}\end{array}$ & $\begin{array}{r}0.746 \\
(1.258)\end{array}$ & $\begin{array}{c}-2.456 \\
(1.415)^{*}\end{array}$ & $\begin{array}{c}0.750 \\
(1.219)\end{array}$ & $\begin{array}{r}-0.568 \\
(1.390)\end{array}$ & $\begin{array}{r}-1.323 \\
(1.352)\end{array}$ & $\begin{array}{c}-3.010 \\
(1.520)^{* * *}\end{array}$ & $\begin{array}{r}0.606 \\
(1.427)\end{array}$ & $\begin{array}{c}-2.877 \\
(1.487)^{*}\end{array}$ \\
\hline & & $\mathrm{TAU}_{0}$ & $\begin{array}{c}2.145 \\
(1.103)^{*}\end{array}$ & $\begin{array}{l}5.476 \\
(1.081)^{* * * *}\end{array}$ & $\begin{array}{r}1.739 \\
(1.120)\end{array}$ & $\begin{array}{l}3.373 \\
(0.925)^{* * * *}\end{array}$ & $\begin{array}{l}5.391 \\
(0.958)^{* * * *}\end{array}$ & $\begin{array}{l}7.021 \\
(0.951)^{* * * *}\end{array}$ & $\begin{array}{l}4.149 \\
(1.049)^{* * * *}\end{array}$ & $\begin{array}{l}8.777 \\
(1.284)^{* * * *}\end{array}$ & $\begin{array}{l}5.880 \\
(1.415)^{* * * *}\end{array}$ & $\begin{array}{l}9.351 \\
(1.237)^{* * * *}\end{array}$ & $\begin{array}{l}7.726 \\
(1.404)^{* * * *}\end{array}$ & $\begin{array}{l}6.796 \\
(1.356)^{* * * *}\end{array}$ & $\begin{array}{l}5.768 \\
(1.515)^{* * * *}\end{array}$ & $\begin{array}{l}8.794 \\
(1.438)^{* * * *}\end{array}$ & $\begin{array}{l}5.253 \\
(1.483)^{* * * *}\end{array}$ \\
\hline & & $\mathrm{TAU}_{-15}$ & $\begin{array}{l}4.243 \\
(1.116)^{* * * *}\end{array}$ & $\begin{array}{l}8.162 \\
(1.108)^{* * * *}\end{array}$ & $\begin{array}{l}4.093 \\
(1.136)^{* * *}\end{array}$ & $\begin{array}{l}6.022 \\
(0.950)^{* * * *}\end{array}$ & $\begin{array}{l}7.546 \\
(0.973)^{* * * *}\end{array}$ & $\begin{array}{l}9.605 \\
(0.975)^{* * * *}\end{array}$ & $\begin{array}{l}6.083 \\
(1.060)^{* * * *}\end{array}$ & $\begin{array}{c}10.257 \\
(1.303)^{* * * *}\end{array}$ & $\begin{array}{l}7.882 \\
(1.453)^{* * * *}\end{array}$ & $\begin{array}{l}11.118 \\
(1.25)^{* * * *}\end{array}$ & $\begin{array}{l}9.615 \\
(1.427)^{* * * *}\end{array}$ & $\begin{array}{l}8.646 \\
(1.367)^{* * * *}\end{array}$ & $\begin{array}{l}7.110 \\
(1.529)^{* * * *}\end{array}$ & $\begin{array}{c}10.173 \\
\left(1.4511^{* * * *}\right.\end{array}$ & $\begin{array}{l}7.247 \\
(1.500)^{* * * *}\end{array}$ \\
\hline & \multicolumn{2}{|c|}{ Observations } & 2483 & 3145 & 3304 & 4327 & 4841 & 5020 & 4828 & 4526 & 4141 & 4629 & 5070 & 4446 & 5059 & 4110 & 4547 \\
\hline
\end{tabular}

Standard errors in parentheses

$*^{* *} p<0.01, * * p<0.05, * p<0.1$ 